\title{
EXPLORING THE EFFICACY OF THE COMMUNITY ORGANIZATION HEALTH MODEL AS A TOOL FOR EVALUATING SPORT-FOR-DEVELOPMENT PROGRAMS: A QUALITATIVE CONTENT ANALYSIS OF THREE MODEL PROGRAMS
}

\author{
A Thesis \\ Presented to \\ The Faculty of California Polytechnic State University, \\ San Luis Obispo
}

\author{
In partial fulfillment \\ of the Requirements for the Degree \\ Master of Science in Kinesiology
}

By

Lauren Faye Denman

February 2013 
(C) 2013

Lauren Faye Denman

ALL RIGHTS RESERVED 
TITLE:

AUTHOR:

DATE SUBMITTED:

COMMITTEE CO-CHAIR:

COMMITTEE CO-CHAIR:

COMMITTEE MEMBER:
Exploring the Efficacy of the Community Organization Health Model as a Tool for Evaluating Sport-for-Development Programs: A Qualitative Content Analysis of Three Model Programs

Lauren Faye Denman

February 2013

Camille O’Bryant, Ph.D.

David Hey, Ph.D.

Pat Hosegood Martin, Ed.D. 


\begin{abstract}
Exploring the Efficacy of the Community Organization Health Model as a Tool for Evaluating Sport-for-Development Programs:

A Qualitative Content Analysis of Three Model Programs
\end{abstract}

Lauren Faye Denman

The HIV/AIDS pandemic is currently one of the most pressing world-wide concerns regarding the health and well-being of our global population. Due to the lack of a cure, recent efforts have focused on prevention measures for the disease. HIV prevention, particularly with the youth population, has spawned creative programs, such as the use of sport as an educational tool to equip youth with the skills to avoid contracting HIV. Due to the potent effect sport-for-development efforts exhibit on both individual and cultural level change, it can be assumed that HIV prevention sport-fordevelopment programs are worth maintaining. Within the use of sport-for-development programs comes the problem under investigation: the need to establish a uniform method from which to evaluate HIV sport-for-development program effectiveness- specifically in regards to cultural relevance, level of community ownership, and sustainability through partnership resources. In order to address this problem, this analysis used qualitative content analysis to examine the promotional documents of three best practice footballfor-development organizations- Grassroot Soccer, Mathare Youth Sports Association, and WhizzKids United. The purpose was to determine whether the Community Organization Health Model (COHM) was reflected in the values promoted through each organization's electronic promotional material. The content analysis showed a strong qualitative presence of all six of the COHM tenets in the promotional documents, as well as a meaningful theme of expanding partnerships to enhance sustainability. These 
findings indicate that the tenets of the COHM are valued by best practice football-fordevelopment organizations, which presents the opportunity for this model to be used in creating an evaluation procedure able to bridge cultural differences in programs.

Keywords: HIV prevention, football, sport-for-development, evaluation 


\section{ACKNOWLEDGMENTS}

I would like to express a huge 'thank you' to my thesis committee- Dr. Camille O’Bryant, Dr. David Hey, and Dr. Pat Hosegood Martin. Each of these individuals played such a key role in my development. They helped me refine my skill as a professional researcher and teacher, but more importantly they mentored and coached me through developing the leadership skills and knowledge it took to get me to this place. I am very grateful for the hours that they spent sacrificing to guide me and review continuously late drafts and reiterations of this project. Their patience and encouragement provided me with the ability to make mistakes and keep moving forward. I want to express gratitude to the friends and family who experienced me “disappearing" for a good year and a half but remained willing to stand by me providing encouragement and laughter through the long hours of writing (and writer's block). I also could not have made it through without my wonderful fiancé, who made dinner after dinner for me, even though he was working long hours to finish his graduate degree as well.

Finally, a special 'thank you' to all of my fellow graduate students and professors who did not serve a consulting role on this project. My graduate experience would not have been the same without comrades to commiserate with and additional mentors to keep me level headed and focused on the next step in the journey. 


\section{TABLE OF CONTENTS}

Page

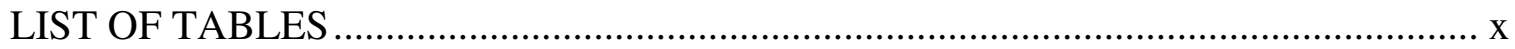

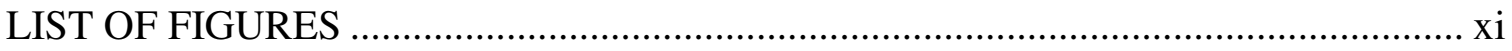

Chapter

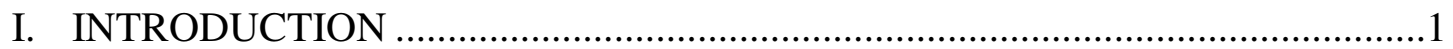

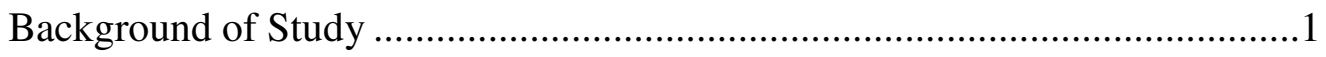

Statement of Problem.............................................................................6

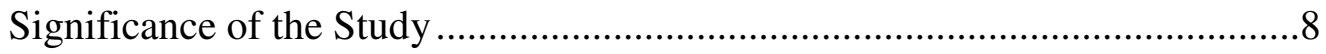

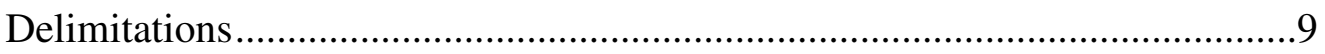

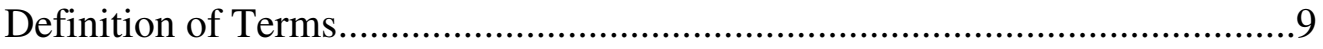

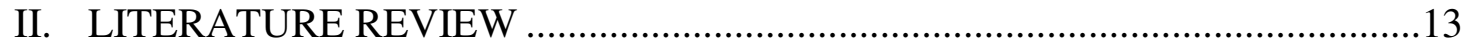

History and Impact of Human Immunodeficiency Virus (HIV) and Acquired Immunodeficiency Syndrome (AIDS) .................................13

HIV/AIDS in youth ......................................................................... 14

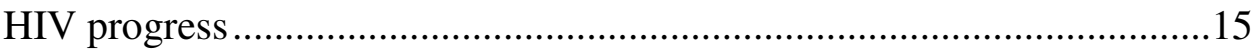

HIV progress: What works in engaging youth?...............................16

HIV, Youth and Cultural Change: A Possible Solution in Sport-for

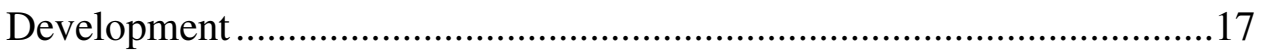

Sport, cultural relevance and community ownership...........................20

Football: A Culturally Relevant Sport for Africa and HIV .........................21

Football-for-development and program sustainability: A global

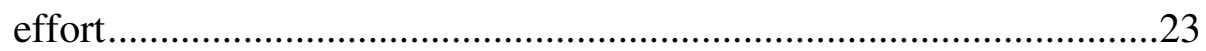

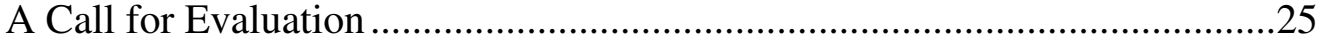

The Community Organization Health Model ............................................29

Using health models to create evaluation ..........................................29

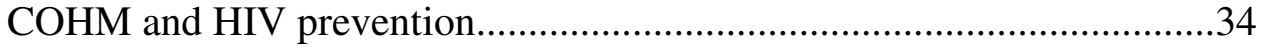

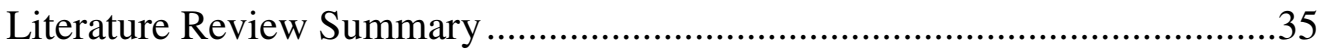

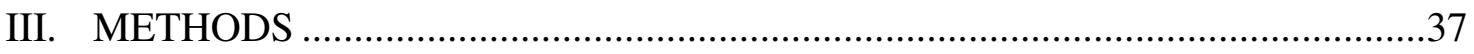

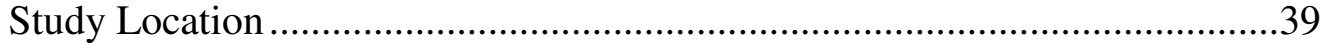


$\begin{array}{lll}\text { Chapter } & \text { Page }\end{array}$

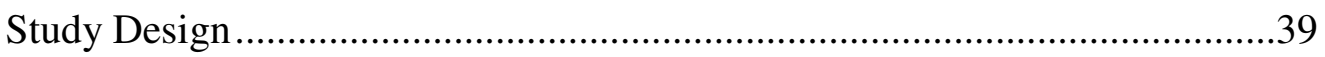

Methods for examining documents: Contents analysis .........................39

Programs and criteria for inclusion...................................................41

Organizations meeting inclusion criteria .......................................43

Data Collection .................................................................................44

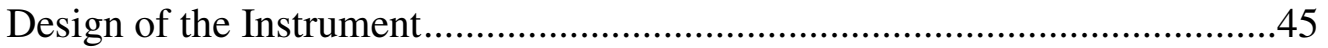

Establishing reliability of codebook ...................................................49

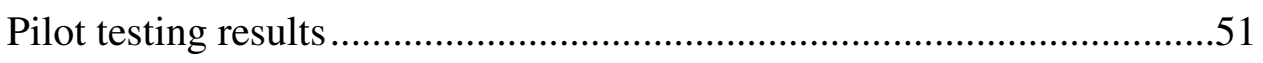

Final codebook reliability results .....................................................53

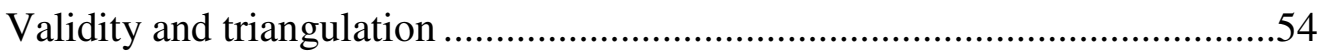

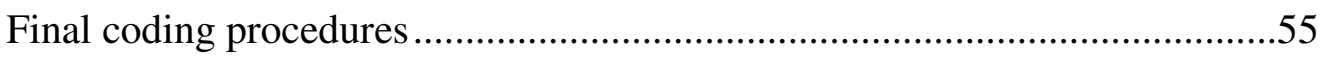

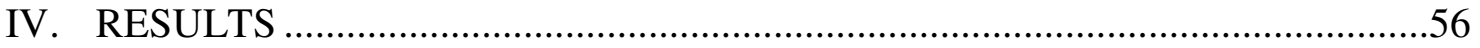

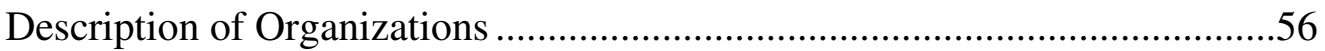

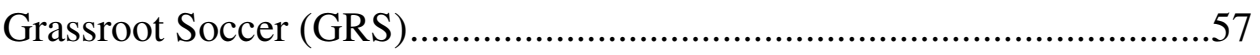

Mathare Youth Sports Association (MYSA) ........................................58

WhizzKids United (WKU) ............................................................59

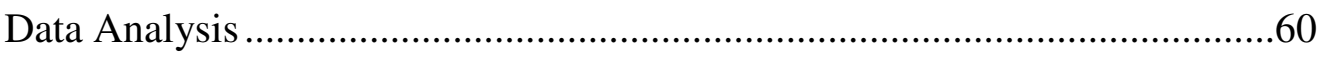

Research Question \#1: Presence of the COHM Tenets ................................61

Quantitative presence of individual COHM tenets ...............................61

Qualitative reflection of COHM tenets ..............................................64

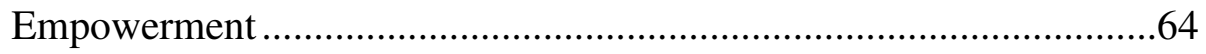

Critical Consciousness .................................................................68

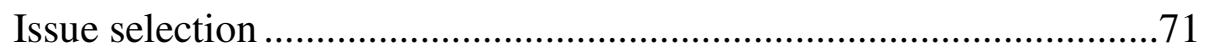

Social Capital ..................................................................... 73

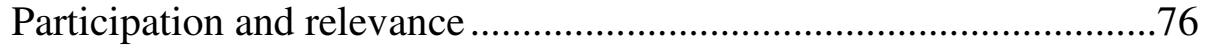

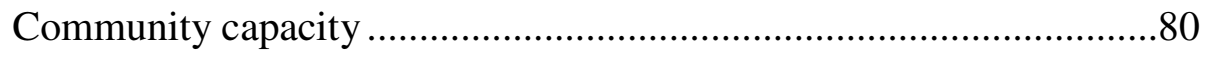

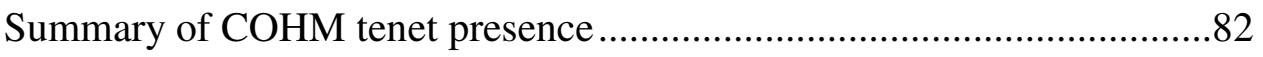

Additional theme: Enhanced partnership for sustainability....................82 


\section{TABLE OF CONTENTS (continued)}

Chapter

Research Questions \#2-4: The COHM Tenets and Recommendations

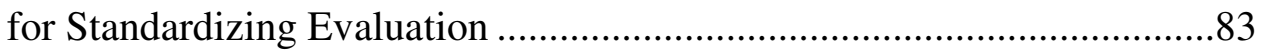

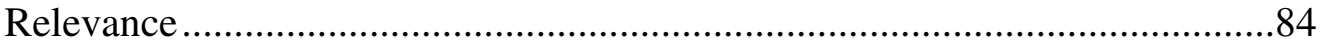

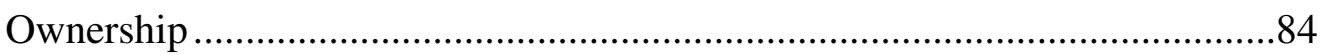

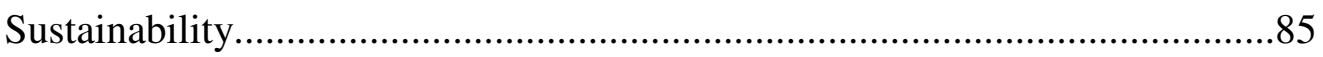

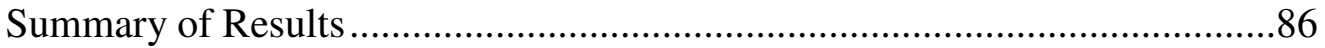

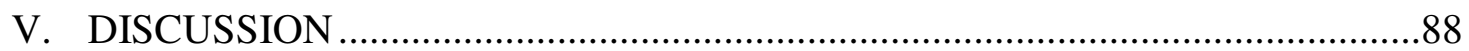

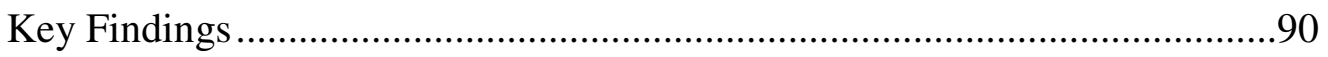

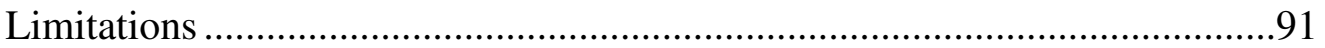

Practical Implications for Findings ......................................................93

Recommendations for Future Research ...................................................99

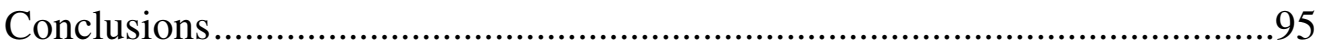

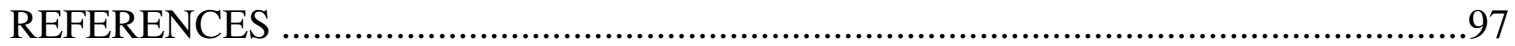

APPENDICES

A Process for Developing a Content Analysis............................................... 105

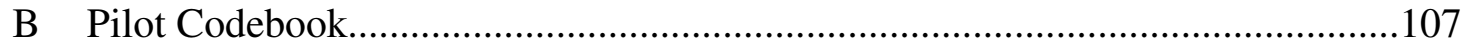

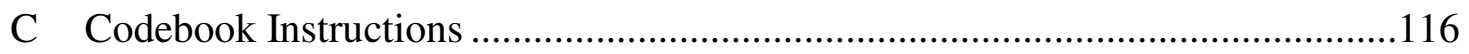

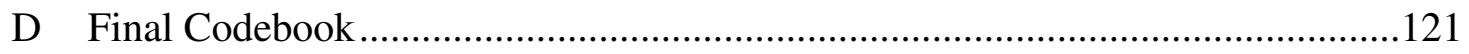




\section{LIST OF TABLES}

Table

Page

1. Football-for-Development Organizations Meeting Inclusionary

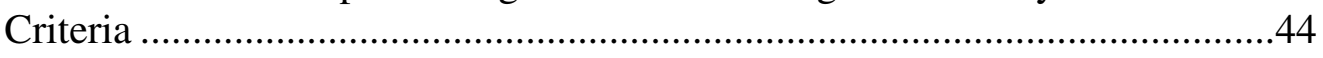

2. Pilot Subcategories Created From A Priori Evaluation of Data .....................48

3. Presence of the Community Organization Health Model (COHM)

Tenets Across Type of Document and Organization ......................................61

4. Percent of Documents Coded in Each Main Category …..............................62

5. Number of Codes for Each COHM Tenet .................................................64 


\section{LIST OF FIGURES}

Figure Page

1. The Community Organization Health Model (COHM) Tenets .......................31

2. Percent Presence of Individual COHM Tenets ...........................................63

3. Percent Presence of Partnership Code Compared to the COHM Tenets .........83

4. Percent of Coded Documents Reflecting Areas of Recommended

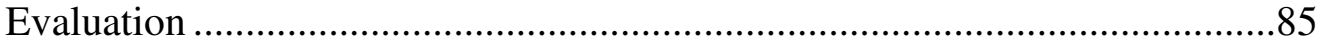




\section{Chapter 1}

\section{Introduction}

\section{Background of Study}

The impact of the human immunodeficiency virus (HIV). In the last three decades, international public health officials have directed their attention toward one primary health concern: the human immunodeficiency virus (HIV) pandemic. Since its introduction to the global community in 1981, medical practitioners have diagnosed roughly 60 million people as HIV positive, 25 million of whom have died from the virus (UNAIDS, 2010; World Health Organization, 2011a). While prevalence of the HIV virus, and its corresponding disease Acquired Immunodeficiency Syndrome (AIDS), peaked in 1999, its enduring presence is still a significant problem for the global community- particularly in Sub-Saharan Africa, which currently houses two thirds of all HIV cases (UNAIDS, 2010; World Health Organization, 2011a).

HIV in youth. While doctors and researchers have made significant advancements in the treatment of HIV/AIDS, the World Health Organization (WHO) and the United Nations (UN) still recognize the need for an explicit focus on prevention efforts; specifically, in the population most susceptible and least likely to prevent transmission: children and adolescents (World Health Organization, 2011b). At a summit in 2011, the WHO and UNAIDS established a new Millennium Development Health Goal: By 2015, no child shall be born with HIV (World Health Organization, 2011b). This new goal paired with the fact that $40 \%$ of new cases come from individuals aged 15-24, "youth" in the eyes of the UN, has placed a distinct focus on HIV/AIDS in youth (Botcheva \& Huffman, 2004; UNAIDS, 2010). Reducing incidence and 
prevalence, the number of new cases and the total number of cases respectively, of HIV in the youth population is a lofty goal; currently, 2.5 million children are infected with the virus, with 370,000 new cases resulting in the last year alone (UNAIDS, 2010; World Health Organization, 2011a).

Despite these statistics, children and youth are unique in many senses; they are the most vulnerable to the danger of HIV/AIDS; yet, they offer a unique opportunity to change the social order and awareness in their communities (Botcheva \& Huffman, 2004; Human Rights Watch, 2005; Lindsey \& Banda, 2010). Children also exhibit a unique resilience not often seen in their adult counterparts (Lindsey \& Banda, 2010). For this reason, government and nongovernmental organizations (NGOs) have started to look toward interventions that uniquely engage youth in a more meaningful way.

\section{HIV in youth, possible solution: The sport-for-development movement.}

Sporting events, from the Olympics to schoolyard pick up matches, help to define and shape cultures worldwide. By nature, sporting events bring communities together for a shared experience. In addition to its ability to bring a community together, sport presents a number of other positive characteristics which have made the UN, multiple NGOs, national governments and the corporate sector take notice and consider its use as a development tool (Brunelli \& Parisi, 2011; Mintzberg, 2006). Sport, used for development, is defined as "the utilization of sport as a tool to foster personal and social improvements of those people and communities most in need of development" (Houlihan $\&$ White, 2002, p. 48).

The United Nation's Inter-Agency Task Force on Sport for Development and Peace, formed in 2003, initiated a study (2003) to examine the characteristics that make 
sport well suited for use as a development tool. The Task Force's findings summarized the following as the most valuable effects of sport on the individual:

1) it teaches discipline, confidence, leadership, tolerance, cooperation and respect,

2) it exhibits the value of effort and managing victory and defeat,

3) it increases physical health, as well as raises awareness and respect for the individual's body and the bodies around them,

4) it improves communication skills and more actively involves local community,

5) it helps provide normalcy and structure, and

6) it helps individual's understand their identity, break stereotypes and value diversity.

On a broader societal level, sport provides a site for symbolic public acts crosses boundaries and breaks cultural barriers (President's Council, 2006; United Nations, 2003). Due to recognition of the potential of sport as a developmental tool, the UN broadly promoted the use of sport across the global sector, including as a tool to promote the fulfillment of the UN's Millennium Development Goals (MDGs) (United Nations, 2003; 2006).

Given that the problem of HIV surrounds both individual decisions and cultural structure and barriers, sport offers the potential to address HIV prevention on multiple levels. Sport sociology and psychology research shows that sport can have a potent effect on a developing youth's character and decisions, including all of the above listed UN Task Force benefits (Bailey, 2005; President's Council, 2006; United Nations, 2003). In addition, studies examining factors that affect the initiation of sexual activity show that sport participation reduces sexual activity among reproductively mature youth, including 
a particularly potent delay in sexual activity among youth females (Kay, 2009; Laub, Somera, Gowen, \& Diaz, 1999).

The problem of sport-for-development. After roughly a decade of use within the developmental sector, the attention on sport-for-development programs has shifted away from promoting sport's potential to calling for a uniform method of evaluating program effectiveness (Coalter, 2009; Coalter \& Taylor, 2010c; Levermore, 2008). However, standardizing evaluation depends heavily upon the context and developmental focus for which sport is used (Right to Play, 2008; United Nations, 2003).

As stakeholders and partnership organizations consider future health development efforts, they are demanding a more rigorous evaluation of sport-for-development program efforts. Researchers and funders alike want to know whether these programs are truly a viable and valuable resource to keep supporting as a development tool. While sport-fordevelopment programs have not gone un-evaluated for the last decade, the research has often been program specific and qualitative in nature, making it difficult to substantiate claims of causality (Right to Play, 2008). Many of the benefits, claimed to be associated with the use of sport are psychological and social in nature, making them both direct and indirect outcomes of the context and social interaction occurring at the time.

Through evaluating the characteristics of current best practices, researchers highlight three important factors that have been inconsistent across past evaluations:

1) considering the cultural relevance of development and implementation efforts

2) evaluating local ownership and 
3) exploring ways to further utilize resources through sustainable partnerships (Brunelli \& Parisi, 2011; Coalter \& Taylor, 2010c; Levermore, 2008; Right to Play, 2008).

Programs evaluators have not consistently explored these three elements together, in evaluation, due to the lack of a comprehensive and relevant standardized model from which to compare intra and inter-organizational efforts (Comic Relief, 2007; Right to Play, 2008).

The importance of creating a uniform method of evaluation for sport-fordevelopment programs cannot be over-emphasized, particularly within the use of sportfor-development in addressing HIV. Currently, thirty five worldwide organizations are using sport-for-development measures to deliver HIV prevention programs. In the effort to continue mitigating the impact of HIV/AIDS, it is valuable to determine an evaluation procedure that will continue to garner support for these HIV sport-for-development programs.

\section{Solution to the problem of sport-for-development: Quantitative evaluation via}

the Community Organization Health Model. Within the field of public health

development, there has often been a challenge in quantifying the social and psychological benefits of a community health effort. The solution to this challenge has been to use health models/conceptual frameworks to create structured quantitative and qualitative evaluation measures that provide a well-rounded view of program efficacy (Glanz, Rimer \& Viswanath, 2008). Conceptual frameworks provide clarity and direction when evaluating the expected and actual outcomes of a program's implementation; however, 
for a health model's framework to be useful in creating evaluation tools, the program(s) in question should value and reflect the basic tenets of the model (Glanz et al., 2008).

Due to sport's positive social and psychological effect on both communities and individuals, the aims of this development tool seem to correspond well with the framework of the Community Organization Health Model (COHM). The COHM framework attempts to help groups identify common problems or goals, mobilize resources, and implement strategies for reaching their collective goals, including building valuable partnerships (Minkler \& Wallerstein, 2002). The COHM seeks to meet the community where it is, ensuring relevance of efforts, rather than imposing external priorities in development. Finally, the model emphasizes community ownership to encourage sustainability and maintain development progress (Minkler \& Wallerstein, 2002).

Given its natural focus on the grassroots community level, the COHM naturally addresses the three areas recommended for standardized evaluation: cultural relevance, local ownership and sustainability. In addition, its focus on the community and harnessing cultural change makes it an appropriate model from which to highlight and amplify the positive effects of sport on the community and individual.

\section{Statement of Problem}

Given the strong support of the sport-for-development movement and its apparent fit in addressing HIV in youth, this study functioned under the assumption that sport-fordevelopment is an effective and valuable tool for addressing HIV prevention. Within the use of sport-for-development programs comes the problem under investigation: the need to create a uniform evaluation method from which to evaluate HIV sport-for- 
development programs in regards to: 1) cultural relevance of the program, 2) community ownership and 3) sustainability through partnership resources.

Given this problem, the purpose of this exploratory analysis was to examine whether the COHM would be a feasible model from which to design a relevant evaluation procedure. In order to examine the fit of this model, the content of the promotional and evaluation documents (video transcripts, website promotional materials and program training materials) of three best practice, HIV prevention, sport-fordevelopment programs were evaluated to examine the extent to which the organizations mirrored the basic concepts of the COHM. The extent to which they embodied, or failed to embody, the COHM tenets was used to determine the applicability of the model for creating evaluation procedures that could be standardized across HIV sport-fordevelopment programs.

While looking for the presence of the COHM tenets, the best practice data were also examined for emerging patterns or theories better suited to creating evaluation procedures reflecting program relevance, ownership and sustainability. As such, the content analysis was performed with a qualitative set of procedures and addressed the following research questions:

1) To what extent do the three organizations in question convey, or fail to convey, the tenets of the COHM in their promotional and evaluation documents?

2) To what extent are the organizations establishing community ownership?

3) To what extent are the organizations establishing cultural relevance?

4) To what extent are the organizations establishing sustainability? 
Qualitative content analysis of the promotional and evaluation documents was used due to both the complexity of the problem and the exploratory nature of this analysis. The inherent social and cultural complexity of both the HIV disease and the impact of sport-for-development programs made a structuralism framework most appropriate for this study. Structuralism focuses on the social and physical institutions that help create meaning within the culture of local communities (Denzin \& Lincoln, 2000; Patton, 2002). Within this framework, the researcher approached the analysis with an interpretivist paradigm, which aimed not to verify whether the COHM was a truth (e.g., correct or incorrect hypothesis) but rather looked for emerging patterns that either confirmed the feasibility of using the COHM or offered recommendations of other best fit theories or models (Denzin \& Lincoln, 2000; Patton, 2002).

\section{Significance of the Study}

Due to the enduring presence of HIV worldwide, and the lack of a cure for the disease, world leaders have promoted a continued effort to refine effective prevention techniques. Non-governmental organizations (NGOs) and local leaders have continued to focus HIV prevention efforts toward youth, due both to the high prevalence within this age group and the fact that youth have the potential to create meaningful cultural change (Campbell, 2001; UNAIDS, 2010). However, in order to realign youth mentalities, HIV efforts must be addressed within the socio-cultural, economic and political realities of each individual culture (Coalter, 2010a, 2010b; United Nations, 2003).

Sport provides an avenue for gathering community together in meaningful discussions that can shape cultural, political and economic change. However, to grow sport as an HIV development tool in its fullest capacity requires the establishment of a 
relevant model from which multiple programs could be evaluated (Comic Relief, 2007;

Levermore, 2008; Right to Play, 2008). A uniform evaluation procedure, based upon this model, would provide additional credibility to programs, as well as enhance each program's ability to continue growing a sustainable presence in its local community. It is in addressing this evaluation problem that researchers can compare current program strengths, streamline the use of resources, and realize both local and international health development goals regarding the prevention of HIV.

\section{Delimitations}

Due to the researcher's location in San Luis Obispo, California, when undertaking this study, the scope of this analysis was limited to what was accessible via electronic communication from the organizations under study. Due to the physical separation from the programs, and the unique aspect of the evaluation problem, an evaluation of the actual efficacy of football-for-development programs was not within the scope of this analysis.

\section{Definition of Terms}

Acquired Immunodeficiency Syndrome (AIDS). An autoimmune disease, in which the progressive failure of the body's immune system causes opportunistic infections and cancers to thrive (World Health Organization, 2006).

Center for Disease Control $(C D C)$. A United States federal agency under the Department of Health and Human Services; it works to protect public safety and health through partnerships with various organizations (Center for Disease Control, 2011).

Critical Consciousness. A consciousness based on reflection and action in making change. One of the six tenets of the COHM (Minkler \& Wallerstein, 2002). 
Community Capacity. Community characteristics affecting its ability to identify, mobilize, and address problems. One of the six tenets of the COHM (Minkler \& Wallerstein, 2002).

Community Organization Health Model (COHM). A health theory model that seeks to change health behavior by helping local communities identify common problems or goals, mobilize resources, and implement strategies for reaching collective goals (Minkler \& Wallerstein, 2002).

Development. Process of enlarging peoples' choices and increasing opportunities available to all members of society (United Nations, 2003).

Empowerment. Social action process for people to gain mastery over their lives and the lives of their communities. One of the six tenets of the COHM (Minkler \& Wallerstein, 2002).

Federation Internationale de Football Association (FIFA). The international governing body for the sport of football. Its membership comprises 208 national associations (FIFA, 2011b).

The Global Fund. An organization created by a UN resolution to provide a funding source for prevention and treatment efforts for the world's top three most debilitating diseases- malaria, tuberculosis and HIV (The Global Fund, 2011).

Human Immunodeficiency Virus (HIV). A retrovirus that is the cause/source of Acquired Immune Deficiency Syndrome (World Health Organization, 2006).

Incidence (of a disease). The number of new cases during a certain time period (World Health Organization, 2012). 
Issue Selection. Identifying winnable and specific targets of change that unify and build community strength. One of the six tenets of the COHM (Minkler \& Wallerstein, 2002).

Non-government Organization (NGO). A term, originated by the UN, referring to organizations that do not form part of a government and are not conventional for-profit businesses (United Nations, 2011).

Participation and relevance. Community organizing should "start where the people are" and engage community members as equals. One of the six tenets of the COHM (Minkler \& Wallerstein, 2002).

“Plus sport” Programs. Development programs focused primarily around sport, utilize sport program in parallel with other development, but sport is the primary means through which development efforts are expressed (Coalter, 2008).

Prevalence (of a disease). The total number of cases present in a population at a given time of measurement or across a period of time (World Health Organization, 2012).

The (RED) Campaign. A part of The Global Fund containing awareness events, including special performances and World AIDS Day events, and business partnerships offered through Product (RED), where corporations create (RED) products to sell, one half of the proceeds going to The Global Fund ((RED), 2011b).

Social capital. Relationships between community members including trust, reciprocity and civic engagement. One of the six tenets of the COHM (Minkler \& Wallerstein, 2002). 
"Sport plus" Programs. Development programs that are currently functioning that utilize sport's popularity to attract young people to education/training (Coalter, 2008).

Sport. All forms of physical activity that contribute to physical fitness, mental well-being and social interaction (United Nations, 2003).

Sport-for-Development (SFD). The intentional use of sport, physical activity and play to attain specific development and peace objectives, including the Millennium Health Goals (Right to Play, 2008, p. 13).

United Nations $(U N)$. An international organization aimed at facilitating cooperation in international law, security, economic development, social progress, human rights and the achievement of world peace (United Nations, 2011).

World Health Organization (WHO). A specialized agency of the United Nations that acts as a coordinating authority on international public health (World Health Organization, 2012).

Youth. UN defines a youth as ranging from the ages of 15-24. Youth is generally considered a process of preparing young people to meet challenges which make them “socially, physically and cognitively competent" (United Nations, 2003, p. 6). 


\section{Chapter 2}

\section{Literature Review}

In the face of the HIV/AIDS pandemic, it is important to understand the way this disease influences the world's population and the current action that world leaders are taking to mitigate its impact (UNAIDS, 2010; World Health Organization, 2011b). Due to the lack of a cure, the most recent efforts have shifted away from treatment alone and toward prevention, particularly in the at risk youth population (Botcheva \& Huffman, 2004; UNAIDS, 2010; World Health Organization, 2011b). In focusing on youth, sport has been identified as a particularly relevant development tool, affecting both individual and cultural change (Brunelli \& Parisi, 2011; United Nations, 2003; 2006). However, no means of develop is without its own weaknesses; sport-for-development programs, while broadly promoted, have not been effectively tracked and evaluated (Levermore, 2008; Coalter, 2009). Therefore, it is important to understand the impact of HIV/AIDS, the effect of sport-for-development programs and the challenges in creating meaningful evaluations. Hence, the purpose of this review is to twofold; to confirm the proposed relevance of using sport as a development tool for HIV prevention and to elucidate a possible solution to the evaluation problem.

\section{History and Impact of the Human Immunodeficiency Virus (HIV) and Acquired Immunodeficiency Syndrome (AIDS)}

1981. The year in which the human immunodeficiency virus (HIV), and its corresponding syndrome acquired immunodeficiency syndrome (AIDS), made their first public appearance. When doctors initially discovered the virus in isolated populations, primary gay men and drug users, little was known about the way it functioned or the 
devastation it would cause (Rambaut, Posada, Crandall \& Holmes, 2004). In time, scientists determined the HIV virus was neither a contagion nor existing in isolated communities. Due to the general lack of knowledge about the pathology of the virus, HIV/AIDS had grown into a pandemic by the late 1990s (Rambaut et al., 2004; World Health Organization, 2006). Due to its complexity and rapid spread, HIV/AIDS quickly developed into one of the United Nations' (UN) primary focuses of concern- classified as a health concern that could only be dealt with through a coordinated effort (The Global Fund, 2011; World Health Organization, 2006).

Since its introduction to the global community, roughly 60 million people have been identified as HIV positive, and AIDS has claimed the lives of roughly 25 million (UNAIDS, 2010; World Health Organization, 2011a). When the disease peaked in 1999, the World Health Organization (WHO) initiated recurring summits to develop a comprehensive strategy for addressing prevention and treatment of HIV. These initial summits led to the development of the document now known as the Millennium Development Goals (MDGs). The MDGs, deemed to be of international importance, have shaped the UN and the WHO's efforts at creating partnerships with local governments and non-governmental organizations.

HIV/AIDS in youth. While doctors and researchers continue to make significant advancements in treating HIV/AIDS, the WHO and the UN have pushed for a strong focus on prevention; specifically, in the populations most susceptible: children and adolescents. At a summit in 2011, UNAIDS established a new Millennium Development Goal: By 2015, no child shall be born with HIV (World Health Organization, 2011b). 
This new goal, paired with the facts that 2.5 million children are currently infected with HIV and $40 \%$ of the new cases come from individuals aged 15-24, has placed a distinct focus on HIV/AIDS prevention in youth (Botcheva \& Huffman, 2004; UNAIDS, 2010; World Health Organization, 2011a). Within this youth population, females are at a greater risk of contracting the disease than males due to cultural norms and the opportunities afforded to them (UNAIDS, 2010; World Health Organization, 2011a). Children and youth are not only more susceptible to contracting the malady, but they often lose the last vestiges of childhood due to the burden of infected family members. Fewer and fewer of these children, impacted by HIV, are receiving a primary education. The need to take on adult responsibilities often limits not only the quality of their own health but the opportunities afforded to them to live a healthy life (Botcheva \& Huffman, 2004; Human Rights Watch, 2005).

HIV progress. Faced with these daunting statistics, it is often easy to overlook the progress world leaders have made in fighting HIV/AIDS. Past and current prevention and treatment efforts have successfully stabilized the pandemic, and in some cases, decreased the spread of the virus (World Health Organization, 2006). According to the UNAID's 2010 Global Report, HIV prevalence- the total number of cases in the population- decreased by over $25 \%$ in twenty two, high-risk African countries. Specifically, in regards to youth, there was a $24 \%$ drop in new cases developed by children from 2004-2009. The UN also reported a decrease of 19\% in HIV-related deaths in children, during this same time period. These improvements reflect a strong dedication to global partnerships, combining efforts from international organizations, 
grassroots NGOs and corporate awareness and contribution ((RED), 2011a; World Health Organization, 2011a).

The greater the effort the global community puts forth to stop the spread of HIV/AIDS to subsequent generations, the greater the possibility of substantially containing or eradicating the disease. In the effort to halt the progress of the disease, youth are a unique population; they offer an opportunity, during development and education, to not only protect themselves but to create a substantial change in the culture and awareness surrounding the disease (Botcheva \& Huffman, 2004; Human Rights Watch, 2005; Lindsey \& Banda, 2010). Youth also exhibit a unique resilience that is often not seen in their adult population counterparts (Lindsey \& Banda, 2010). For these reasons, world leaders have recognized that youth seem to be the best population to target in the aim to reverse the ride of HIV/AIDS.

HIV progress: What works in engaging youth? Due to nearly three decades of research into HIV prevention and treatment, researchers have identified certain pillars of HIV programming that make prevention programs most effective with youth. These four pillars include:

1) knowledge- built through a trusting relationship with coaches, teachers and peer role models,

2) life skills- built through the development of character and opportunities afforded to youth,

3) a safe environment- including physical and emotional safety, and

4) a supportive environment- to leave the stigma and discrimination that may be present outside of the HIV program and encourage discussions about the 
disease and culture surrounding it (Botcheva \& Huffman, 2004; United Nations, 2006).

For youth affected by HIV, a sense of normalcy and the opportunity to slow the process of maturation is often fleeting (Botcheva \& Huffman, 2004; Human Rights Watch, 2005). The opportunity to include disadvantaged children, in a structured HIV prevention and treatment program, allows all of the above mentioned goals to have the potential to come to fruition.

\section{HIV, Youth and Cultural Change: A Possible Solution in Sport-for-Development}

While a number of programs could encompass the previously mentioned characteristics, the avenue of sport possesses unique qualities that offer the potential to reach both youth and adults, as well as shape cultural change. Sport is a mainstay of societies worldwide. Stakeholders in sport have always acknowledged both the objective and subjective value of sport; however, in the early 2000s international leaders began recognizing sport's potential use as a tool for development purposes (Burnett \& Uys, 2000; Green, 2008).

Sport is defined as "all play, physical recreation, and sport that are freely chosen activities undertaken for pleasure" (United Nations, 2003, p. 12). Development is defined as "the process of enlarging people's choices and increasing opportunities available to all members of society" (Right to Play, 2008, p. 6). When these two elements are combined, it results in "the intentional use of sport, physical activity and play to attain specific development and peace objectives, including the Millennium Development Goals" (Right To Play, 2008, p. 12). 
Within all development work, it is critically important to unite the community and enlist active participation (Right to Play, 2008). Sport offers the possibility to achieve both. By nature, sport events bring community together on a variety of levels, bridging cultural divides and creating cooperation, tolerance, and respect (United Nations, 2003). The simple and enjoyable structure of sport also makes it particularly well suited for development efforts, especially when used with children or adolescents (Delva \& Temmermen, 2006; Mintzberg, 2006; Tobisch \& Preti, 2010).

Research within the sectors of sport sociology and sport psychology shows that sport can have a potent effect on a developing child's character and decisions (Bailey, 2005; President's Council, 2006). The UN's Task Force's evaluation of the use of sportfor-development programs highlighted the following characteristics as most valuable for youth:

1) teaching participants discipline, confidence, leadership, tolerance, cooperation and respect,

2) teaching the value of effort and learning how to manage both victory and defeat,

3) increasing physical health and in turn, increasing a child's awareness and respect for his/her body,

4) creating a greater awareness of the environment around them,

5) encouraging participation, that improves community involvement; offering normalcy and structure in uncertain environment, and 
6) encouraging the understanding of a child's identity, including challenging stereotypes and emphasizing the importance of diversity (Right to Play, 2008; United Nations, 2003; 2006).

All of the above mentioned characteristics not only encouraged NGOs to start incorporating sport into their development efforts, but led the UN to acknowledge the potential power of using sport as a standalone development tool, not just a supplement (Burnett \& Uys, 2000; Green, 2008; United Nations, 2003). To promote sport's use as a developmental tool, the UN dedicated an entire year, the 2005 International Year of Sport and Physical Education, to advocate and fund sport-for-development programs (United Nations, 2006). The UN, WHO and several corporate funders, set aside special funding to continue supporting existing programs and to encourage the development of new programs. During this time, sport-for-development efforts branched out to include efforts for:

1) conflict resolution and intercultural understanding,

2) building new physical and social infrastructures,

3) raising awareness through education,

4) empowering disadvantaged individuals through vocational training,

5) directly impacting physical and psychological health, and

6) economic development and poverty alleviation (Levermore, 2008; United Nations, 2006).

Furthermore, the UN recognized sport's potential for use to advance their Millennium Development Goals (MDGs) by: 
1) promoting education, gender equality, HIV awareness and reduction of physical disease,

2) being a cost effective solution that mobilizes society, leading to a greater chance of sustaining the program, and

3) instilling the value of activity at a young age thereby promoting healthy development of motor skills (Right to Play, 2008).

The involvement of numerous sectors in a coordinated and cohesive effort, during this International Year of Sport, led to new partnerships among international organizations, businesses, NGOs and local communities.

Sport, cultural relevance and community ownership. It is clear that sport exhibits a strong effect on society and culture in general. It provides an opportunity for both individual change and a site for symbolic public acts through its ability to gather large portions of the community (United Nations, 2006). Sport also possesses the distinct ability to cross cultural boundaries and break down existing barriers between different groups of individuals (Beutler, 2008; Brunelli \& Parisi, 2011). For individuals or groups marginalized in society, due to the fact that they are HIV positive, sport provides the opportunity to feel connected to the community (United Nations, 2003). However, sport's ability to cross cultural boundaries does not automatically ensure unity and connection. For programs to develop the positive characteristics of sport, there must be an intentional effort to make both the structure and implementation of these programs culturally relevant to the community and the effect of HIV in that community (Banda, Lindsey, Jeanes \& Kay, 2008; Brunelli \& Parisi, 2011; Coalter, 2009; Levermore, 2011; Locher, 2007). 
The most meaningful role models and coaches in sport programs are local heroes from the community (Botcheva \& Huffman, 2004; Banda et al., 2008). When youth watch older members of the community invest in a program, it increases the likelihood both of the youth participating and of the youth investing in program maintenance as they mature (Eley \& Kirk, 2002; Kay, 2009). Culturally relevant programs create not only sustainable programs but the potential for economic growth and job opportunities as these programs grow in nature (Coalter, 2009; United Nations, 2006). The involvement of the local community allows for the continued presence of these programs in Africa and increases the potential for change to take place within the culture surrounding HIV/AIDS (Coalter, 2009; Levermore, 2011; Locher, 2007).

\section{Football: A Culturally Relevant Sport for Africa and HIV}

It is clear that even within the use of sport, choosing a culturally relevant sport is critical to the success of sport-for-development programs addressing HIV/AIDS education. For those suffering from HIV in South American and African countries, football (soccer) is one of the most culturally relevant sports. It is estimated that football is the world's most popular sport, with roughly 240 million people who play on a regular basis (Mwaanga, 2010). Aside from simply the number of citizens engaging in the sport, the culture of football pervades formal and informal societal interactions. Aside from its universal popularity, football is uniquely suited as a key sport for development use, due to its simple nature, minimal equipment and potential for partnerships (Mwaanga, 2010, Vienna Institute for International Dialogue, 2011). Football is also a sport that involves more players than the average team sport, allowing for greater opportunity for 
participation. All of these characteristics combine to make football a cost effective and engaging sport with the capacity to reach a large population.

Due to football's international presence, it also offers a unique opportunity for partnerships with key international organizations, including football's international governing body, the Federation Internationale de Football Association or FIFA (FIFA, 2011b). FIFA's connections to corporate responsibility programs, such as Nike, Adidas and Puma, expand access to equipment, monetary and advocacy resources (FIFA, 2011b; Giardina, 2010; Nike CR Report, 2008). To funnel these resources to appropriate programs, FIFA created a partnership with a global football-for-development network called streetfootballworld (streetfootballworld, 2011). This partnership created a connection between local grassroots efforts, as coordinated by streetfootballworld, and international business corporations.

On a grassroots level, organizations within local communities have built sport infrastructures around football to enhance the availability of equipment, the dissemination of health information, and to allow for the creation of economic opportunities. For example, the Alive and Kicking program was designed to create jobs through the construction of a sport infrastructure that produces football equipment; however, their impact goes beyond providing jobs and equipment, as all of the balls produced by Alive and Kicking feature HIV information printed on the face of the football (Alive and Kicking, 2011; Right to Play, 2008). It is through the opportunities for international and local partnership and football's unique characteristics that make it a relevant sport for addressing HIV prevention. 
Football-for-development and program sustainability: A global effort. As is evidenced in the multitude of football partnership resources, partnerships are pivotal a piece in sustaining programs. Early UN summits, focused on creating action plans for HIV response, stressed the importance of international partnerships and cooperation to provide both an effective and sustainable answer to this problem (UNAIDS, 2010; World Health Organization, 2011b). These international partnerships included the melding of work from non-governmental organizations (NGOs), local governments, international peace organizations and corporate investment (Right to Play, 2008). Within this web of partnerships, international organizations such as the WHO, the UN, and the CDC seek to provide the structural framework for the large scale efforts, and individual NGOs create smaller, locally-focused efforts which allow for a closer partnership with local communities. Both NGOs and global authorities seek to encourage corporate responsibility and involvement in the sport-for-development effort (Banda et al., 2008; Beutler, 2008; FIFA, 2011a; The Global Fund, 2011; (RED), 2011a). Given that resource, monetary, knowledge-based and power, access is a large part of sustaining an effort, it merits a brief mention when discussing the value of partnerships.

In recent years, corporations have created a variety of ways to help fund HIV and sport-for-development efforts: the creation of the Global Fund and its (RED) Campaign, individual sport corporations' social responsibility efforts (e.g., Nike's Let Them Play, Puma's Corporate Responsibility), and innovative NGO fundraising efforts (Giardina, 2010; The Global Fund, 2011; Nike CR Report, 2008; (RED), 2011a). The growing corporate interest, and subsequent contribution, to the sport-for-development movement 
currently provides a large portion of the funding for ongoing efforts (Coalter, 2009; The Global Fund, 2011; Levermore, 2011).

Moving out of the business sector, a variety of other knowledge-based and advocacy opportunities arise from partnerships with international sport governing bodies, particularly FIFA, the Football for Hope program and the media exposure that can result from large sporting events such as the World Cup. In 2005, FIFA was one of the first sports federations to create an internal corporate social responsibility (CSR) department (FIFA, 2011b). The point of the CSR department was to dedicate .7\% of revenues to projects that helped support "the utilization of football in the achievement of the United Nation's MDGs” (FIFA, 2011b). Beyond simply providing corporate revenue, FIFA used the World Cup to help support grassroots organizations through advocacy, publicity and fundraising.

FIFA and the streetfootballworld network, in conjunction with South Africa's 2010 World Cup, worked to create the Football for Hope program. The goal of this program was to fund and construct twenty "Football for Hope Centers," which could serve as headquarters to best practice organizations across Africa (FIFA, 2011a). FIFA has used streetfootballworlds connection to local programs to identify the location and host organizations for each Football for Hope Center. All chosen organization seek to promote public health, including HIV prevention, and education through the use of football in disadvantaged communities. This program is meant to expand resource availability to best practice programs, better highlighting their efforts within the footballfor-development movement. 
Apart from its partnership with FIFA, streetfootballworld's original purpose was to provide a connection to programs utilizing football as a development tool. Its network currently connects over 80 organizations, in 50 different countries (streetfootballworld, 2011). Streetfootballworld's three primary objectives include:

1) partnership for advocacy work, to bring about social, economic and political change,

2) creation of clinics, conferences and meetings to share expertise and programmatic ideas, and

3) development of an electronic "Knowledge Center" where organizations can access best practice methods from sister organizations in the network (streetfootballworld, 2011).

It is clear, from the resources devoted to developing global football-fordevelopment networks, that international and local leaders alike recognize the value of partnership. Whether partnerships are used for financial resources, policy advocacy or the dissemination of valuable program best practice procedures, the value in creating a reciprocal partnership is not to be overlooked.

\section{A Call for Evaluation}

It seems clear that sport-for-development programs, specifically those utilizing football

, offer the potential to produce a substantial effect on both youth development and the impact of HIV in Africa. Football appears to be effective due to its cultural relevance, ability to create community buy-in and ability to create a myriad of partnerships that offer resources for sustainability. 
Due to all of the potential football-for-development offers, it seems appropriate that these programs begin to focus more effort on a way to uniformly evaluate program progress across cultural context. Indeed, sport-for-development stakeholders are requesting a more rigorous evaluation of program development and progress, to capitalize on the best areas to invest resources. Standardizing an evaluation method would serve to enhance partnerships in three ways:

1) it would reduce the influence of funders on the development and implementation of program objectives,

2) it would help organizations accurately evaluate the type of resource support they need from potential partners, and

3) it would continue to reinforce the benefit of using sport as a development tool for HIV prevention (Coalter, 2009; Comic Relief, 2007; Levermore, 2008; Right to Play, 2008).

Aside from financial stakeholders, academic researchers in the field of sport-fordevelopment also recommend that a uniform evaluation approach be developed to add legitimacy to the outcomes promoted by organizations. Sport-for-development initiatives are described as "still in their infancy, woefully underfunded, unregulated and isolated from mainstream development efforts" (Right to Play, 2008, p. 22) making it all the more imperative that rigorous backing is created to ensure the continued support of these programs. However, sport-for-development does not easily lend itself to a strictly quantitative evaluation, due to the need to understand cultural and behavioral change that evolves over time (Levermore, 2011). 
While a number of programs have met great success in providing culturally relevant programs, there still appears to be a number of sport-for-development programs that may be ignoring uncomfortable political and moral barriers to culture and community change (Coalter, 2009; Right to Play, 2008). Within the initiation of new programs and the local expansion of others, evaluation is often seen as another burden rather than an opportunity to examine the cultural effect and organizational growth opportunities (Levermore, 2011). Evaluation offers a good indicator of whether the organization truly understands the needs of the community. Even the broadly promoted MDG's can work against local organizations, if the community perceives the exchange of resources and time out of touch with their own local goals.

All development efforts need to focus on the community as the center of the approach in order to determine the correct allocation of resources (Coalter, 2010a). While international or nonlocal NGOs need to be aware of community needs, the community should also acknowledge the value of partnerships in addressing macro-level structural obstacles to change (Coalter \& Taylor, 2010c).

Due to the importance of evaluation procedures in addressing all of the above complexities, Levermore (2011), proposed that every organization, when discussing its implementation needs, address the following three questions:

1) Has evaluation of the program been undertaken?

2) If so, which method was used and was it conducted internally or externally?

3) How much of the results were made public?

Simply asking if evaluation has occurred seems like an obvious question, but evaluation procedures are often the last piece to be considered in planning and 
implementation (Coalter \& Taylor, 2010c). The method and design of evaluation can be indicative of the quality of the program. If the evaluation is performed internally, it is important that the staff member performing the evaluation is well trained in data and research methods, allowing for an unbiased and thorough evaluation (Levermore, 2008; Coalter \& Taylor, 2010c). External evaluation is always recommended, as it can occur via an individual that is not a stakeholder in the success of the program. In addition, researchers recommend that an external evaluator not be associated with a funding organization, to reduce potential stakeholder bias. Finally, the last question addresses the willingness of an organization to make their findings, regarding program effectiveness, available to the public, promoting transparency and accountability in their programmatic efforts. Organizations that do not focus on evaluation efforts often cite the following reasons for bypassing this process: the expense, the time, the technical complexity, the lag behind behavioral and community change, and access to limited data (Levermore, 2008).

Beyond simply seeking to justify the existence and effectiveness of a single program, evaluation has the potential to serve a wider role within the global sport-fordevelopment community by:

1) adding knowledge of the precise circumstances under which positive outcomes occur,

2) providing recommendations about how to achieve these outcomes in varying contexts, and

3) providing methods for training local leadership of programs (Right to Play, 2008). 
Due the global interest in organizations willing to partner with development efforts, best practice organizations should be evaluated under one consistent evaluation protocol to glean a comparative analysis of football-for-development outcomes in different cultural contexts.

In seeking to develop this type of evaluation procedure, it appears most logical to create a measurement tool that specifically addresses the promoted strengths of sport-fordevelopment programs, and the areas that all programs should focus on to increase impact: cultural relevance, community ownership, and sustainability measures (Brunelli \& Parisi, 2011; Coalter \& Taylor, 2010; Levermore, 2008; Right to Play, 2008).

\section{The Community Organization Health Model}

Using health models to create evaluation. While it is feasible to create a rigorous evaluation that fits an individual program, it is often more difficult to create an evaluation that fits in a generalizable way across various programs and locations. This problem of generalizability is not a new one for the sector of health research. Public and community health researchers have sought to answer the problem of generalizability by using agreed upon health models and conceptual frameworks that fit multiple programs, to create standardized quantitative and qualitative evaluations (Glanz et al., 2008). Conceptual frameworks provide structural clarity and direction in evaluating both expected and actual outcomes of a program's efforts; however, for a health model's framework to be useful in creating evaluation tools, the program(s) in question should value and reflect the basic tenets of the model.

Given the complexity of HIV/AIDS and the varying cultures which it affects, the structural framework of a health model may be the best way to create a uniform 
evaluation procedure for football-for-development programs. Since HIV prevention and sport-for-development programs are best implemented through a grassroots, bottom-up approach, it seems to most appropriate to use a health model for evaluation that encompasses these traits as well. The Community Organization Health Model (COHM) is one such health model. The COHM emphasizes the ability to "start where the people are" in engaging community for health change (Minkler \& Wallerstein, 2002, p. 280). This model seeks to assist the community in identifying common problems, creating collective goals and mobilizing resources to address those problems (Minkler \& Wallerstein, 2002).

When examining the way in which the COHM works, it helps to understand how "community" is defined. While community can be defined in a variety of ways, depending upon the cultural context, the COHM refers to it as individuals fitting into one of the following categories:

1) categorical community - based upon geographical location, occupation, or gender,

2) ecological systems community - based upon population characteristics (size, technology exposure etc.), or

3) social systems community - based upon social, political or economic interactions (Minkler \& Wallerstein, 2002).

As with any theoretical model/framework, the COHM has multiple iterations; however, each variation shares the same basic six tenets, as reflect in Figure 1 below. Effective programs, seeking to reflect the COHM, address each of these tenets in both development and implementation efforts (Minkler \& Wallerstein, 2002). 


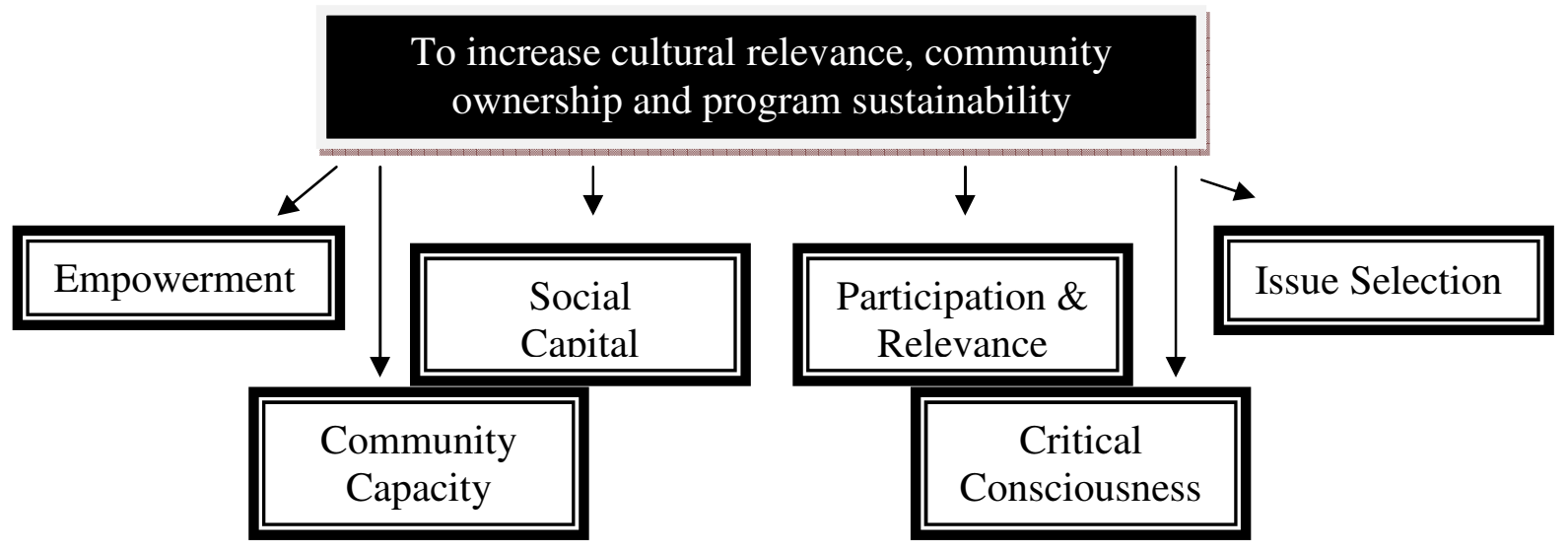

Figure 1. The Community Organization Health Model (COHM) Tenets.

COHM tenets. Minkler and Wallerstein (2002), define empowerment as the "social action process for people to gain mastery over their lives and the lives of their community" (p. 288). This tenet promotes community equity and pushed for community members to build competency within the political sector (Minkler \& Wallerstein, 2002). An empowered community, that lacks political competency, may be very good at expressing what they need without the ability to obtain the necessary resources for change. Empowerment can and should occur on three levels: individual, organizational and community (Minkler and Wallerstein, 2002).

Empowerment can occur as an end goal, as a process or as both a process and an end goal. The concept of empowerment is primarily psychological in nature and revolves around internal resources (Tengland, 2007). These internal resources include:

1) Knowledge - academic in nature,

2) Self-esteem - viewing self as a person of worth,

3) Self-efficacy - belief in self in regards to completing a specific task, and

4) Self-confidence - a general belief in self to solve problems successfully in life (Tengland, 2007). 
When empowerment is viewed as a process, it takes primarily an individual focus; however, the end result of empowering organizations and institutions can often only be achieved as a result of the process of empowering individuals in the community (Tengland, 2007). This process of empowering individuals creates opportunities to engage in the second tenet: a critical consciousness discussion of issues.

Critical consciousness refers to "consciousness based on reflection and action in making change" (Minkler \& Wallerstein, 2002, p. 288). Critical consciousness is the engagement of dialogue that stems from empowered individuals (Minkler \& Wallerstein, 2002). For this dialogue to occur individuals must be: 1) aware and educated about the issues under discussion, 2) willing to critically assess the roots and 3) motivated to identify solutions to the problem (Minkler \& Cox, 1980; Wallerstein \& Bernstein, 1988). As the strength of a community grows, there will be expanded forums for discussion about the cause of societal problems and the action the community should take in order to address these concerns. Critical consciousness discussion can assist a community in selecting a relevant issue and organizing the effort to address that issue.

Issue selection becomes pivotal in guiding the success of a community effort. This tenet refers to the ability to "identify winnable and specific targets of change that unify and build community strength" (Minkler \& Wallerstein, 2002, p. 288). These issues are primarily identified through the participation of the community, but a leader is often needed to focus attention on the few issues that are most feasible given the available resources and cultural restrictions. Leaders should articulate these issues to the community in such a way that community members can reiterate them simply to one another and understand the direction of effort (Minkler \& Wallerstein, 2002). In order 
for the community effort to move forward in unison there must be strong cohesion present with community members.

Social Capital refers to the "relationships between community members defined by trust, reciprocity and civic engagement" (Minkler \& Wallerstein, 2002, p. 288). To build social capital, members of the society must perceive that the relationships they form to be horizontal in nature, with all individual working toward the betterment of the community (Kreuger, Lezin \& Koplan, 1997; Minkler \& Wallerstein, 2002; Misener \& Mason, 2006). For this reason, communities with social capital are defined by frequent supportive interactions between community members and a general feeling of identification with the community as a whole (Campbell, 2001; Coalter, 2010a). This ensures that communities are better able to facilitate cooperation among community members for mutual benefit. The level of cooperation and civic participation garnered often reflect the relevance of programmatic efforts or community initiatives.

Relevant community programs start at the grassroots level and work to give community leaders the reigns in directing program direction and effect. To further enhance ownership, all members of the community should have equal access to the power and resources meant to benefit the community (Goodman et al., 1998; Minkler \& Wallerstein, 2002). A program that exhibits a strong connection to the culture and its people will often successfully involve community members in maintaining its efforts (Goodman et al., 1998; Minkler \& Wallerstein, 2002). However, even relevant efforts and ownership of a program can be derailed if the community does not accurately account for and plan for the development and maintenance of its resource capacity. 
Minkler \& Wallerstein (2002) describe community capacity as the "characteristics of community affecting its ability to identify, mobilize, and address problems" (Minkler \& Wallerstein, 2002, p. 288). A community's capacity depends upon: 1) skills and resources, 2) a critical reflection of needs, 3) a sense of community, 4) understanding of history and culture and 5) clear articulation of values. Each of the needs build on the others, and all five must be present for a community to be at its full capacity. Community capacity is dynamic in nature and develops in stages, including both an inventory of current skills and resources and developing a plan for cultivating new resources (Goodman et al., 1998). The greater the community capacity, the more likely the community members will feel satisfied with their contribution and satisfied with the program's continued presence.

Each of the six COHM tenets is fluidly connected to the others, addressing multiple dimensions in the process of organizing and creating sustained involvement in a community-oriented health initiative.

COHM and HIV prevention. Due to the COHM's focus on creating community change via community engagement, it appears to offer a natural fit to HIV prevention programs. However, the connection of the COHM to HIV prevention is more than anecdotal and logical in nature. Early in the 2000s, UNAIDS released a number of "Best Practice" papers relating to HIV prevention and treatment, encouraging programs to go beyond individual change to address social and economic contributors to the spread of the virus (UNAIDS, 2001; 2005). These "Best Practice" papers focused on engaging the communities in critical consciousness dialogue, ways to identify relevant issues and uniting the community in action (Campbell \& McPhail, 2002; UNAIDS, 2005). 
In addition to the best practice research by UNAIDS, a number of individual case studies have examined the effectiveness of empowerment, critical consciousness and relevance in HIV prevention programs in youth and women (Campbell \& McPhail, 2002; Campbell, Foulis, Maimane, \& Sibiya, 2005; Gregson, Terceira, Mushati, Nyamukapa \& Campbell, 2004; Piot, Bartos, Larson, Zewdie \& Mane, 2008). Campbell et al.'s research (2005) concluded that grassroots organizations, offering low cost community events, were able to successfully bring together youth from varying social classes to engage in an interactive discussion about HIV. Aside from simply bridging the social barrier gap, Campbell \& McPhail (2002) found the interactive discussion to show an improvement in the critical thinking capacity of the youth participants. Gregson et al., (2004) provided further confirmation that a critical consciousness discussion, resulting from repetitive contact of community groups, allowed for a clearer understanding of how HIV/AIDS impacted the community. Since no one individual's views develop in isolation from social networks and culture, programs should seek to use community connection as a way to enhance a community's capacity and assist in cultural change efforts (Campbell \& McPhail, 2002; Gregson et al., 2004; Coalter, 2009).

\section{Literature Review Summary}

HIV has established itself as a lasting and complex worldwide issue. However, researchers, international and NGO leaders are making progress through an intent focus on prevention efforts. Due to sport's unique attributes and ability to shape individual and cultural development, it is currently being utilized as a tool to address HIV prevention in African countries. Within the use of sport, however, exists a problem: the need for a more uniform evaluation to track and compare sport-for-development program efforts. 
Health models have often served as a solution to this same problem in other health initiatives, serving as the guiding framework for quantitative and qualitative evaluation development. For this reason and due to the unique complexity of HIV and sport-fordevelopment as a tool, the COHM appears to be a potential fit for developing an evaluation protocol. It reflects HIV best practices in engaging community, and it encompasses the positive individual and community development focus of sport; as such, the COHM needs to be explored further to clarify the potential of its use to develop an evaluation assessment for football-for-development programs addressing HIV. 


\section{Chapter 3}

\section{Methods}

Given the strong support of the sport-for-development movement and its apparent fit within addressing HIV in youth, this analysis functioned under the assumption that sport-for-development is an effective and valuable tool for addressing HIV prevention. Within the use of sport-for-development programs comes the problem under investigation: the need to establish a uniform protocol from which to evaluate HIV sportfor-development program effectiveness, in regards to: 1) cultural relevance of the program, 2) community ownership and 3) sustainability through partnership resources (Brunelli \& Parisi, 2011; Coalter \& Taylor, 2010c; Levermore, 2008; Right to Play, 2008).

Given this problem, the purpose of this study is to examine whether the Community Organization Health Model (COHM) would be a feasible model from which to design such an evaluation. I evaluated the promotional and evaluation materials (video transcripts, website promotional materials and outside evaluations) of three best practice, HIV sport-for-development programs to examine the extent to which the organizations mirrored the basic concepts of the COHM. The extent to which they embodied, or failed to embody, the COHM tenets determined the applicability of the model in creating a set of evaluation procedures for HIV sport-for-development programs. Furthermore, I evaluated the best practice data for emerging patterns and theories that were better suited to evaluating relevance, ownership and sustainability. 
As such, I decided an emergent, qualitative design approach best fit the study problem. Due to both the complexity of the problem, and the exploratory nature of this analysis, I believed that a qualitative approach allowed for a more thorough examination of the research questions and fit of the health model to the data. The type of material used, promotional documents and evaluations, also justified a qualitative approach. This material should inherently reflect each organization's dispositions and values; however, discerning and interpreting values of organizations, without confirming with stakeholders, is both an objective and subjective process. Qualitative approaches allow for subjectivity as new relevant data emerges from the analysis; therefore, I also utilized an emergent design to allow the leniency of adjusting the study's research questions if new themes and outcomes emerged from the data, even if they were not in alignment with the research questions (Mayring, 2000; Miles \& Huberman, 1984; Saldana, 2009).

The inherent social and cultural complexity of both the HIV virus and the proposed benefits of sport-for-development programs make a structuralism framework, most appropriate for this analysis. Structuralism draws attention to the social and physical institutions that help create meaning within a culture (Denzin \& Lincoln, 2000; Patton, 2002). Within this framework, I approached the study with an interpretivist paradigm, which aimed not to verify whether the COHM was a truth (e.g., a correct or incorrect hypothesis) but rather looked for emerging patterns that either confirmed the feasibility of using the COHM or offered recommendations of other best fit theories or models (Denzin \& Lincoln, 2000; Patton, 2002). This paradigm assumes that the quantitative facts and qualitative values, within an organization's promotional materials, cannot be cleanly separated. As such, I brought my own interpretations to the 
promotional content. In order to counteract my subjectivity, I noted areas of potential bias in my interpretation throughout the process of both creating and editing the codebook, as well as in the actual process of coding the material.

\section{Study Location}

While the organizations examined in this analysis all implement their programs in Sub-Saharan Africa, this analysis took place in San Luis Obispo, California.

\section{Study Design}

Methods for examining documents: Content analysis. Due to the focus on evaluating written promotional documents, content analysis was chosen as the most appropriate methodology for this analysis. Patton (2002) describes content analysis as "any data reduction effort that attempts to make sense of a volume of written material, attempting to identify core consistencies and meanings (p. 453). Content analysis, as it relates to an academic discipline, is differentiated into two separate methods: quantitative and qualitative (Krippendorff, 1980). Traditional quantitative analysis attempts to "quantify and analyze the presence, meaning and relationships of words and concepts" by examining 1) the frequency and 2) the length of time spent upon certain topics or themes in a body of literature (Krippendorff, 1980, p. 54). This analysis is presumed to allow the researcher to make inferences, based on numerical significance, about the intention and behavior of the individual and/or organization that produced the document. Quantitatively, content analysis is often used to verify or confirm hypothesized relationships rather than to discover new and emergent patterns (Riffe, Lacy \& Fico, 1998). 
During the 1950s, researchers began to realize there was further benefit in evaluating the relational component of textual content. This placed the focus not only on the frequency of a word but also the context in which the word appeared and its relational meaning to the rest of the document (Mayring, 2000). In order to explore this relational analysis, researchers developed a qualitative version of content analysis. Qualitatively, content analysis is still approached with a set of empirical coding categories, but it allows for the discovery of new and emerging patterns from the text (Altheide, 1996; Mayring, 2000). In this way, the documents are left open to significance that may not have been hypothesized prior to the beginning of the evaluation (Altheide, 1996; Reis \& Judd, 2000).

Qualitative content analysis was chosen as the appropriate method of analysis for this study for two primary reasons: 1) due to the amount of contact with the programs in question and 2) to allow for a more exploratory analysis of the documents in question. First, due to time and location restrains, I was neither able to observe programs directly nor speak with program representatives. For this reason, there was a need for an empirical method of analysis using material that could easily be accessed from a distance. Second, qualitative content analysis, compared to quantitative, allowed for a more open investigation of the presence, or lack thereof, of the health model in each organization's promotional material. The aim of this analysis was not only to test for the presence of COHM tenets, but to see the extent to which this model's tenets appeared in material. None of the organizations openly stated that they used this model in their organizational or program implementation; so, the qualitative approach allowed for the possibility of more relevant themes or models to appear through examination of the data. 
To increase the rigor of the analysis, as well as ensure some measure of reproducibility, the codebook used for sorting and analyzing data was validated using quantitative measures, with the process appearing in Appendix A (Neuendorf, 2002). This ensured the codebook was empirically sound, regarding the validity and reliability of its measures, allowing the potential for others to code the promotional material in a similar way. The empirical basis for coding allowed for a more accurate and trustworthy interpretation of the data, as it sought to reduce bias and inaccuracies in the procedure.

Programs and criteria for inclusion. The criteria for inclusion were based upon previous research into the best practices and methods of HIV prevention, as well as rational limitations for the scope of the study. Purposeful, criterion sampling was engaged in for the purposes of this study. This type of sampling narrowed the scope to best practice organizations that offered the greatest chance of reflecting successful and established program practices in the football-for-HIV development arena. An exhaustive search of organizations using football to address HIV development in Africa, via health and medical databases (Sport Discus, PubMed etc.), the streetfootballworld network and the United Nation's sport-for-development database, produced 16 organizations. Of those organizations, the list was narrowed to three meeting the following criteria:

1) Organizations must be employing the use of soccer/football as the primary means of interacting with youth in the program. This criterion was included due to soccer's high popularity and visibility worldwide (Mwaanga, 2010).

2) The organizations' primary focus must be to address the issue of HIV prevention in youth. Within this criterion, it was possible and acceptable for the organization to be working to provide youth with other opportunities as well; however, they 
must dedicate a substantial part of their programs to focusing on HIV prevention in youth (Lindsey \& Banda, 2010; UNAIDS, 2010; World Health Organization, 2011b).

3) The target population of their efforts must include females. This criterion was established, due to the exponentially higher rate with which young women are infected with HIV, compared to men, and due to the fact that they are less likely to engage in sport or be given the opportunity to participate (Human Rights Watch, 2005; UNAIDS, 2010). For this reason, only programs targeting female involvement (whether single gender or combined gender) were included.

4) Organizations must be involved with the streetfootballworld/FIFA network. This criterion was included due to FIFA's work in expanding partnership opportunities between international organizations and local HIV prevention programs that use football as the primary means of engaging youth. In addition, streetfootballworld's partnership ties may further enhance individual organizations' abilities to provide for their local program. FIFA and streetfootballworld collectively offer the opportunity for expanded resourcessuch as FIFA's Football for Hope Centers. Membership also recognizes that the organization recognizes the importance of these partnerships.

5) Each organization must have published research that is directly tied to their promotional material online. In order to establish itself, grow and become sustainable, an organization must produce ongoing evaluation of its efforts. A research and development section shows that the organization recognizes the importance of evaluation efforts, as well the need to make themselves accountable 
to the effect the organization plays on the community (Coalter \& Taylor, 2010; Levermore, 2011; Right to Play, 2008).

6) Finally, organizations must have been in existence for at least five years prior to the initiation of this study. This criterion was put in place to eliminate programs that have not yet established community presence and ownership.

It is important to note that I left certain areas of uniformity intentionally uncontrolled. The goal of this research was to examine the potential the COHM offered for building a uniform evaluation tool for football-for-development programs. One of the problems cited with establishing a quality evaluation protocol is the issue of generalizability; therefore, there is a need to establish a protocol that can fit multiple cultural contexts effectively. From my literature review study of the problem, I determined the above criteria: 1) to be appropriate in narrowing the scope of the analysis in the ways recommended by HIV researchers, and 2) to encompass organizations that have already established some measure of relevance, ownership and sustainability.

Organizations meeting inclusion criteria. After I compared all 16 relevant organizations to the inclusionary criteria, I chose the three organizations reflected in Table 1, Grassroot Soccer, Mathare Youth Sports Association and WhizzKids United, for evaluation within the scopes of this study. 
Table 1: Football-for-Development Organizations Meeting Inclusionary Criteria

\begin{tabular}{|c|c|c|c|}
\hline \multirow[t]{2}{*}{ Criteria } & \multicolumn{3}{|c|}{ Organizations } \\
\hline & $\begin{array}{c}\text { Grassroot Soccer } \\
\text { (GRS) }\end{array}$ & $\begin{array}{c}\text { Mathare Youth Sports } \\
\text { Association (MYSA) }\end{array}$ & $\begin{array}{c}\text { WhizzKids United } \\
(W K U)\end{array}$ \\
\hline Primary Sport & Football & Football & Football \\
\hline Developmental Focus & HIV Prevention & $\begin{array}{l}\text { HIV Prevention \& } \\
\text { Education }\end{array}$ & $\begin{array}{l}\text { HIV Prevention \& } \\
\text { Education }\end{array}$ \\
\hline Gender Focus & Both & Both & Both \\
\hline $\begin{array}{l}\text { Involved with } \\
\text { FIFA/SFW? }\end{array}$ & $\begin{array}{l}\text { Yes, Football for } \\
\text { Hope Center Host }\end{array}$ & $\begin{array}{l}\text { Yes, Football for } \\
\text { Hope Center Host }\end{array}$ & $\begin{array}{l}\text { Yes, Football for } \\
\text { Hope Center Host }\end{array}$ \\
\hline Published Evaluations & Yes & Yes & Yes \\
\hline Founding Year & 2005 & 1987 & 2004 \\
\hline
\end{tabular}

\section{Data Collection}

Data were gathered from the three organization websites to undergo content analysis. The documents that qualified for content analysis had to fall into one of the following categories:

1) pamphlets, promotional items or "toolboxes," produced by the organization, for public or programmatic use,

2) research evaluations appearing on the promotional websites. This specification was set up to filter the number of evaluative pieces that qualified for the analysis. I made the assumption that this would highlight the evaluations each organization felt most relevant to its work.

3) all organizational background, mission and philosophy statements,

4) transcribed promotional video content and blog content directly linked to from the promotional website. Not all video material was located directly on each organization's website; however, each organization promoted their own YouTube channel on its website. Video transcripts were created from both the referenced YouTube channels as well as the direct website videos. 
5) each organization's self-developed evaluations, year-end reports and strategic plans

I included all items that were visible or linked to the organization's website. I examined the documents, via content analysis, for connection to the concepts and themes of COHM. I remained open to all emergent patterns that indicated other, more relevant, health theories. Documents were analyzed until a thorough level of saturation was reached. After establishing the coding procedure, the coding and analysis of the material occurred simultaneously allowing for a proper evaluation of the points of saturation for each organization. Once saturation appeared to have been achieved, an additional three documents, per organization, were analyzed to ensure no new concepts or themes presented themselves (Neuendorf, 2002; Patton, 2002).

\section{Design of the Instrument}

Within qualitative content analysis, a study's research questions guide the creation of coding units for analysis (Neuendorf, 2002). The following research questions (RQs) were explored in this analysis, all relating directly back to the three recommended areas of evaluation: cultural relevance, community ownership and sustainability through partnerships.

1) To what extent do the three organizations in question convey, or fail to convey, the tenets of the COHM in their comprehensive promotional material?

2) To what extent are the organizations establishing community ownership?

3) To what extent are the organizations establishing cultural relevance?

4) To what extent are the organizations establishing sustainability? 
These research questions served as a guide for the coding categories in the initial pilot codebook. Since the three recommended aspects of evaluation- ownership, relevance and sustainability- were intertwined within various aspects of the COHM's tenets, these three items did not have their own separate coding categories during the analysis. I made this decision to establish a more empirical and reproducible codebook by reducing the overlap between coding categories. I revisited these three themes, at the end of the coding process, by performing a word count on key words relating to these three topics, to determine the frequency and contexts in which these concepts were emphasized. This key word search helped to reveal the relevant coding categories that encompassed each recommended evaluation area and highlighted the context in which they appeared.

From the research questions, each of the six tenets of the COHM was established as a main category code: "empowerment", "critical consciousness", "issue selection", "community capacity", "social capital" and "participation \& relevance". Aside from the purpose of examining the presence of the COHM, I chose the as main categories for coding based upon the recommendation from Neuendorf (2002) that past research theories can be a valuable technique for selecting coding variables, as it helps ensure the face validity of concepts and the clarity of codebook categories.

I developed the remainder of the codebook through an a priori examination of roughly $30 \%$ of the coding material (Weber, 1990). The a priori examination identified relevant sub-categories for each COHM tenet, in addition to any other relevant themes that merited an appearance in the codebook. The analysis reflected two additional main 
categories, "sport-for-development" and "partnership \& sustainability" that showed a strong presence in the promotional material.

I chose "sport-for-development" as a relevant coding category, as each organization referenced the proposed benefits of sport as one of the theoretical backings for program design. This coding category's primary use in the final evaluation was to justify that each chosen organization did, in fact, fit the criteria of inclusion for the study; namely, that they are using football for HIV prevention, catering to youth and working toward the inclusion of both genders. It also provided a summary of the specific focus of each organization's efforts, which added context to the presence of certain COHM tenets.

I chose "partnerships" as a relevant coding category, as both an initial reading of the organizational documents and research pertaining to the problem emphasized the need for varying types of partnership and a coordinated effort to create effective sportfor-development programs. This code also justified that each chosen organization did, in fact, fit the criteria of inclusion for the study; namely, that the organizations reflected a connection to FIFA and streetfootballworld. Finally, this code merited addition, as the COHM does not encompass one specific tenet focusing on partnerships for sustainability; this concept was spread throughout multiple tenet categories.

In addition to adding two main categories, the a priori analysis assisted in identifying the relevant subcategories for each main category. It should be noted that certain biases were created in the editing of the COHM tenets in the codebook. Due to the breadth of the COHM, each tenet had a broad definition and the tenet content often overlapped. To reduce the number of units in the coding process that were double coded, the tenets were given more strict definitions and parameters. This affected the way that 
both the secondary coder and I performed coding; however, I saw it as a relevant bias to create in order to add rigor to the codebook. A copy of this pilot codebook can be found in Appendix B. Table 2 below reflects the main categories and subcategories created, from the a priori analysis.

Table 2: Pilot Subcategories Created From A Priori Evaluation of Data

\begin{tabular}{|c|c|c|c|c|}
\hline \multirow{2}{*}{$\begin{array}{l}\text { Main Category } \\
\text { Sport-for- } \\
\text { development }\end{array}$} & \multicolumn{4}{|c|}{ Subcategories } \\
\hline & $\begin{array}{l}\text { Unifying the } \\
\text { Community }\end{array}$ & Youth & Gender Equality & \\
\hline Empowerment & $\begin{array}{l}\text { Competence \& } \\
\text { Self Efficacy }\end{array}$ & $\begin{array}{l}\text { Knowledge \& } \\
\text { Achievement }\end{array}$ & $\begin{array}{l}\text { Mastery of Self \& } \\
\text { Responsibility }\end{array}$ & $\begin{array}{l}\text { Hope \& } \\
\text { Optimism }\end{array}$ \\
\hline $\begin{array}{c}\text { Critical } \\
\text { Consciousness }\end{array}$ & Awareness & $\begin{array}{c}\text { Political \& } \\
\text { Social Reality }\end{array}$ & $\begin{array}{l}\text { Identifying } \\
\text { Practical } \\
\text { Solutions }\end{array}$ & \\
\hline Issue Selection & $\begin{array}{l}\text { Process of } \\
\text { Selecting }\end{array}$ & Research Issues & $\begin{array}{l}\text { Community } \\
\text { Choice Issues }\end{array}$ & Strategic Goals \\
\hline $\begin{array}{c}\text { Community } \\
\text { Capacity } \\
\end{array}$ & Access & Mobilization & Shared Expertise & $\begin{array}{l}\text { Collective Skills } \\
\text { \& Education }\end{array}$ \\
\hline Social Capital & $\begin{array}{c}\text { Trust \& } \\
\text { Reciprocal } \\
\text { Relationships }\end{array}$ & $\begin{array}{c}\text { Civic } \\
\text { Engagement }\end{array}$ & $\begin{array}{l}\text { Helping Self \& } \\
\text { Community }\end{array}$ & \\
\hline $\begin{array}{l}\text { Participation \& } \\
\text { Relevance }\end{array}$ & $\begin{array}{l}\text { Starting "Where } \\
\text { the People Are" }\end{array}$ & $\begin{array}{l}\text { Evaluation \& } \\
\text { Progress }\end{array}$ & $\begin{array}{c}\text { Culturally } \\
\text { Appropriate } \\
\text { Implementation }\end{array}$ & $\begin{array}{l}\text { Owned/Managed } \\
\text { by Community }\end{array}$ \\
\hline $\begin{array}{l}\text { Partnerships \& } \\
\text { Sustainability }\end{array}$ & $\begin{array}{c}\text { Awareness \& } \\
\text { Advocacy }\end{array}$ & $\begin{array}{l}\text { Resources: } \\
\text { Knowledge, } \\
\text { Material \& }\end{array}$ & $\begin{array}{l}\text { Plans for Growth } \\
\& \text { Sustainability }\end{array}$ & $\begin{array}{l}\text { Role of FIFA } \\
\text { and SFW }\end{array}$ \\
\hline
\end{tabular}

Due to the extent of the coding themes in this initial pilot codebook, I did not create an "other" coding category; however, I did create a "no-code" category. There were a variety of sections in the research evaluation studies that encompassed background information that was related to the issue under concern (HIV in youth) but did not directly make reference to the actions of any of the programs under study. Since this background information was not relevant to the purpose of this analysis, I created the 
coding category of "no-code." The "no-code" theme also ensured that no relevant themes were missed or uncovered during examination of the entirety of the data.

Prior to the pilot test, the unit size was developed. I noted during the a priori examination of relevant themes that the promotional material often created breaks in ideas/themes within a paragraph of roughly three sentences. For this reason, I defined a "coding unit" as three sentences OR the break in a paragraph, whichever came first in the material. I included an explanation of unit size in the instructions for coding, which are located in Appendix C.

Establishing reliability of codebook. Within quantitative content analysis, reliability is easily established by the rigorous and unchanging coding categories (Riffe et al., 1998). Due to the qualitative nature of this content analysis, I established reliability by creating stability within the coding system through intra- and inter-coder reliability. While these methods of reliability are primarily quantitative in nature, they assisted in establishing an empirical codebook and coding protocol. This increased rigor in the codebook was meant to strengthen the conclusions of the qualitative evaluation by ensuring a measure of reproducibility.

Intra-coder reliability was performed twice during this study, once with the pilot codebook to determine clarity of the codebook and my biases and tendencies while coding, and a second time to determine the consistency with which I was coding data with the final codebook. For both intra-coder reliability tests, I coded roughly $10 \%$ ( $\mathrm{n}=$ 261 coded units) of the material and one week later coded the same material a second time. The material coded during each of these trials was chosen randomly and equally 
from each organization's documents. The pilot test material represented equal length documents from each organization.

Inter-coder reliability was established using an outside coder, a graduate level engineering student, who served as a second coder to the primary researcher for both a pilot test- refining the coding procedure- and in coding an example of each different type of document with the final codebook. The pilot test on the codebook featured approximately $10 \%$ ( $\mathrm{n}=261$ coded units) of the total documents to be coded. The material coded during each of these trials was chosen randomly and equally from each organization's documents. The pilot test material represented equal length documents from each organization. To reduce the artificial inflation of the reliability factor, resulting from individuals who work closely together, the outside coder was not included in the initial determination of coding categories, and he did not have access to the full purpose of the study. He served primarily to code pilot data, assist with the alteration of the coding protocol and to provide feedback about clarity of the protocol (Weber, 1990). The secondary coder ensured the codebook was empirical enough to create reproducible results from different coders.

I chose Cohen's Kappa coefficient for both intra- and inter-reliability calculations, as this statistic takes into account random chance agreement; however, due to the extent of the codebook (34 codes), I did not speculate that the random chance of selecting the exact sub code would be high between the two researchers. Given that Cohen's Kappa agreement is seen as a relative conservative measure, I predicted that the agreement level with this reliability factor may be lower than the agreement actually present (Mayring, 2000; Weber, 1990). 
After the first pilot test, the Cohen's Kappa was calculated and expected to be a value of at least 0.70 , a well above a chance agreement, if the codebook was to remain unedited. Regardless of the percent agreement results, I expected edits to the codebook would be inevitable. For this reason, the final codebook was also put through inter-coder reliability measurements with a sample of approximately $5 \%(\mathrm{~N}=130$ units of code $)$ of the total coding material to ensure improvements in clarity were made after the pilot test. Cohen's Kappa was, again, calculated for the final codebook.

The aim for all reliability indices was an agreement value of at least 0.70 , signaling a well above chance agreement between coders (Lombard, Synder-Duch \& Bracken, 2004). I aimed for 0.70 as the target goal; however, given the length and extent of the codebook and the overly conservation nature of the Cohen's Kappa, I deemed a value within the range of $0.60-0.70$ acceptable, as it still fell within the magnitude recommendations (Lombard et al., 2004).

Pilot testing results. In performing the reliability tests for inter-coder agreement, the secondary researcher used a set of instructions (Appendix C) with the pilot codebook. The primary and secondary researcher coded the same $10 \%(n=261$ coded units $)$ of documents independently. Two Cohen's Kappa calculations were calculated for the pilot data; one reflected the reliability factor if the researchers exactly matched subcategories, and one if the researchers matched main categories, but differed in the subcategories. Kappas were calculated for both due to the need to differentiate between clarity issues within main category definitions versus subcategory definitions. Cohen's Kappa for subcategory agreement was calculated to be 0.44 , and the main category agreement was calculated to be 0.63 . These results reflected large discrepancies within the definitions of 
various subcategories in the codebook and reflected overlap of a few main category themes.

While the main category agreement fell within an acceptable range, the subcategory agreement was well below the desired level. Even though the subcategory agreement was low, I concluded that the subcategories should not be rejected, but rather refined and made more specific, as each subcategory appeared numerous times in coding (Holsti, 1969; Patton, 2002).

Given the large difference between the agreement in main category and subcategory, I re-examined the codes that were main category, but not subcategory, matches. The two main categories that reflected the most confusion were "empowerment" and "participation \& relevance." Due the broad meaning of the concept of empowerment in Minkler and Wallerstein's (2002) COHM literature, I adjusted the codebook definitions so that the four subcategories became even more distinct- serving as building blocks for one another in the process of empowerment. In addition, I edited the "empowerment" code to primarily reflect a focus on the individual, over the organization or community.

The second main category with discrepancies was the "participation and relevance" category. The "participation and relevance" code included topics that cross over multiple coding categories. For this reason, I removed one subcategory from the "participation and relevance" category, and re-focused the definitions on emphasizing an actual evaluation of effectiveness to determine program relevance, rather than philosophical statements about the intention or hope for program relevance. 
To further clarify issues, I discussed the troublesome areas with the secondary researcher, after calculating the agreement level. I asked the secondary researcher to comment about his understanding of the coding procedure and his thought process when coding. The secondary researcher stated that he primarily focused on the key words and bolded concepts for each category, rather than reading the unit under analysis for meaning before deciding on a code. This brought into light one of my biases as the primary researcher; I coded by way of examining the passage's meaning, over than focusing on the key word emphasis in the codebook. My saturation with the study material made me more apt to look for the meaning of the passage rather than coding based completely off of the definition provided. For this reason, the aim of pilot codebook edits were focused on re-examining the clarity of key words in relation to encompassing the meaning of each main category.

Given the trouble in coding via the key word definition, I used the MAXQDA 11 system to run a key word search, bringing up all document content that reflected the key words for each category. I read each passage to determine whether the key word accurately connected the passage to the appropriate code category. If it did not relate the passage to the coding category, the key word was removed from the word bank on the codebook.

Final codebook reliability results. After I finalized the codebook, the secondary researcher and I performed another inter-coder reliability test. For this second test, we followed the same independent coding process; however, for this test, only $5 \% \quad(n=131$ coded units) of the overall study material was coded, due to time constraints. I deemed this amount appropriate for the test, due to the number of coded units it produced for 
comparison. For the second reliability test, the Cohen's Kappa coefficient reflected an agreement of 0.60 for main category agreement. While it appears that the agreement decreased slightly, the second reliability test produced a 0.57 agreement within subcategories, showing that nearly all of the disagreement between subcategories was corrected through the alteration of the codebook. The slight drop of main category agreement was accounted for by the reduced amount of coded units, as compared to the pilot test. Cohen's Kappa coefficient is known to increase with a greater number of codes and decrease with fewer codes (Lombard et al., 2004). Due to this limitation, I took the large improvement in subcategory coding agreement and the relatively stable agreement of the main category to be acceptable values for the second set of coding. Due to this agreement level, I proceeded in coding all documents with the second version of the codebook (Appendix D).

In addition to the reliability measures, the final codebook content was also confirmed to be appropriate in reflecting the meaning of the main category concepts by the committee of experts serving in a consultation role for this study. While the parameters that limited the definition of some codes may have caused a bias, the codebook definitions were not incongruent with the meaning of each tenet in the COHM. While using this codebook for all of the study's documents, a few additional areas of bias were discovered, which are mentioned in relation to the coding results.

Validity and triangulation. I established validity/credibility via triangulation measures as well as expert consultant commentary on the clarity and accuracy of the codebook in reflecting the COHM tenets. Guion, Diehl, and McDonald (2011, p. 2) define triangulation as a method of evaluating a research study from multiple 
perspectives to ensure the findings "accurately reflect the situation... and are supported by evidence." Data triangulation and investigator triangulation were the primary methods used in this analysis.

The goal of these triangulation measures was to ensure the fit of the data to the concepts created as coding categories (Dey, 1993; Patton, 2002). Triangulation and examination by health education experts helped to ensure the codebook accurately represented concepts and was capable of producing the data to answer the posed research questions (Holsti, 1969; Patton, 2002). The refinement of coding categories featured investigator triangulation through involving my efforts, a committee of expert consultants, and an outside coder unfamiliar with the analysis methods and purpose (Neuendorf, 2002). This investigator triangulation allowed for an accurate codebook, capable of reproducing coding results.

Triangulation also occurred through data sources: visual promotional materials, promotional materials in written form and evaluation materials from outside organizations. Each of these data sources featured: 1) different stakeholders within the NGO's efforts- participants, outside researchers, and NGO leaders, and 2) materials with differing styles of presentation.

Final coding procedures. I performed the finalized coding via the MAXQDA 11 computer program, to enhance the ability to quickly and easily manipulate data for analysis. I kept analytic memos during the process of coding to note troublesome areas of coding, areas of potential bias, and to note any significant changes that occurred in the coding process. 


\section{Chapter 4}

\section{Results}

This chapter presents the findings of the content analysis performed to examine the extent to which three best practice football-for-development organizations reflected the Community Organization Health Model (COHM). In total, the data analysis included 584 pages of documents, resulting in 2614 coded units of three sentences each. I used this amount of content in order to achieve proper saturation of the data. These data included at least one of each of the following documents from each organization:

1) Most recent strategic plan available (internal document)

2) One internal evaluation (internal document)

3) One external evaluation (external document)

4) One research article/thesis study (external document)

5) Full entirety of promotional material from each organization's website (marketing/advocacy material) and

6) Full transcripts of all videos linked directly with the website's promotional material (including the full transcripts of all videos found on each organization's YouTube Channel, which was linked to from the promotional website (marketing/advocacy material).

\section{Description of Organizations}

In evaluating the coding data from each organization, it is valuable to understand their similarities and differences. The following biographical descriptions provide background information on the cultural context and aim of each best practice football-for- 
development organization. This background helps to illuminate the extent to which each organization reflected the specific COHM tenets.

\section{Grassroot Soccer (GRS).}

Location: Zambia, Zimbabwe and South Africa (Flagship Programs)

Leadership Structure: Administrative leadership, largely non-local. Program

(implementing) leaders are local soccer players/former GRS participants.

Mission Statement: "Grassroot Soccer uses the power of soccer to educate, inspire and mobilize communities to stop the spread of HIV" (Grassroot Soccer, 2011b).

Strategy: "To achieve our mission, we continuously improve our innovative HIV prevention and life skills curriculum, share our program and concept effectively, and utilize the popularity of soccer to increase our impact" (Grassroot Soccer, 2011b).

Structure of Implementation for Programs: Eight, 45-minute sessions using an activitiesbased approach to educate about HIV prevention and life skills. These sessions train local role models through a five day course. In-school and after-school curriculum delivery, Skillz Street- a girl targeted intervention, Skillz tournaments- offering voluntary counseling and testing (VCT) and Skillz Holiday- week long camps with soccer tournaments during school holidays.

Emphasis: Educating youth about HIV. There are roughly 500,000 program graduates to date.

Partnership Connections: GRS rises above both the Mathare Youth Sports Association (MYSA) and WhizzKids United (WKU) in regards to pursuing and partnering with a variety of organizations to expand their resources. GRS has partnered with FIFA and streetfootballworld (SFW) to run one of the twenty Football for Hope centers in 
Africa, and it is part of both organizations' professional networks (Grassroot Soccer, 2011b).

\section{Mathare Youth Sports Association (MYSA).}

Location: Mathare Slums, Nairobi Kenya- one of the largest slums in Africa.

Leadership Structure: MYSA employs some non-local leaders; however, these individuals do not make decisions about implementation and program direction. Local committees of youth members make decisions about each MYSA zone's activities, and the youth themselves help coach, volunteer and maintain upkeep on each MYSA zone's programs.

Strategic Goals/Mission Statement: "Giving youth a sporting chance on and off the field" (Mathare Youth Sports Association, 2011).

Structure of Implementation for Programs: Uses the Kicking AIDS Out approach to educate kids about HIV through football. Any group of Mathare youth can create a team and participate for free. Teams earn points that help them in league standings by: 1) winning soccer tournaments, 2) engaging in community service work, 3) volunteering as a referee/coach or 4) participating in other MYSA educational programs. Leadership points are given for these activities as well, which make Mathare youth eligible for academic scholarships. Involvement is continuous.

Emphasis: Primary emphasis is educating youth through football, including HIV prevention, but also includes environmental clean-up, performing arts and photography activities. There are roughly 25,000 current, active members.

Partnership Connections: MYSA, due to its prolonged presence, has formed a positive relationship with the local government; however, due to the program's highly 
community oriented structure, it has not put a strong focus, until recently, on branching out to expand partnerships. The organization created a strategic focus on expanding partnerships, so it can continue to grow and sustain the leadership scholarships it offers participants. MYSA's partnership with FIFA and streetfootballworld, to run one of the twenty Football for Hope centers in Africa, is a solid beginning to creating further partnerships (Mathare Youth Sports Association, 2011).

\section{WhizzKids United (WKU).}

Location: Durban, South Africa.

Leadership Structure: The majority of the leadership for WKU is still non-local. The administrative staff team is made up of roughly half local leaders and half non-locals. WKU attempts to find and keep local volunteers active in the implementation of their programs.

Strategic Goals/Mission Statement: “To deliver effective HIV prevention, care, treatment and support to youth worldwide through the medium of football" (WhizzKids United, 2011).

Structure of Implementation for Programs: Four primary programs: 1) Health Academy, 2) life skills education, 3) mixed gender leagues and 4) peer education. The Health Academy features a football pitch that allows WKU to host large tournaments in conjunction with opportunities for VCT at the Academy. It also provides an area for the Life Skills Education program to take place. The mixed gender leagues and peer education programs take place directly within the schools in the area. 
Emphasis: Educating youth on HIV prevention and providing access to HIV care. Roughly 20,000 youth have been reached through Life Skills Program or Health Academy testing.

Partnership Connections: WhizzKids United has branched out to multiple areas to create partnerships that have added to the sustainability of the organization; however, it does not have the marketing and partnership presence that GRS exhibits or the long standing connection to community partners that MYSA exhibits. FIFA and streetfootballworld have recognized the value of WKU's efforts, and they have partnered with WKU to run one of the twenty Football for Hope centers in Africa (WhizzKids United, 2011).

\section{Data Analysis}

After I coded all documents, the total number of codes for each sub-category and main category were tallied, and I re-examined the "no-code" category to ensure that no new themes appeared during the full analysis. The re-examination of the "no-code" category confirmed that neither the preliminary examination of documents (to form the codebook), nor the actual coding of all study documents revealed new emerging themes from the data; however, two of the three programs did discuss their theoretical basis for program design and implementation. Both Grassroot Soccer and WhizzKids United voiced a theoretical backing in Bandura's Social Cognitive Theory (SCT) (Azzopardi, 2010; Farrar \& McGilvray, 2009; Grassroot Soccer, 2006; Grassroot Soccer, 2011). It is important to note that elements of the SCT overlap with tenets in the COHM, meaning that both theories could be used synonymously to describe program efforts and effectiveness. 
Since I found no emergent themes in the content analysis, the following results sections summarize the extent to which each organization, and all of the material as a whole, reflected the COHM tenets and the remaining additional codes. These data are reflected in multiple diagrams and tables. These diagrams reflect very simple descriptive statistics, as the evaluation was not meant to focus on a quantitative analysis. The quantitative presence of the codes is presented in the diagrams simply to provide a visual picture to complement the qualitative participant and organizational quotations.

\section{Research Question \#1: Presence of COHM Tenets}

Research Question (RQ) \#1: To what extent do the three organizations in question convey, or fail to convey, the tenets of the COHM in their promotional material?

After I completed coding of the data, I sorted it MAXQDA 11 and created simple comparisons and descriptive statistics. I created one main category summarizing the presence of all subcategories for each of the COHM tenets. After collapsing these data, the COHM tenets reflected roughly $47 \%$ of the content in all of the documents under analysis. I further broke down the overall presence of the COHM tenets across organizations and across the type of document. Table 3 reflects these data.

Table 3: Presence of the Community Organization Health Model (COHM) Tenets Across Type of Document and Organization

\begin{tabular}{|ccccc|}
\hline & $\begin{array}{c}\text { \% Presence of } \\
\text { COHM Tenets }\end{array}$ & $\begin{array}{c}\text { \% Presence in } \\
\text { Promotional }\end{array}$ & $\begin{array}{c}\text { \% Presence in } \\
\text { Internal Docs }\end{array}$ & $\begin{array}{c}\text { \% Presence in } \\
\text { External Docs }\end{array}$ \\
\hline Grassroot Soccer & $49 \%$ & $51 \%$ & $48 \%$ & $49 \%$ \\
\hline $\begin{array}{c}\text { Mathare Youth } \\
\text { Sports Association }\end{array}$ & $51 \%$ & $54 \%$ & $55 \%$ & $66 \%$ \\
\hline WhizzKids United & $33 \%$ & $59 \%$ & & \\
\hline All Documents & $47 \%$ & $53 \%$ & $45 \%$ & $25 \%$ \\
\hline
\end{tabular}

Note: Promotional documents included: all website material, video transcripts and toolboxes. Internal documents included: internal evaluations and strategic plans. 
External documents included: external reviews and evaluations published and nonpublished.

While the overall presence of the COHM tenets appears relatively low, it is important to put this percentage in the context of the number of coded units it represents. The $47 \%$ presence of the COHM signified approximately 1228 coded units in all of the data, showing a steady presence of the model's themes. In addition, the type of document reflected varying amounts of the model's codes. Many of the outside evaluations contained literature review material that did not directly pertain to the efforts of the organizations in question. For this reason, a large amount of material remained uncoded. I chose to keep this non-coded material in the final calculations of frequency and presence due to the high presence of COHM tenets themes throughout the relevant portions of these evaluations. Table 4 reflects the portions of the documents coded under each coding category.

Table 4: Percent of Documents Coded in Each Main Category

\begin{tabular}{|c|c|}
\hline & \% of Total Units Coded \\
\hline Uncoded & $35 \%$ \\
\hline Sport-for-development & $7 \%$ \\
\hline Partnerships & $11 \%$ \\
\hline COHM Tenets & $47 \%$ \\
\hline
\end{tabular}

In recognizing that a large portion of uncoded data were reflected in the literature review portions of academic evaluations, it appeared, despite the relatively low percent presence of the main categories, that the data successfully reflected main category presence in the majority of the documents' content (65\%) regarding organizational efforts. Due to the lack of presence of other substantial themes within coding, it can be concluded that the $47 \%$ presence of the COHM tenets was a meaningful presence. 
Quantitative presence of individual COHM tenets. In order to fully answer RQ\#1, the extent to which organizations reflected the COHM tenets, I broke each tenet's presence down across organization. Figure 2 represents the presence of each individual COHM tenet, in the all types of document, for each organization.

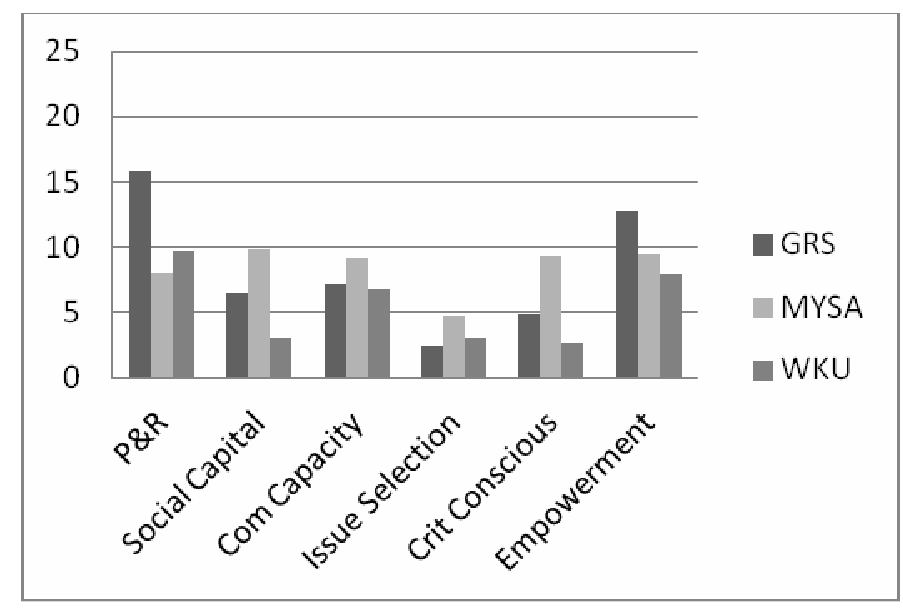

Figure 2. Percent Presence of Individual COHM Tenets. Reflects the presence of each tenet in all of the documents coded for each organization.

As seen in the above trends, the data reflect a greater presence of COHM tenets in the documents of Grassroot Soccer and Mathare Youth Sports Association compared to WhizzKids United, as seen in Table 4 . The results across tenet also clearly reflected the code least represented in the material- "issue selection." It is relevant to note that I created a bias while using this code in the analysis, as it was one of the coding categories with the most potential to overlap with other tenets. Due to the fact that "issue selection" was difficult to separate from "community capacity" issues (due to the need to realistically select a goal that fits the community's current capacity) and "participation \& relevance" (selecting a goal that is culturally relevant/builds community ownership), I often did not code "issue selection" when it appeared in a section with one of these two codes. Rather than double code multiple pieces of the literature, I decided to code each 
unit as the most relevant code. My analytic memos reflected the areas where I made this decision to not double code "issue selection."

While none of the individual tenets represented more than $15 \%$ of the total data for a single organization's documents, the number of units coded, reflected a meaningful presence of every COHM code. As was reflected in Figure 2, "issue selection" only represented $2-4 \%$ of the total codes for any organization; however, I still coded it no less than 20 times for each organization. For this reason, even the least coded tenets exhibited a repetitive presence as a theme in each organization's documents. Table 5 represents the number of times I coded each main category tenet in promotional documents.

Table 5: Number of Codes for Each COHM Tenet

\begin{tabular}{|ccccccc|}
$\begin{array}{c}\text { Total \# } \\
\text { of }\end{array}$ & Empowerment & $\begin{array}{c}\text { Critical } \\
\text { Consciousness }\end{array}$ & $\begin{array}{c}\text { Issue } \\
\text { Selection }\end{array}$ & $\begin{array}{c}\text { Community } \\
\text { Capacity }\end{array}$ & $\begin{array}{c}\text { Social } \\
\text { Capital }\end{array}$ & $\begin{array}{c}\text { Participation } \\
\text { \& Relevance }\end{array}$ \\
\hline GRS & 107 & 41 & 20 & 60 & 55 & 132 \\
\hline MYSA & 91 & 90 & 45 & 88 & 95 & 122 \\
\hline WKU & 65 & 22 & 25 & 56 & 25 & 79 \\
\hline
\end{tabular}

These results reflect the beginning of the answer to the first research question poised for this study. All six COHM tenet themes appeared on a recurrent and consistent basis in all of the coded documents. Even though the model showed a strong quantitative presence, the presence of each of its tenets was most poignantly displayed when examining the qualitative content of each organization's literature.

\section{Qualitative reflection of COHM tenets.}

Empowerment. As exhibited in Table 5, the "empowerment" codes showed a strong presence in each organization's materials, second only to the "participation and relevance" category. I set the "empowerment" code to encompass four different areas of 
a participant's experience: 1) building self-efficacy/competence, 2) building knowledge/achievement, 3) creating mastery of self/personal responsibility and 4) inspiring hope for the future. While all four of these subcategories are inherently interwoven in the concept of empowerment, they were differentiated due to their individual roles in the process of empowering individuals (Tengland, 2007). When youth seek to build knowledge and skill and are provided opportunities to apply that knowledge and skill, they have an opportunity to develop self-esteem, efficacy and confidence in their ability to appropriately respond to a situation that would put them at risk for contracting HIV. This confidence and knowledge allows them to take ownership and responsibility for their actions. In turn, this "mastery of self and responsibility" aids youth in planning for and envisioning a future that moves beyond the shadow of HIV (Minkler \& Wallerstein, 2002, p. 288).

From evaluating the promotional materials of WKU, GRS and MYSA, each organization strongly reflected the process of developing empowered youth, toward the end goal of creating an empowered community. The beginning of this process involves helping participants to increase their concept of self-worth and competence. One Grassroot Soccer participant stated that GRS "really helped me to be myself. It has helped me to show my own story, my spunk, my style and how to be real with the kids" (Grassroot Soccer, 2012). The ability to express themselves and grow in comfort level, within the athletic environment, helps the youth involved develop feelings of self-worth and competence. This feeling of value and competence helps the youth become more engaged in the program: 
Joining MYSA changed my life. It increases self-esteem and encourages people to conserve the environment. I developed confidence, ambition, and a sense of self-worth. I have learned new skills and won scholarship to pay my school feeswithout this, I would probably already have left school (Mathare Youth Sports Association, 2011).

Indeed, the development of self-esteem and self-efficacy naturally pairs with creating the motivation to further knowledge and skill about life skills and HIV education. One evaluator visiting the MYSA community commented that: "All the young people at MYSA appeared confident and happy and all those I met apparently strove hard to succeed, both in their education and in MYSA sporting and non-sporting activities (Woodcock, 2007, p. 3).”

The potent effect of empowering youth through building self-esteem, competence and knowledge about HIV risk situations comes to fruition when youth take control of their life situation. One WKU participant commented about taking ownership of his HIV status:

My name is Sepo, and I am 15 years old. I like to come here (to WhizzKids United), because I can get proper education about my health. My personal situation is that I am HIV positive, and I told myself now that I know my designation; I need to take responsibility for myself. I need to live in this world like other people. If WhizzKids did not exist, I would have been dead by now (WhizzKids United, 2012). 
Another participant of Grassroot Soccer, Susan Bulaya, reflected: "[Because of the program] now we know we can cure HIV/AIDS with our knowledge and power. Thank you Grassroot Soccer" (Grassroot Soccer, 2011).

One of the keys for empowering youth to take responsibility for their lives appears to be the chosen method of implementation:

Grassroot Soccer has done a really good job of giving people the tools of saying 'Okay, you understand this is a problem, here are the skills and a toolkit that you can use to really help you make decisions about your own life- to protect those around you.' [We] are not standing in front of kids and telling them what to do and giving them behaviors that they have to follow, but rather presenting ideas to them- giving them information and asking them to make decisions in their own lives" (Grassroot Soccer, 2012).

The ability to feel that they have some measure of control over the impact of HIV in their lives, oftentimes is the catalyst for reawakening hope and optimism in youth lives. One doctor at the WhizzKids Health Academy summarized it by saying: "When you look at these children, and actually empower them, you give them plans for their future, you give them hope" (WhizzKids United, 2012).

The overall aftereffect of youth becoming educated and empowered to control their own lives and HIV status, is the dissemination of these same characteristics to the greater community. WKU's promotional materials reflected this end goal: "The program gives kids a sense of pride and achievement and gains them recognition within their community (Africaid, 2009, p. 18). This recognition opens the avenue for youth to feel comfortable sharing what they learn with others in the community, an idea that 
crosses over with the tenets of social capital and building community capacity. It also makes youth more liable to engage in dialogue about HIV's effect on the larger community- the concept of critical consciousness.

Critical consciousness. The concept of critical consciousness, a natural outcome of empowering individuals, appeared to varying extents across each organization's documents. MYSA was the only organization that reflected a strong presence of critical consciousness in all types of documents examined; however, each organization did promote the importance of "critical consciousness" dialogue in each of their programs.

Critical consciousness refers to "consciousness based on reflection and action in making change” (Minkler \& Wallerstein, 2002, p. 288; Minkler \& Cox, 1980; Wallerstein \& Bernstein, 1988); as such, I coded it under three categories for this data analysis: 1) dialogue around awareness, 2) dialogue about political/social realities and 3) identifying practical solutions. Discussion is a critical aspect of inspiring and managing any community change. It was clear in the content of each organization's documents that empowering youth was not enough to make a sustained impact; programs needed to tie this empowerment to awareness and discussion of life circumstances. Indeed, each organization plans this discussion into the structured setting of each of their programs. WhizzKids United places their focus on creating awareness by exposing youth to resources at an early age:

Africaid believes that by facilitating open communication about HIV/AIDS among adolescents, and establishing regular voluntary counseling and testing (VCT) as a social norm, stigma and its effects on HIV transmission can be lessened. This is a further reason why WhizzKids United works with kids as 
young as 11 - they are of an age where stigmatizing beliefs, if they exist at all, are still impressionable (Africaid, 2009, p. 18).

Grassroot Soccer aims to increase awareness by involving the participants' community in the concluding "graduation" events for its programs:

Once the students have completed the two-week HIV/AIDS workshops GRS holds a formal graduation for the students involved. GRS encourages both the role models and children to invite their families and friends to attend. By doing so, GRS is attempting to involve the communities in this venture with the hope that they will become more involved in the education process and encourage communities to become comfortable with discussing the issues surrounding HIV/AIDS (Griffths, 2005, p. 23).

As GRS mentioned, the goal of awareness measures is to help open the community to engaging in dialogue; however, this dialogue must acknowledge the social and political realities of the culture. MYSA aims to build a creative forum for critical consciousness dialogue, that breaking cultural taboos around discussing HIV, through plays and musical events:

Every Saturday our Haba na Haba project holds a two hour Participatory Educative Theater show in a public space in one of the zones. The aim is raise awareness amongst people in the communities where we live about important social issues such as HIV/AIDS, alcohol and drug abuse, and gender equality. Audiences from local communities come along and work with the performers to decide how the problems or issues that are highlighted should be resolved. Often there is a lively debate and Haba na Haba peer educators and counselors have the 
opportunity to talk in more detail about the issues raised (Mathare Youth Sports Association, 2011).

Building awareness and discussing the social and political environment of the culture helps lead to informal conversations regarding possible solutions. GRS discovered that participants frequently brought this discussion to their home and school community:

Evidence from focus groups also suggests that participants are talking about HIV/AIDS with their peers. At Tlhabologo Primary School, all participants in a post-program focus group reported that they talked about GRS with friends and about half had talked about GRS with family, even though some parents were reluctant to talk about HIV and sex with their children (Grassroot Soccer, 2006, p. 1).

I shared with my classmates about my aunt and her disease. I even cried. But they [my classmates] supported me. I told them that we must fight this horrible disease. As citizens of Botswana, it's important that we teach our friends... Since GRS, we feel comfortable talking about HIV (Grassroot Soccer, 2006, p. 8). MYSA reflected that initiating conversation serves as a way to informally gather pivotal groups of individuals in the society, specifically the female population, most at risk for contracting HIV:

A team of female volunteers has set up the Girls' Forum, which meets every Sunday to discuss issues of importance to young women and girls and to support each other in their work. They seek advice from each other on how to deal with 
situations encountered amongst girls; how to counsel young women about pregnancy, abortion and rape, for example (Woodcock, 2007, p. 17).

The presence of the "critical consciousness" code reflected the idea that the mere existence of these HIV football-for-development programs was often enough to enhance awareness and begin valuable dialogue in the community; however, for critical consciousness dialogue to actually make an impact, the football-for-development communities needed to: 1) feel ownership of the issues, 2) understand the method of response, and 3) feel that the community was putting forth a cooperative effort to solve the problem.

Issue selection. Issue selection is a pivotal concept in relation to settling on a realistic method of implementation to address urgent community issues. It refers to the ability to "identify winnable and specific targets of change that unify and build community strength" (Minkler \& Wallerstein, 2002, p. 288). These issues are primarily identified through a democratic forum with the community; however, a leader should be present to focus attention on the issues that are most realistic to achieve.

"Issue selection" presented itself as an interesting coding category given two of the three organizations under study did not employ full local leadership for their programs and were funded primarily through outside, international partnerships. This meant that issue selection could have been influenced by concepts and stipulations separate from the community input. As such, I divided the "issue selection" coding category into three different subcategories: 1) issues based upon academic research and recommendations, 2) issues based upon community dialogue, and 3) strategic goals that 
would allow the community to achieve its goals and enhance the reach of the organization.

The academic research issues subcategory was meant to span any reference to HIV related research, HIV best practices, Millennium Development Goals or other recommendations of issues from external sources for development efforts. The community-specific issue subcategory was meant to define issues brought into implementation due to consultation from the community. Finally, the strategic goal subcategory was meant to encompass the strategic goals each organization developed for the growth and forward movement of the organization. In examining the structure of these three subcategories, it is clear to see the bias I mentioned earlier: the overlap of these concepts with other tenets. In theory, I could have coded all parts of the organization's strategic plan documents as the third subcategory, but I decided to code each part of the strategic plan separately, as it related to any other relevant codes.

Even though the presence of the "issue selection" code appeared to be under exaggerated in the coding results, it was clear that the football-for-development organizations reflected a desire to incorporated both internal and external recommendations within their implementation efforts. External input often came from international governing bodies:

This program has been developed in light of the latest research and consolidated through years of on-the-ground experience...The vision of Africaid's WhizzKids United is to create an HIV/AIDS-free generation in Africa. Africaid agrees with former South African Minister of Health Manto Tshabalala-Msimang that, "In the 
absence of a cure, prevention has to be the mainstay in the struggle against AIDS" (Farrar \& McGilvray, 2009, p. 9).

This input often ensured that each organization focused efforts toward growing the involvement of female youth: "In response to overwhelming research promoting the value of girls' participation in sport, coupled with the need for effective HIV prevention, GRS launched Skillz Street in early 2010” (Grassroot Soccer, 2011).

However, each organization recognized the need to balance recommended areas of focus with community-owned issues to achieve community ownership and sustainability. For this reason, each organization also reflected the desire to engage the community in addressing issue selection. This community engagement took the form of empowered participants focusing on creating dialogue and serving in leadership roles:

The spread of HIV/AIDS is one of our toughest challenges. In fact, young people between the ages of 14 and 24 are particularly vulnerable because we often don't know what to do to protect ourselves. Our parents have very little time to spare as they work so hard to earn a living and free time is not spent discussing sexual health. This is why we, as peer educators, play such an important role within the community (Mathare Youth Sports Association, 2011).

'HIV is such a major challenge for young people in this part of the world. Everyone that I know is affected one way or another, even if you are not infected. As I was being brought up I was affected. I had relatives that passed away due to the disease. That was one of the things that really inspired me to say, 'We need to do something to address this'- GRS Participant (Grassroot Soccer, 2012). 
In combining the voice of non-local and local stakeholders, each football-fordevelopment organization constructed and refined a strategic plan to address HIV prevention in their respective communities. These strategic plans, combined with community input into program direction, assist each football-for-development organization in building positive relationships between community members.

Social capital. Minkler and Wallerstein (2002) defined these cooperative relationships between community members, defined by trust, reciprocity and civic engagement, as social capital Communities with social capital are better able to move together for the mutual benefit of the community, creating a strong feeling of community identity (Campbell, 2001; Coalter, 2010a; Delva \& Temmermen, 2006; Kreuger et al., 1997). MYSA nicely sums up the idea of establishing social capital:

At its most fundamental level MYSA is a community action group that draws in young people and enables them to make viable contributions to public life. Its broad agenda embraces a commitment to education, to the active and meaningful civic participation of its members, and to the creation of a cadre of talented young people with an interest in the larger world (Brady \& Banu Khan, 2002, p. 9). MYSA further reflects the importance of social capital in its guiding slogan: "If you do something, MYSA does something; if you do nothing, MYSA does nothing" (Mathare Youth Sport Association, 2011). However, MYSA was not the only footballfor-development program to recognize the impact of strong social capital. WKU identified that an increased level of trust and reciprocity in relationships improved the odds that meaningful social change could occur as a result of programs: 
The goal was to deliver a program that meets the community's needs (and that of its participants - in this case HIV/AIDS education). In addition, the construction of a social bond based on mutual trust enables positive interactions with the community that was then translated into an effective partnership that monitors the program's implementation, evaluates the outcomes and suggests recommendations for its improvement (Azzopardi, 2010, p. 58). GRS' recognition of social capital appeared in the words of local leaders implementing the program. One coach reflected upon the way the program changed the youth's concept of him: "I don't think they look at me as this 'English teacher' who they can't relate to, but someone who pals around with them and is right next to them in the strong circle," and another commented on the effect of local leaders on youth:

You know there are kids that look up to you. They see you every day going to training and they like that from you. You are in it together, and everything you say has got an influence to them (Grassroot Soccer, 2012).

The far reach of meaningful community relationships was dotted throughout each organization's promotional materials, whether in discussion of the effect of community role models (GRS), the identification of community members that could provide trusted support (WKU), or in the intentional offering of leadership award points for acts of civic engagement (MYSA).

MYSA's understanding of the potent effect of social capital offers a bridge into the tenet of participation \& relevance:

MYSA actually belongs to the people of Mathare, and this is key to why it is respected. 'Building walls keeps people out', whereas the aim is to 'build a 
community in which nobody steals from an organization from which your brothers or sisters could benefit' (Woodcock, 2007, p. 37).

Participation and relevance. It is no surprise that each organization reflected the most coded categories within the "participation and relevance" code. Each organization has grown since its initial pilot programs; as such, the promotional materials for all football-for-development organizations should rationally promote the efficacy and relevance of their programs. I broke the "participation and relevance" main category into: 1) culturally appropriate implementation, 2) community ownership/management, and 3) monitoring \& evaluation. After editing the pilot codebook, I restricted "participation \& relevance" to the above subcategories, in relation to commentary about the actual effectiveness/evaluation of implementation efforts rather than speculated or intended relevance.

As is clear in the rationale for using sport as a development tool, sport offers the potential to engage youth in a culturally relevant way. Each organization chose football as the primary sport through which to design their HIV prevention efforts. One GRS coach described the relevance of football programs in this way:

Soccer is the hook. We get them there, and all of a sudden we blast them with these fun games that aren't necessarily sports oriented but they relate to HIV and AIDS. Pairing the learning process with activity doesn't feel like traditional learning” (Grassroot Soccer, 2012).

However, the easy "hook" of football does not ensure that all elements of the program design are culturally appropriate. Each organization utilizes different program designs in an attempt to make their programs reflect cultural relevance, as was evident in the 
passages coded under this subcategory. MYSA works on relevance by ensuring their programs are easily accessible to the youth of Mathare: "Any youth in the Mathare and neighboring slums can become a member by joining a local MYSA team or project. As their families are far too poor, there is no membership or other fee" (Mathare Youth Sport Association, 2011). MYSA also varies the content of their programs, depending upon the age of the participant:

Peer educators use lots of different methods. For children of primary school age, we use the Kicking Aids Out method, which integrates sexual health issues into the sport or games already being played. Older children take part in discussions and workshops involving more sophisticated concepts and language (Woodcock, 2007, p. 32).

WKU also utilizes peer education as a tool for tailoring a more relevant message. One WKU teacher described the program's effect as such:

Peer education is very good, because these kids are their own age; they are teaching other kids their own age. It is really good for them, because sometimes they don't come to me and ask such things like: 'If I am having sex, what if I have a problem like this?' or 'Why must I have sex?' So, these questions they can ask their peers, and it is easy to communicate with them. Sometimes they are scared of asking their teachers, so when they have peer educators in their class, it is easy to talk and be communicated with (WhizzKids United, 2012).

WKU is also the only one of the three organizations that seeks to maintain a long standing partnership with local schools, running their program directly within the 
curriculum of the schools. This partnership helps to create sustainability with the curriculum:

For purposes of practicality and sustainability, the WhizzKids United program has been designed to fit into the Life Orientation curriculum in South Africa. Life Orientation is a subject mandated for all learners nationwide, and WhizzKids United meets all of the learning outcomes defined in the curriculum, namely health promotion, personal development, social development, and physical development \& human movement. WhizzKids United is therefore ideally suited to make the best out of school time as the primary forum for youth HIV prevention interventions (Farrar \& McGilvray, 2009, p. 14).

MYSA, GRS and WKU all work toward developing community ownership of their programs. While MYSA leads the way on this approach, due both to the original design of the program (owned and run by the youth) and the program's length of existence (24 years), each organization's materials exhibited commentary about the community's ownership of their programs:

MYSA is owned and run by the youth. In the 16 MYSA zones, key decisions are made by locally elected youth leaders. The best leaders are elected to the overall MYSA executive bodies. The average age of our several hundred MYSA volunteer organizers, leaders, coaches and referees is 15-16 years (Mathare Youth Sport Association, 2012).

(GRS) is not your typical competitive football team. The football players and families take pride in their community and working with kids and doing other things than winning on the soccer field. Some of the players also coach for 
Grassroot Soccer, so it has been a really good fit working together (Grassroot Soccer, 2012).

It can be noted that overall, research participant perceptions establish WKU's positive contribution to the developmental path of individual participants and the communities they belong to. This is especially visible in the replies penned by parents, educators and program facilitators to questions set-out to them in questionnaires. The respondents listed "keeping young people out of bad habits", "providing a safe environment for recreation and learning" and "adopting healthier lifestyles" as the main reasons for their approval of the program (Azzopardi, 2010, p. 43).

Finally, due to the sustained presence of each football-for-development organization, and its connection to sustainable partners, discussion of "monitoring and evaluation" appeared frequently as a relevant theme under the "participation and relevance" tenet. Each organization reflected the theme of integrating their curriculum development and implementation with community feedback:

Our curriculum development process has been informed by years of field experience and technical expertise in curriculum design. Grassroot Soccer produces culturally relevant curricula by closely engaging local stakeholders in Curriculum Development Workshops. This workshop is designed to elicit input and direction from youth, mentors, and local coordinators to guide content development and delivery (Grassroot Soccer, 2011).

MYSA began simply, yet over the years it has refined its goals and programs in response to the changing needs and interests of the community it serves-a 
testament to its institutional resiliency. This changing focus can be seen in the enhanced number of programs (Brady \& Banu Khan, 2002, p. 29). In order to maximize effectiveness, (WKU's) health academies are "guided by an advisory board made up of the children themselves, educators, parents and community members to ensure that specific community needs are accounted for and the necessary precautions taken to provide a healthy and safe environment for the beneficiaries and care takers alike" (Azzopardi, 2010, p. 41).

Community capacity. The community capacity category was the only one of the tenets reflected roughly equal across each organization. It was clear that each organization valued the concept of "enhancing the characteristics of community affecting its ability to identify, mobilize, and address problems" (Minkler \& Wallerstein, 2002, p. 288).

In coding for its presence, I divided the "community capacity" code into four subcategories for evaluation: 1) the ability to access resources, 2) the ability to mobilize the community into action, 3) the formal and informal shared expertise of community members and 4) the skills and education necessary to enhance the community capacity to act successfully. While there was a consistent presence across organizations, the category of "community capacity" showing the most unedited bias in the codebook, due to the similarity between the definitions for the "shared expertise" and "skills and education" subcategories. I did not clarify in the codebook that the "shared expertise" subcategory was to reflect the current capacity and the "skills \& education" subcategory was to reflect future plans for increasing the community's capacity through skills and education. I noticed the similarity in definitions in an analytic memo mid-way through 
the final coding process, when I caught myself coding similar passages interchangeably with these two subcategory codes. By that time, I made the decision to continue attempting to differentiate between the two categories but recognized the need for all units coded as either subcategory to be revisited to clarify the accuracy of the codes.

Since community capacity is dynamic in nature, a program should ideally address all areas of growth capacity in their efforts (Goodman et al., 1998). However, due to the difficulty of addressing all areas of capacity growth at once, this main category reflected a distinct difference in the frequency of each subcategory across organizations. Due to WhizzKids United's strong focus on their Health Academy and drive to get kids tested, they reflected a much higher percentage of codes within the "access" subcategory than the other two organizations:

WhizzKids United Health Academy is our adolescent-focused health centre that offers the best in HIV counseling and treatment, management of sexually transmitted infections (STI), antiretroviral (ARV) treatment and youth guidance. Furthermore, the Health Academy also provides many great after-school resources for the youth such as activity-centered clubs, academic support groups and our very own Mixed Gender Football League (WhizzKids United, 2011).

GRS' and MYSA's efforts, directed toward enhancing educational opportunities, led to a larger percentage of their codes to fall within the "skills and education" subcategory:

Learning is not a spectator sport. Adolescents retain knowledge best when they are active participants in the learning process, teaching others what they 
themselves have learned. Grassroot Soccer graduates are trained to become peer educators and advocates in their communities (Grassroot Soccer, 2011). MYSA would rather train a promising young leader to gain the requisite skills (football coaching, refereeing, photography, accountancy, librarianship, management, public relations, counseling, driving etc.) than to bring in someone from outside to join the staff (Woodcock, 2007, p. 12).

Despite the subtle differences in focus of the community capacity efforts, each organization did appear to value creating opportunities for each football-for-development community to become better equipped to address the issue of preventing HIV in their community.

Summary of COHM tenet presence. As is reflected in the previous six sections, each of the football-for-development organizations under investigation actively reflected themes and values in their organization's promotional material that reflected each COHM tenet; however, the one theme recommended for evaluation and present in all of the documents, that was not specific to one COHM tenet, was the theme of partnerships for sustainability.

Additional theme: Enhanced partnership for sustainability. The importance of partnership is peripherally encompassed within multiple COHM tenets; however, within this analysis, the theme was strong enough to merit its own coding category. Figure 3 reflects the quantitative presence of the partnership coding category in relation to each of the COHM tenets. 


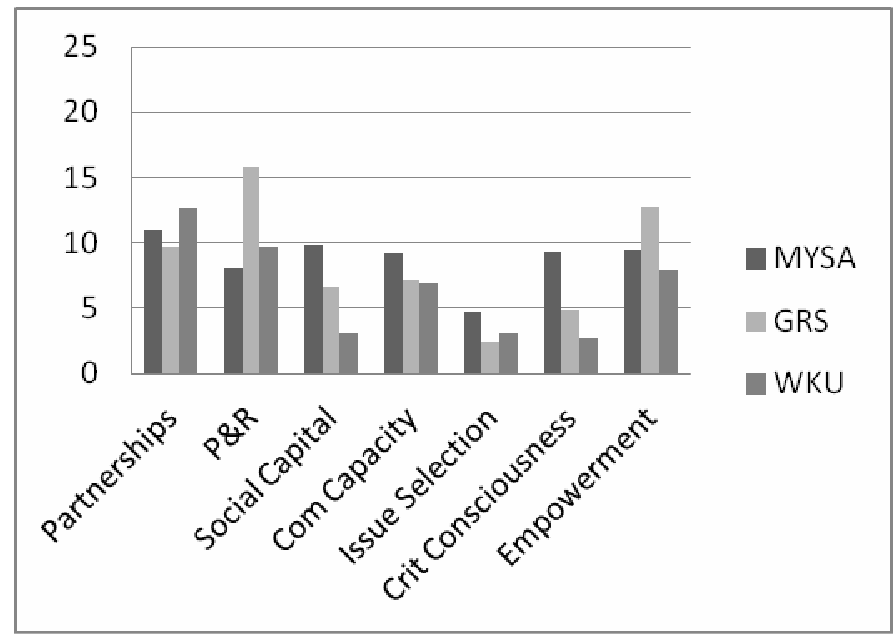

Figure 3. Presence of Partnership Code Compared to the COHM Tenets.

The focus on partnerships for sustainability and resources was reflected in its high presence compared to other COHM tenets. Partnerships are pivotal pieces to sustaining programs. Partnerships offer a spectrum of resources to local community efforts, including the six areas emphasized as subcategories for this theme: 1) partnership for advocacy, 2) partnership to enhance material resources, 3) partnership to enhance knowledge resources, 4) partnership to enhance political/power resources, 5) partnership to assist in ideas for growth and 6) partnership with relevant football development organizations, including FIFA's CSR focus and streetfootballworld's unifying network.

\section{Research Questions \#2-4: The COHM Tenets and Recommendations for}

\section{Standardizing Evaluation}

RQ\#2-4: To what extent are the organizations establishing community ownership?

\section{Cultural relevance? Sustainability?}

The content analysis performed on the Grassroot Soccer (GRS), WhizzKids United (WKU) and Mathare Youth Sports Association (MYSA) documents reflected the tenets of the Community Organization Health Model (COHM), showing that the building 
blocks of the COHM could be suitable to use in the creation of an evaluation procedure. However, the individual tenets did not directly correlate with the three recommended areas of evaluation: cultural relevance, community ownership and sustainability \& partnership. The broad definition of these areas made it more relevant to evaluate an organization based upon the extent to which it reflected all coding categories related to this area. For this reason, I collapsed all of the relevant coding categories to determine the extent to which each organization currently reflects each of the recommended areas for evaluation.

Relevance. (Empowerment + Critical Consciousness + Issue Selection + Participation and Relevance). I included empowerment in relevance, as neither an individual nor the community can take relevant action, nor discuss its problems without being empowered to control its own future. Empowerment of community members innately leads to critical consciousness discussions of the issues at hand, making this dialogue valuable in ensuring relevance. Issue selection focuses on evaluating where the community is at present and setting goals the community deems to be relevant. Finally, the participation and relevance tenet reflects the community's intentionality to stay accountable with implementation procedures. In addition to their meanings, I also collapsed the above categories due to their prevalent appearance in units that appeared under the key word searches for "relevance," "accountability," and "culturally appropriate implementation."

Ownership. (Issue Selection + Community Capacity + Social Capital + Participation and Relevance). I chose issue selection to reflect ownership, as part of issue selection involves the ability to connect community goals with the individuals who offer 
the capacity to help achieve them- namely members of the community. The community capacity, however, affects whether or not the community as a whole feels empowered to own the problem and act to create a solution. Pivotal in any community project is the ability to build strong, meaningful relationships of trust and reciprocity. For this reason, I also included social capital in the collapse of this category. Finally, the chosen issue and methods of implementation must be confirmed relevant to the community, through evaluation and monitoring, in order to maintain their participation. The key word search to identify relevant categories included searches for "ownership," "community involvement," "local leadership" and "culturally appropriate implementation."

Sustainability. (Social Capital + Participation and Relevance + Community Capacity + Partnerships). As with ownership and relevance, if a program does not have a community where trusting relationships are present and relevant issues are addressed, the program will not have the support to be sustained. Community capacity plays a large role in the ability of a community to sustain any effort to address problems, as it accounts for current capacity and plans for growth, including highlighting areas where the community could benefit from partnerships. Partnerships, especially in the activity of international NGOs, play a pivotal role in the sustainability of resources and programs. The key word search for sustainability categories included "partnership," "sustainability," "growth," “capacity," and "culturally appropriate implementation." 


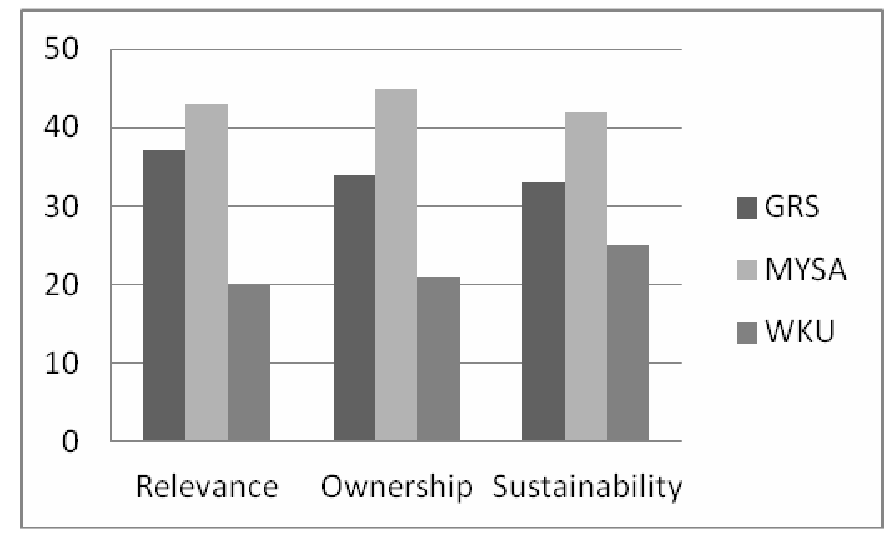

Figure 4. Percent of Coded Documents Reflecting Areas of Recommended Evaluation. This figure illustrates coding categories collapsed to reflect areas of recommended evaluation.

In answer to RQ\#2-4, Figure 4 shows each organization reflected a moderate amount of focus on each of the recommended areas for standardizing evaluation, based upon the themes present in their promotional documentation. As is clearly exhibited in the breadth of the COHM tenets, the recommended areas of evaluation can be fully encompassed by the collapse of multiple tenets.

\section{Summary of Results}

From the content analysis results of all four research questions, it stands to reason that all three best practice organizations reflected the COHM tenets and partnership codes to a meaningful degree. They also all appeared to reflect an effort to address the three areas recommended for evaluation. While none of the organizations reflected a perfect match to all of the COHM tenets or recommended areas for evaluation, each organization did reflect certain subcategories in which it excelled. For this reason, the breadth of the COHM could span the distance of varying cultures, to assist in the exchange of best practice information within each tenet area across football-for-development organizations. The COHM may also provide the ability to allow organizations to 
improve areas of weaknesses based upon the strengths exhibited from other organizations, without losing the unique style of their individual program's community work. For all of the above reasons, the COHM appears to be a promising fit to create a uniform evaluation for football-for-development programs. 


\section{Chapter 5}

\section{Discussion}

"Football is more than just a sport. It is emotion, it is passion, it is defeat and it is success. For some people it is their whole life; and for some people it can change lives."

(WhizzKids United, 2011)

HIV is a pandemic with an immense and lasting impact, a pandemic that the United Nation (UN) states can only be dealt with through a coordinated effort (The Global Fund, 2011; World Health Organization, 2006). For years, medical researchers focused on attempting to treat and find a cure for the disease. In the absence of a cure, the recent focus has been directed to preventing further spread of the disease, particularly in the most susceptible population- youth (Botcheva \& Huffman, 2004; UNAIDS, 2010; World Health Organization, 2011b).

During the early 2000s, non-governmental organizations (NGOs) worldwide began using sport in an innovative way- as a means toward development (Right to Play, 2008; United Nations, 2003). In relation to HIV, a number of NGOs utilize the power and popularity of football, to teach youth about HIV prevention and increase their access to much needed testing and treatment resources (FIFA, 2011a; streetfootballworld, 2011).

Due to the growth and development of this means of prevention, I based this analysis off of the assumption that football-for-development programs are an effective means of addressing HIV prevention in youth. This assumption provided the context for the main study problem: the lack of a uniform procedure for sport-for-development evaluation measures. The primarily qualitative and subjective evaluations of efficacy produced in recent years have brought sport-for-development organizations under 
scrutiny due to the lack of consistency in implementation and accountability (Coalter \& Taylor, 2010c; Levermore, 2008). Researchers and funders alike want to know whether these programs are truly a viable and valuable resource to keep supporting as a development tool. In the development of a standardized protocol, it is recommended that organizations focus on three primary content areas: cultural relevance, community ownership and partnership for sustainability (Brunelli \& Parisi, 2011; Coalter \& Taylor, 2010c; Levermore, 2008).

The challenge of creating a uniform evaluation procedure across all sport-fordevelopment program lies within the vast differences in focus (e.g., sport-for-peace, sport-for-education etc.) as well as the varying cultures in which these programs function (Right to Play, 2008). Due to these unique challenges, a potential model for evaluation needs to reflect the flexibility to apply across various cultural contexts. Due to its breadth, community centered focus and perceived flexibility, the Community Organization Health Model (COHM) was thought to be a potential model from which a uniform evaluation for these programs could be formed.

The COHM framework attempts to help communities identify common problems, mobilize resources, and implement strategies for reaching their collective goals, including building valuable partnerships (Minkler \& Wallerstein, 2002). In addition, its focus on the community and harnessing cultural change makes it a promising model from which to highlight and amplify the positive effects of sport on the community and individual. The COHM's overall framework provides a fit for football-for-HIV-development organizations and offers the utility to bridge across multiple cultural contexts, due to its emphasis on tenets that could be established in any community. However, a model is 
only useful in creating evaluation measurements to the extent that the organizations under evaluation reflect the values and tenets of that model in their implementation procedures (Glanz et al., 2008).

Therefore, the purpose of this study was to use content analysis to examine the promotional material for three best practice football-for-HIV development organizations to see if the promotional material reflected the presence of the COHM tenets. I assumed the promotional material, accessible to anyone interested in the organization, should reflect the concepts the organization finds to be most critical to the functioning of its programs. Therefore, if the documents of multiple organizations reflected the tenets of the COHM, the model would not only be a good fit for creating an evaluation based on research recommendations, but it would be a good fit based upon the actual activities and intentions of football-for-HIV development organizations.

\section{Key Findings}

The analysis uncovered two primary findings: 1) there was a meaningful presence of the COHM in best practice football-for-development documents and 2) the additional code of "partnerships" showed a meaningful presence in the promotional documents.

Using qualitative coding procedures, the analysis resulted in roughly $47 \%$ of the coded material, across all three organizations, reflecting the COHM tenets. Due to the external and internal evaluations, written for an academic audience, included in this study's documents, there was a large portion of the content that remained uncoded, as it did not directly discuss organizational efforts. However, the purpose of the inclusion of each type of document (internal, external and promotional) was to determine if the 
organizations: 1) claimed to value the COHM tenets and partnership, 2) showed they valued these codes through internal evaluation and 3) reflected an external view that their organizations reflected these codes. Indeed, each organization reflected COHM tenet presence in each type of promotional document.

While the COHM tenets strongly encompassed the recommended areas for evaluation-relevance, ownership and partnership- they did not fully address the importance of local and international partnerships. For this reason, a main category code of "partnerships" was created for the analysis. This code reflected a presence that matched the most prevalent COHM tenets, reflecting the value each organization saw in building partnership connections. Due to the "partnership" coding categories strong presence, it is recommended that additional evaluation questions focusing specifically on creating partnerships be added to an evaluation procedure created from the COHM.

\section{Limitations}

While completing the study, I logged notes about limitations and areas of bias in analytic memos. The first of limitation noted was a limitation on the type of material explored. While I made an attempt to equalize the type and length of the documents examined from each organization, I ultimately chose the articles, internal evaluations and external evaluations based on the inclusionary criteria set for the analysis and an approximately equal unit length to the other documents of that type. I was able to show that saturation was achieved with the documents; however, this partially randomized pull

of documents from the organization's websites could have altered the level of presence of one or more of the COHM tenets. While I do not believe this limitation area would have 
affected the presence or lack thereof a tenet, it could have enhanced or detracted from the extent to which a code was emphasized in the evaluations/promotional content.

Another area of potential limitation came in with my personal biases as a researcher. Since I performed this analysis with a qualitative protocol and interpreted it qualitatively, the conclusions are subject to the biases formed in creating the justification for this analysis. Since I deemed the COHM offered the most potential for both footballfor-development programs and HIV prevention programs, I was more inclined to read into the content to pull out the meaning of each coding unit rather than code solely based upon the codebook definitions. This tendency was discussed in the process of refining discrepancies in the coding of the pilot codebook. Due to the knowledge of this bias early on, I controlled for it as much as possible by: 1) coding the documents in small chunks (to remain attentive), 2) performing intra-coder reliability measures, and 3) attempting to add rigor to the codebook development. I hoped that by quantitatively validating the codebook, another researcher could code the same documents and come to a similar conclusion about the level of presence of each code.

Editing and validating the reliability of the codebook also caused potential bias areas within the coding of categories. Due to the breadth of each of the tenets in the COHM, and the extent to which they overlap and relate to one another, I had to limit the scope of some of the tenets in order to add clarity and distinction between categories. This bias was introduced to reduce the number of categories that were double coded. This bias primarily occurred within the "empowerment" and "participation and relevance" sub-categories, and in recognizing that "issue selection" was often not doubled coded where relevant. 
Finally, I could have strengthened the analysis by expanding the role of the secondary coder, to code more of the final data as a check to my biases. The secondary coder served primarily to reach an acceptable level of agreement with the codebook, but the analysis did not reflect another researcher confirming the conclusions derived from the coding results; however, due to time and personnel availability restrictions, this extended secondary coder role could not take place. It stands to reason, with the available finalized codebook (Appendix D), that another researcher could validate these findings at another point in time.

\section{Practical Implications for Findings}

This study analysis was undertaken as there remains a clear need to establish a generalizable and uniform method of evaluation for sport-for-development programs. Specifically, sport-for-development programs that appear to be contributing to the prevention of HIV in high risk countries. I chose the COHM as the model for this exploratory analysis due to the following reasons:

1) The model fits well into the aim and proposed benefits of sport-fordevelopment programs (United Nations, 2003; Right to Play, 2008);

2) Some of the model's tenets have played an important role in the success of HIV prevention efforts (Campbell \& McPhail, 2002, Campbell et al., 2005; Gregson et al., 2004; UNAIDS, 2008);

3) The model's breadth of categories and focus on community relevance provides the utility for its use across different cultures and programs (Minkler \& Wallerstein, 2002); 
4) The model's tenets comprehensively encompassed all three areas of recommended evaluation: cultural relevance, community ownership and sustainability measures (Coalter \& Taylor, 2010c; Levermore, 2008); and

5) Upon a preliminary, a priori, reading of promotional materials for best practice football-for-development organizations, the model appeared to be reflected in the value of each of these organizations.

It stands to reason that an organization's full promotional materials and printed evaluations would reflect the values behind the structure and implementation of its program. This qualitative analysis showed that the COHM was reflected in the values of three best practice football-for-HIV development organizations- Grassroot Soccer, Mathare Youth Sports Association and WhizzKids United. Given that researchers frequently use health models to create quantitative and qualitative evaluation measures, the presence of the COHM in the promotional materials seems to suggest its potential for use in building a uniform evaluation for football-for-development organizations. A standard procedure would provide additional credibility to programs, as well as enhance each program's ability to continue growing and establishing a sustainable presence in local communities worldwide. It is in addressing this evaluation problem that researchers can compare current program strengths, streamline the use of resources, and realize both local and international health development goals regarding the prevention of HIV.

\section{Recommendations for Future Research}

Since best practice football-for-HIV development organizations and larger global HIV prevention studies seem to reflect the value of the COHM tenets in HIV prevention, it is recommended that the next step for research, within standardizing an evaluation 
procedure for multiple organizations, would be to consult with Grassroot Soccer, Mathare Youth Sports Association and WhizzKids United to: 1) confirm/member check the accuracy of these conclusions and 2) work with key leaders to construct both a quantitative and qualitative evaluation procedure based off of the COHM tenets. Once created this standardized evaluation procedure could be implemented on-site, with multiple programs, to test the true utility of a COHM procedure in evaluating program effectiveness across cultures and programmatic efforts.

\section{Conclusions}

HIV/AIDS prevention has been the spotlight of international nonprofit work for the last decade (UNAIDS, 2010; World Health Organization, 2011b). Within this work there exists a specific focus on educating youth about HIV prevention through sportnamely football. While multiple organizations have found traction and community ownership with their programs, academic researchers and international partners are calling for a uniform evaluation to compare and track efforts across multiple organizations (Coalter \& Taylor, 2010c; Levermore, 2008). The COHM offers the utility to encompass the philosophy of sport-for-development, the recommendations for an evaluation procedure and reflects the promotional values of each organization, as exhibited through this content analysis. For these reasons, it seems rational to recommend the COHM be used to devise a pilot evaluation procedure, which may be able to bridge the borders of differences between the unique cultures where football-forHIV development programs are implemented. The end result would allow for the continued growth and dissemination of best practice information that would allow 
African communities to reach the ultimate goal of curtailing, and eventually defeating, this virus. 


\section{REFERENCES}

Africaid: WhizzKids United. (2009). Africaid's Whizzkids United annual report for the year ended 31 March, 2009. Durban, SA: Africaid.

Africaid: WhizzKids United. (2011). Annual report for the year ended 31 March 2011. Durban, SA: Africaid.

Alive and Kicking. (2011, June 4). What we do. Retrieved from: http://www.aliveandkicking.org/what-we-do/

Altheide, D.L. (1996). Qualitative media analysis. Thousand Oaks, CA: Sage Publications.

Andrews, C. (2010, August 23). Boosting health through football. Independent Nurse, 35.

Azzopardi, J. (2010). Not just for the kicks! football-for-development: Stakeholder perceptions of the WhizzKids United football program in Durban, South Africa. (Unpublished thesis). University of KwaZulu-Natal, Durban: South Africa.

Bailey, R. (2005). Evaluating the relationship between physical education, sport and social inclusion. Educational Review, 57(1), 71-90.

Banda, D., Lindsey, I., Jeanes, R., \& Kay, T. (2008). Partnerships involving sport-for development NGOs and the fight against HIV/AIDS. York, UK: York St. John University.

Beutler, I. (2008). Sport serving development and peace: Achieving the goal of the United Nations through sport. Sport in Society, 11, 359-369.

Botcheva, L., \& Huffman, L. (2004). Grassroot soccer foundation: HIV/AIDS education program: An intervention in Zimbabwe. Palo Alto: Children's Health Council.

Brady, M. \& Banu Khan, A. (2002). Letting girls play: The Mathare Youth Sports Association's football program for girls. New York: The Population Council.

Brunelli, A. \& Parisi, P. (2011). Sport as an instrument for people development and peace promotion. Theories and Applications the International Edition, 1(1) 1-10.

Burnett, C. \& Uys T. (2000). Sport development impact assessment: Towards a rationale and tool. South African Journal for Research in Sport, Physical Education and Recreation, 22(1), 27-40.

Campbell, C. (2001). Social capital and health: Contextualizing health promotion with local community networks. In S. Baron, J. Field, \& T. Schuller (Eds). Social capital: Critical perspectives (182-196). Oxford, UK: Oxford University. 
REFERENCES (continued)

Campbell, C., \& McPhail, C. (2002). Peer education, gender, and the development of critical consciousness: Participatory HIV prevention by South African youth. Social Science and Medicine, 55(2), 331-345.

Campbell, C., Foulis, C., Maimane, S. \& Sibiya, Z. (2005). The impact of social environments on the effectiveness of youth HIV prevention: A South African case study. AIDS Care, 17(4), 471-478.

Centers of Disease Control. (2011, June 4). About the CDC. Retrieved from: http://www.cdc.gov/about/

Coatler, F. (2008). Sport-in-development: A monitoring and evaluation manual. Scotland: University of Stirling.

Coalter, F. (2009). Sport-in-development: Accountability or development? In R. Levermore \& A. Beacom. Sport and International Development (55-75). UK: Palgrave Macmillan.

Coalter, F. (2010a). The politics of sport-for-development: Limited focus programmes and broad gauge problems? International Review for the Sociology of Sport, 45, 295-313.

Coalter, F. (2010b). Sport-for-development: Going beyond the boundary? Sport in Society, 13(9), 1374-1391.

Coalter, F., \& Taylor, J. (2010c). Sport-for-development impact study. University of Sterling, UK: Comic Relief.

Comic Relief. (2007). A literature review of sport and development. UK: Comic Relief. Retrieved from: http://www.comicrelief.com/

Delva, W. \& Temmermen, M. (2006). Determinants of the effectiveness of HIV prevention through sport. Retrieved from: http://www.toolkitsportdevelopment.org/

Denzin, N.K. \& Lincoln, Y.S. (2000). The discipline and practice of qualitative research. Thousand Oaks, CA: Sage Publications.

Dey, I. (1993). Qualitative data analysis. London, UK: Routledge.

Eley D. \& Kirk, D. (2002). Developing citizenship through sport: The impact of a sport based volunteer programme on young leaders. Sport, Education and Society, 7(2), 151-166. 
REFERENCES (continued)

Farrar, T., \& McGilvray, M. (2009). WhizzKids United brings football to life: A theoretical framework for youth HIV prevention in South Africa and throughout sub-Saharan Africa. Durban, SA: Africaid.

Farrar, T. (2011). Final report: WhizzKids United mixed gender football league. Durban, SA: Africaid.

FIFA: Federation Internationale de Football Association. (2010). Football for Hope. Zurich, Switzerland: FIFA.

FIFA: Federation Internationale de Football Association. (2011a, June 5). Football for hope: Program overview. Retrieved from: http://www.fifa.com/aboutfifa/worldwideprograms/footballforhope/index.html

FIFA: Federation Internationale de Football Association. (2011b, June 5). About FIFA. Retrieved from: http://www.fifa.com/aboutfifa/organisation/index.html

Giardina, M.D. (2010). One day, one goal? PUMA, corporate philanthropy and the cultural politics of brand "Africa." Sport in Society, 13(1), 130-142.

Glanz, K., Rimer, B. K., \& Viswanath, K. (2008). Health behavior and health education: Theory, research and practice $\left(4^{\text {th }} \mathrm{Ed}\right)$. San Francisco, CA: Jossey-Bass.

The Global Fund. (2011, May 31). History of the Global Fund. Retrieved from: http://www.theglobalfund.org/en/history/?lang=en

Goodman R.M., Speers, M.A., McLeroy, K., Fawcett, S., Kegler, M., Parker, E.,... Wallerstein, N. (1998). Identifying and defining the dimensions of community capacity to provide a basis for measurement. Health Education and Behavior, 25(3), 258-278.

Grassroot Soccer. (2006). Grassroot Soccer and diffusion of HIV knowledge: Do participants talk to others about HIV/AIDS? White River: Grassroot Soccer.

Grassroot Soccer. (2010). Grassroot Soccer 2010 annual report. Norwich: Grassroot Soccer.

Grassroot Soccer. (2011, June 2). History of Grassroot Soccer. Retrieved from: http://www.grassrootsoccer.org/who-we-are/history/

Grassroot Soccer. (2012, May 20). Grassroot Soccer Promotional Videos[Visual Files]. Retrieved from: http://www.youtube.com/user/grassrootsoccer

Green, C. (2008). Sport as an agent for social and personal change. In V. Girginov ( $3^{\text {rd }}$ Ed). Management of sports development (129-145). Oxford, UK: Elsevier. 
REFERENCES (continued)

Gregson, S., Terceira, N., Mushati, P., Nyamukapa, C., \& Campbell, C. (2004).

Community group participation: Can it help woman avoid HIV? An exploratory study of social capital and school education in Zimbabwe. Social Science and Medicine, 58(11), 2119-2132.

Griffths, J. (2005). HIV/AIDS intervention programs for youth in Africa: The role of Grassroot Soccer. (Unpublished thesis). Stanford University, Palo Alto.

Guion, L.A., Diehl, D.C., \& McDonald, D. (2011). Triangulation: Establishing the validity of qualitative studies. University of Florida IFAS Extension Service. Retrieved from: https://edis.ifas.ufl.edu/pdffiles/FY/FY39400.pdf

Holsti, O. R. (1969). Content analysis for the social sciences and humanities. Reading, MA: Addison-Wesley.

Houlihan, B., \& White, A. (2002). The politics of sports development: Development of sport or development through sport? London, UK: Routledge.

Human Rights Watch. (2005). Letting them fail: government neglect and the right to education for children affected by AIDS, 17(13). San Francisco, CA: Human Rights Watch.

Kay, T. (2009). Developing through sport: Evidencing sport impacts on young people. Sport in Society, 12, 1177-1191.

Kick4Life. (2012, February, 15). About Us. Retrieved from: http://kick4life.org/about-us/

Kreuger, M.W., Lezin, N.A, \& Koplan, A.N. (1997). Social capital: Evaluation implications for community health promotion. Atlanta, GA: World Health Organization.

Krippendorff, K. (1980). Content Analysis: An introduction to its methodology. Newbury Park, CA: Sage Publications.

Laub, C., Somera, D.M., Gowen, K.L., \& Diaz, R.M. (1999). Targeting “risky” gender ideologies: Constructing a community-driven, theory based HIV prevention intervention for youth. Health Education Behavior, 26, 185-199.

Lemke, W. (2012, March 28). Message of Support by Mr. Wilfred Lemke: Africaid's WhizzKids United. Geneva, Switzerland: United Nations Sport for Development and Peace.

Levermore, R. (2008). Sport: A new engine of development? Progress in Development Studies, 8(2), 183-190. 
REFERENCES (continued)

Levermore, R. (2011). Evaluating sport-for-development: Approaches and critical issues. Progress in Development Studies, 11(4), 339-353.

Lindsey, I. \& Banda, D. (2010). Sport and the fight against HIV/AIDS in Zambia: A “partnership approach?” Intl Review for the Sociology of Sport, 46(1), 90-107.

Locher, B.M. (2007). Developing a proposal to create a sport program for underserved youth in Cambodia: The creation of Sport Cambodia (Unpublished masters project). California Polytechnic State University, San Luis Obispo.

Lombard, M., Snyder-Dutch, J., \& Bracken, C.C. (2004). Practical resources for assessing and reporting intercoder reliability in content analysis research projects. Retrieved from: http://www.slis.indiana.edu/faculty/hrosenba/www/Research/ methods/lombard_reliability.pdf

Mathare Youth Sports Association. (2010). MYSA Strategic Plan 2010-2019. Mathare, Kenya: Mathare Youth Sports Association.

Mathare Youth Sports Association. (2011, September 4). Who we are: Our history. Retrieved from: http://www.mysakenya.org/Who-we-are/our-history.html

Mathare Youth Sports Association. (2012, May 20). Mathare Youth Sports Association Promotional Videos. [Visual Files]. Retrieved from: http://www.youtube.com/user/MYSAKenya?feature=mhum

Mayring, P. (2000). Qualitative Content Analysis. Qualitative Social Research, 1(2), Retrieved from:

http://www.qualitativeresearch.net/index.php/fqs/article/view/1089/2385Then

Miles, M. B. \& Huberman, M. A. (1984). Qualitative Data Analysis: A sourcebook of new methods. Beverly Hills, CA: Sage Publications.

Minkler, M. \& Cox, K. (1980). Creating critical consciousness in health: Applications of Friere's philosophy and methods to the health care setting. International Journal of Health Services, 10(2), 311-322.

Minkler, M., \& Wallerstein, N.B. (2002). Community Organization. In K.

Glanz, B.K. Reimer, \& K. Lewis ( $\left.3^{\text {rd }}\right)$. Health behavior and health education (279-311). San Francisco, CA: Jossey-Bass.

Mintzberg, H. (2006). Developing leaders? Developing countries? Development in Practice, 16(1), 4-14. 
REFERENCES (continued)

Misener, L. \& Mason, D.S. (2006). Creating community networks: Can sporting events offer meaningful sources of social capital? Managing Leisure, 11, 39-56.

Mwaanga, O. (2010). Sport for addressing HIV/AIDS: Explaining our convictions. LSA Newsletter, 85, 61-67.

Neuendorf, K. A. (2002). The content analysis guidebook. Thousand Oaks, CA: Sage Publications.

Nike CR Report. (2008). Let me play. Retrieved from: http://nikeresponsibility.com

Patton, M.Q. (2002). Qualitative research \& evaluation methods $\left(3^{\text {rd }}\right.$ Ed). Thousand Oaks, CA: Sage Publishers.

Piot, P., Bartos, M., Larson, H., Zewdie, D., \& Mane, P. (2008). Coming to terms with complexity: A call to action for HIV prevention. Geneva, Switzerland: UNAIDS.

President's Council on Physical Fitness and Sports. (2006). Sports and Character Development. Researcher Digest Series 7/1. Washington, DC: President's Council on Physical Fitness and Sports.

Rambaut, A., Posada, D., Crandall, K.A., \& Holmes, E.C. (2004). The causes and consequences of HIV evolution. Nature Reviews Genetics, 5, 52-61.

(RED). (2011a, May 15). The Latest Red Results. Retrieved from: http://www.joinred.com/red/\#home

(RED). (2011b, June 4). About (RED). Retrieved from: http://www.joinred.com/aboutred/the-red-manifesto/

Reis, H.T., \& Judd, C.M. (2000). Handbook of research methods in social and personality psychology. Cambridge, UK: Cambridge University Press.

Riffe, D., Lacy, S., \& Fico, F.G. (1998). Analyzing media messages: Using quantitative content analysis in research. New Jersey: Lawrence Erlbaum Associates Inc.

Right to Play. (2008). Harnessing the power of sport for development and peace: Recommendations to governments. Sport for Development and Peace Working Group. Toronto, Canada: Right to Play.

Saldana, J. (2009). The coding manual for qualitative researchers. Thousand Oaks: Sage Publications. 


\section{REFERENCES (continued)}

streetfootballworld. (2011, June 4). Development through football. Retrieved from: http://www.streetfootballworld.org/managecontent/development-throughfootball-1

Tengland, P. (2007). Empowerment: A goal or means for health promotion? Medicine, Health Care and Philosophy, 10, 197-207.

Tobisch, C. \& Preti, D. (2010). The role of football in HIV prevention in Africa. Brussels, Belgium: King Baudouin Foundation.

UNAIDS. (2001). Best practices in prevention collection. Geneva, Switzerland: UNAIDS.

UNAIDS. (2005). Best practices in expanding access to HIV treatment through community based organizations. Geneva, Switzerland: UNAIDS.

UNAIDS. (2010). Global report: UNAIDS report on the global AIDS epidemic. Geneva, Switzerland: UNAIDS.

United Nations. (2003). Sport as a means to promote education, health, development and peace. General Assembly Resolution 58/5. New York, NY: United Nations.

United Nations. (2006). International Year of Sport and Physical Education 2005-Final Report. Geneva, Switzerland: United Nations. Retrieved from: http://www.un.org/sport2005/a_year/IYSPE_Report_FINAL.pdf

United Nations. (2011, June 4). UN at a Glance. Retrieved from: http://www.un.org/en/aboutun/index.shtml

USAID. (2006). Grassroot Soccer: Resiliency pilot program evaluation Zambia \& South Africa. Washington, D.C.: Peacock-Villada, P.

Vienna Institute for International Dialogue. (2011, November 11). Football for development: Good practice guide on development initiatives through football. Retrieved from: http://footballfordevelopment.net

Wallerstein, N. \& Bernstein, E. (1988). Empowerment education: Friere's ideas adapted to health education. Health Education Quarterly, 15(4), 379-394.

Wa-Shiko, S.M. (2007). Mathare Youth Sports Association 2007 summer sabbatical final report. Nairobi, Kenya: University of Nairobi.

Weber, R.P. (1990). Basic content analysis $\left(2^{\text {nd }}\right.$ Ed). Newbury Park, CA: Sage Publications. 
REFERENCES (continued)

WhizzKids United. (2011, September 20). WhizzKids United History. Retrieved from http://www.whizzkidsunited.org/

WhizzKids United. (2012, May 20). WhizzKids United Promotional Videos. [Visual files]. Retrieved from: http://www.youtube.com/whizzkidsunited

Woodcock, A. (2007). Appendix 6: Report on MYSA, Nairobi, Kenya: Sport as a catalyst for social change. London, UK: Laureus Sport for Good Foundation.

World Health Organization. (2006). Towards universal access by 2010: How WHO is working with countries to scale-up HIV prevention, treatment, care and support. Geneva, Switzerland: World Health Organization.

World Health Organization Department of Health Statistics. (2011a). World Health Statistics 2011. Geneva, Switzerland: World Health Organization.

World Health Organization. (2011b). Draft: WHO HIV Strategy 2011-2015. Geneva, Switzerland: World Health Organization.

World Health Organization. (2012, September 9). About WHO. Retrieved from: http://www.who.int/about/en/ 
Appendix A

Process for Developing a Content Analysis 
Appendix A: Step-by-Step Process for Developing a Content Analysis

(Neuendorf, 2002)

1) Define unit of analysis

2) Establish coding categories

3) Pilot or pretest coding categories on sample documents

4) Assess reliability of the coding

5) Revise coding categories if necessary and return to step 3

6) Draw the sample of documents

7) Code all units of analysis

8) Assess achieved reliability of the coding, and

9) Tabulate categories and cross-tabulate where appropriate (p.29) 
Appendix B

Pilot Codebook 


\begin{tabular}{|c|c|c|c|c|c|}
\hline Category & Brief Definition & Full Definition & Inclusion & Exclusion & Example \\
\hline $\begin{array}{l}\text { Sport/Football- for- } \\
\text { Development } \\
\text { General }\end{array}$ & & $\begin{array}{c}\text { Utilization of sport } \\
\text { (football) as a tool to foster } \\
\text { personal and social } \\
\text { improvements of those } \\
\text { people and communities } \\
\text { most in need of } \\
\text { development }\end{array}$ & $\begin{array}{l}\text { This code should be used when } \\
\text { general benefits of program are } \\
\text { described or overarching } \\
\text { mission's statements covering } \\
\text { multiple coding categories are } \\
\text { made. }\end{array}$ & $\begin{array}{l}\text { The broad Sport/football for } \\
\text { development code should } \\
\text { only be used to code items } \\
\text { that are SFD related, but do } \\
\text { not specifically address the } \\
\text { subcategories }\end{array}$ & $\begin{array}{l}\text { "Embracing a vision of } \\
\text { using sports to effect } \\
\text { positive social change to } \\
\text { underprivileged } \\
\text { communities" }\end{array}$ \\
\hline $\begin{array}{l}\text { 1. Unification of } \\
\text { Community }\end{array}$ & $\begin{array}{l}\text { Key words: } \\
\text { Football unites the } \\
\text { community }\end{array}$ & $\begin{array}{l}\text {-Sport's potential to bring } \\
\text { individuals from different } \\
\text { parts of the community } \\
\text { together as one. }\end{array}$ & $\begin{array}{l}\text { Should code as unification if it } \\
\text { speaks about gathering } \\
\text { community }\end{array}$ & $\begin{array}{l}\text { This code is used specifically } \\
\text { only for the moments of } \\
\text { describing brings community } \\
\text { together }\end{array}$ & $\begin{array}{l}\text { "In most places, simply } \\
\text { arriving at a field with a } \\
\text { soccer ball will win you } \\
\text { instant friendships and } \\
\text { immediate access into } \\
\text { local community." }\end{array}$ \\
\hline 2. Youth & $\begin{array}{l}\text { Key words: } \\
\text { Football is well suited } \\
\text { to attract youth's } \\
\text { interest }\end{array}$ & $\begin{array}{l}\text {-Due to the ease of } \\
\text { administration and } \\
\text { popularity of the sport, } \\
\text { football engages youth } \\
\text { more than other sports }\end{array}$ & $\begin{array}{l}\text { This code should only be used } \\
\text { to describe instances that } \\
\text { football is emphasized as a } \\
\text { powerful tool for attracting } \\
\text { YOUTH. }\end{array}$ & $\begin{array}{l}\text { This code should not be used } \\
\text { to describe football's ability } \\
\text { to engage or unify any other } \\
\text { community aside from } \\
\text { youth. }\end{array}$ & $\begin{array}{l}\text { "Every football team is a } \\
\text { "mobilized" youth group." }\end{array}$ \\
\hline 3. Gender Equity & $\begin{array}{c}\text { Key words: } \\
\text { Research has shown } \\
\text { SFD to be useful to } \\
\text { gender equity purposes }\end{array}$ & $\begin{array}{l}\text { The active use of sport to } \\
\text { engage females to break } \\
\text { barriers of stigma and } \\
\text { discrimination based upon } \\
\text { gender roles }\end{array}$ & $\begin{array}{l}\text { This code should be used to } \\
\text { code pieces of information that } \\
\text { emphasize why sport is well } \\
\text { suited for addressing gender } \\
\text { disparities }\end{array}$ & $\begin{array}{l}\text { This code should NOT be } \\
\text { used to describe the specific } \\
\text { process of HOW sport is } \\
\text { used (i.e. through } \\
\text { empowering girls etc.) }\end{array}$ & $\begin{array}{l}\text { "Girls should have the } \\
\text { same access to public } \\
\text { space and social visibility } \\
\text { as the boys in a } \\
\text { community." }\end{array}$ \\
\hline Empowerment & $\begin{array}{c}\text { Key words: } \\
\text {-Break expectations and } \\
\text { stigma }\end{array}$ & $\begin{array}{l}\text { Enabling process through } \\
\text { which individuals or } \\
\text { communities take control } \\
\text { over life or environment } \\
\text {-Multilayered- individual, } \\
\text { community and } \\
\text { organization }\end{array}$ & $\begin{array}{l}\text { Empowerment items should } \\
\text { generally be coded if the } \\
\text { passage makes reference to } \\
\text { empowerment at multiple } \\
\text { levels (com, indiv etc.) OR if it } \\
\text { means empowerment } \\
\text { associated with any other key } \\
\text { words not found in the } \\
\text { subcategories }\end{array}$ & $\begin{array}{l}\text { Do NOT use the general } \\
\text { empowerment code to code } \\
\text { data that refers to one of the } \\
\text { four subcategories }\end{array}$ & $\begin{array}{l}\text { "...worked directly with } \\
\text { programs designed to } \\
\text { empower youth and make } \\
\text { meaningful changes in the } \\
\text { lives of children and } \\
\text { communities." }\end{array}$ \\
\hline $\begin{array}{l}\text { 1.Competence/ } \\
\text { Self-Efficacy }\end{array}$ & $\begin{array}{c}\text { Key words: } \\
\text {-self-esteem } \\
\text {-self-worth } \\
\text {-self-confidence }\end{array}$ & $\begin{array}{l}\text { Specific measures that have } \\
\text { been taken to increase an } \\
\text { individual competency in } \\
\text { political and social areas } \\
\text { and their belief in their } \\
\text { potential for success }\end{array}$ & $\begin{array}{l}\text { Use this category to code any } \\
\text { passages that refer to } \\
\text { empowerment that focuses on } \\
\text { building self-concept }\end{array}$ & $\begin{array}{c}\text { Do NOT use this coding } \\
\text { category to code passages } \\
\text { that refer to competency/self } \\
\text { efficacy as it relates to actual } \\
\text { knowledge } \\
\text { building/achievement }\end{array}$ & $\begin{array}{l}\text { "The goal is to empower } \\
\text { youth with critical life } \\
\text { skills including self- } \\
\text { esteem, teamwork, } \\
\text { discipline and decision- } \\
\text { making." }\end{array}$ \\
\hline
\end{tabular}




\begin{tabular}{|c|c|c|c|c|c|}
\hline 2.Hope/Optimism & $\begin{array}{l}\text { Key words: } \\
\text {-enable hope } \\
\text {-optimism } \\
\text {-resilience }\end{array}$ & $\begin{array}{l}\text { Empowerment that focuses } \\
\text { on reframing participant's } \\
\text { view of the HIV problem in } \\
\text { a positive, hopeful light. }\end{array}$ & $\begin{array}{l}\text { This code should be used only } \\
\text { to describe the psychological } \\
\text { effects of positive thinking and } \\
\text { empowerment. }\end{array}$ & & $\begin{array}{l}\text { "It helps them take small } \\
\text { steps to achieve their goals } \\
\text { and are resilient when } \\
\text { faced with challenges... } \\
\text { believing they can protect } \\
\text { themselves and others } \\
\text { from HIV." }\end{array}$ \\
\hline $\begin{array}{l}\text { 3.Knowledge/ } \\
\text { Achievement }\end{array}$ & $\begin{array}{l}\text { Key words: } \\
\text {-educate } \\
\text {-determination } \\
\text {-achievement }\end{array}$ & $\begin{array}{l}\text { This element of } \\
\text { empowerment specifically } \\
\text { refers to all measures meant } \\
\text { to empower individuals } \\
\text { through providing access to } \\
\text { education and knowledge } \\
\text { that can increase their } \\
\text { capacity }\end{array}$ & $\begin{array}{l}\text { Use this code to code any } \\
\text { passage that refers to education, } \\
\text { or increasing an individual's } \\
\text { capability through any sort of } \\
\text { formal education. }\end{array}$ & $\begin{array}{l}\text { Do NOT use this code for } \\
\text { the passage if the passage is } \\
\text { talking about the feelings of } \\
\text { self-efficacy and confidence } \\
\text { that can come from } \\
\text { education. }\end{array}$ & $\begin{array}{l}\text { "There is a need to invest } \\
\text { considerable resources and } \\
\text { efforts in raising the } \\
\text { professional capacity of } \\
\text { MYSA staff and } \\
\text { volunteers." }\end{array}$ \\
\hline $\begin{array}{l}\text { 4. Mastery of Self/ } \\
\text { Responsibility }\end{array}$ & $\begin{array}{l}\text { Key words: } \\
\text {-mastery of self/life } \\
\text {-responsibility for role } \\
\text {-legitimize place in } \\
\text { society }\end{array}$ & $\begin{array}{l}\text { Growing in the capacity } \\
\text { and confidence to accept } \\
\text { social role in making } \\
\text { change in community. } \\
\text { Finding ways to change } \\
\text { society within the confines } \\
\text { of current infrastructures }\end{array}$ & $\begin{array}{l}\text { This code has more to do with } \\
\text { breaking social norms and } \\
\text { acknowledging that the } \\
\text { individual has a meaningful } \\
\text { place in society, outside the } \\
\text { social norms. Primarily used } \\
\text { for more political or social } \\
\text { empowerment }\end{array}$ & $\begin{array}{l}\text { Do NOT use this code for } \\
\text { passage if is speaking about } \\
\text { building knowledge or } \\
\text { achievement, this } \\
\text { empowerment has more to } \\
\text { do with the political and } \\
\text { social empowerment }\end{array}$ & $\begin{array}{l}\text { "By working within this } \\
\text { existing structure and by } \\
\text { training role models- pro } \\
\text { players, coaches and youth } \\
\text { players themselves to get } \\
\text { the message out about } \\
\text { HIV." }\end{array}$ \\
\hline $\begin{array}{c}\text { Critical } \\
\text { Consciousness }\end{array}$ & & $\begin{array}{l}\text { Social analysis of } \\
\text { conditions and peoples' } \\
\text { roles in changing these } \\
\text { conditions }\end{array}$ & $\begin{array}{l}\text { This general code should be } \\
\text { used when critical } \\
\text { consciousness appears not } \\
\text { within one of the below } \\
\text { subcategories }\end{array}$ & $\begin{array}{l}\text { Do NOT use the general } \\
\text { code if the passage can be } \\
\text { housed under one of the } \\
\text { subcategories }\end{array}$ & $\begin{array}{c}\text { "Conversation takes place } \\
\text { at interventions. } \\
\text { Participants are } \\
\text { encouraged to share their } \\
\text { person, real stories. } \\
\text { Different ideas from } \\
\text { different people can } \\
\text { change lives." }\end{array}$ \\
\hline 1. Awareness & $\begin{array}{l}\text { Key words: } \\
\text {-awareness based on } \\
\text { reflection } \\
\text {-exposure } \\
\text { recognition/realization }\end{array}$ & $\begin{array}{l}\text { Awareness critical } \\
\text { consciousness is based } \\
\text { upon awareness of the } \\
\text { issues. This includes } \\
\text { exposing youth to the issues } \\
\text { to initiate discussions. }\end{array}$ & $\begin{array}{c}\text { Use this code for coding } \\
\text { passages that speak about } \\
\text { engaging in discussion to raise } \\
\text { awareness about community } \\
\text { issues }\end{array}$ & $\begin{array}{l}\text { This code is only to be used } \\
\text { for initiating discussion } \\
\text { about community issues }\end{array}$ & $\begin{array}{l}\text { "Working with the } \\
\text { youth...these skills of } \\
\text { being aware and focused } \\
\text { helps me a lot with } \\
\text { identifying people who } \\
\text { have problems or who may } \\
\text { need my help, without } \\
\text { asking them if they do." }\end{array}$ \\
\hline
\end{tabular}




\begin{tabular}{|c|c|c|c|c|c|}
\hline $\begin{array}{l}\text { 2. Political/Social } \\
\text { Reality }\end{array}$ & $\begin{array}{l}\text { Key words: } \\
\text {-informed } \\
\text {-sensitized }\end{array}$ & $\begin{array}{l}\text { Critical consciousness } \\
\text { particularly focusing on the } \\
\text { individual's recognition of } \\
\text { their role within the } \\
\text { political and social reality } \\
\text { of the community issue }\end{array}$ & $\begin{array}{l}\text { This code should be used for } \\
\text { passages that specifically focus } \\
\text { on the political or social norm } \\
\text { situations that contribute to } \\
\text { community issues. }\end{array}$ & & $\begin{array}{l}\text { "While most ministries } \\
\text { have policies that } \\
\text { acknowledge the equal } \\
\text { rights of boys and girls, in } \\
\text { practice relatively few of } \\
\text { these policies are in } \\
\text { action." }\end{array}$ \\
\hline $\begin{array}{l}\text { 3. Identifying } \\
\text { Practical Solutions }\end{array}$ & $\begin{array}{l}\text { Key words: } \\
\text {-connects cause to } \\
\text { community action } \\
\text {-contribute }\end{array}$ & $\begin{array}{l}\text { Critical consciousness in } \\
\text { the process of not just } \\
\text { discussing but identifying } \\
\text { practical, feasible solutions }\end{array}$ & $\begin{array}{l}\text { This code should be used for } \\
\text { passages that discuss actual } \\
\text { practical solutions that are } \\
\text { discussed. }\end{array}$ & $\begin{array}{l}\text { This code should NOT be } \\
\text { used just for a discussion of } \\
\text { a problem, but for the } \\
\text { discussion of solutions. }\end{array}$ & $\begin{array}{l}\text { "Girls participation can } \\
\text { begin change to } \\
\text { community norms about } \\
\text { their roles and capacities." }\end{array}$ \\
\hline Issue Selection & $\begin{array}{c}\text { Key words: } \\
\text { unifying process for } \\
\text { community action } \\
\text {-winnable, specific } \\
\text { goals } \\
\text {-tangible and clearly } \\
\text { articulated }\end{array}$ & $\begin{array}{l}\text { Differentiation between } \\
\text { problems (troubling to } \\
\text { community) vs. issues they } \\
\text { feel strongly upon acting on } \\
\text {-unifying process to build } \\
\text { community strength }\end{array}$ & $\begin{array}{l}\text { The general issue selection } \\
\text { code should be used, when an } \\
\text { issue selection passage does not } \\
\text { fit into any of the below } \\
\text { categories }\end{array}$ & & $\begin{array}{l}\text { "It is recommended that } \\
\text { interventions, including } \\
\text { HIV communication } \\
\text { programs that take into } \\
\text { account epidemiological } \\
\text { and socio-cultural factors } \\
\text { be developed and } \\
\text { implemented at a } \\
\text { provincial level." }\end{array}$ \\
\hline 1. Process of Selecting & & $\begin{array}{l}\text {-winnable and specific } \\
\text { goals } \\
\text {-community should be } \\
\text { bought into and supportive } \\
\text { of the goals/issues selected }\end{array}$ & $\begin{array}{l}\text { This code should be used to } \\
\text { describe any processes that } \\
\text { occur for a community to meet } \\
\text { and discuss the issues most } \\
\text { relevant to the community. }\end{array}$ & $\begin{array}{l}\text { Do NOT use this code when } \\
\text { a passage is describing } \\
\text { outlining an actual strategic } \\
\text { plan for addressing an issue. } \\
\text { This code is only meant for } \\
\text { the process of discussing and } \\
\text { decided upon an issue, not } \\
\text { deciding how to act on the } \\
\text { issue }\end{array}$ & $\begin{array}{l}\text { "The program allows kids } \\
\text { a forum to come together } \\
\text { and rethink unhealthy } \\
\text { social norms and } \\
\text { stereotypes... and do } \\
\text { something to change that." }\end{array}$ \\
\hline $\begin{array}{l}\text { 2. HIV Specific- } \\
\text { Research }\end{array}$ & $\begin{array}{l}\text { Key words: } \\
\text {-safety } \\
\text {-supportive } \\
\text { - }\end{array}$ & $\begin{array}{l}\text {-issue selection that is } \\
\text { based on HIV specific } \\
\text { research or proven methods } \\
\text { for prevention including } \\
\text { content international } \\
\text { organizations endorse }\end{array}$ & $\begin{array}{l}\text { This code should be used for } \\
\text { passages that describe engaging } \\
\text { in certain issue selection based } \\
\text { upon research into best } \\
\text { methods/most important } \\
\text { problems of HIV }\end{array}$ & $\begin{array}{l}\text { Do NOT use this code to } \\
\text { describe community selected } \\
\text { issued, this should reflect } \\
\text { organization selected issues } \\
\text { based upon HIV academic } \\
\text { literature recommendations }\end{array}$ & $\begin{array}{l}\text { "It has been shown that at } \\
\text { risk adolescent boys and } \\
\text { girls need a physically safe } \\
\text { and supportive } \\
\text { environment to engage in } \\
\text { healthy activity." }\end{array}$ \\
\hline $\begin{array}{l}\text { 3.HIV Specific- } \\
\text { Community Desires }\end{array}$ & & $\begin{array}{c}\text { tangible, agreed upon } \\
\text { encompassing values and } \\
\text { concerns } \\
\text {-may include community } \\
\text { needs assessment }\end{array}$ & $\begin{array}{l}\text { This code should be used for } \\
\text { passages describing engaging } \\
\text { in issue selection based on the } \\
\text { issues the community (not the } \\
\text { organization) decides are }\end{array}$ & $\begin{array}{l}\text { Do NOT use this code to } \\
\text { describe organization actions } \\
\text { that reflect the organizations } \\
\text { priorities but not the } \\
\text { community's. }\end{array}$ & $\begin{array}{l}\text { "GRS engaged in a needs } \\
\text { assessment of the } \\
\text { community before } \\
\text { planning and } \\
\text { implementing the new }\end{array}$ \\
\hline
\end{tabular}




\begin{tabular}{|c|c|c|c|c|c|}
\hline & & & important. & & phase of the program." \\
\hline 4. Strategic Goals & $\begin{array}{c}\text { Key words: } \\
\text {-plan for evaluation and } \\
\text { monitoring } \\
\text {-actions clearly stated }\end{array}$ & $\begin{array}{l}\text {-comprehensive strategy } \\
\text { goal monitoring } \\
\text {-should be clear enough for } \\
\text { any member of the } \\
\text { community to explain to } \\
\text { another the goal and plan } \\
\text { for addressing the issue }\end{array}$ & $\begin{array}{l}\text { This code is meant for passages } \\
\text { that describe the process of a } \\
\text { strategic plan for addressing the } \\
\text { issue selected }\end{array}$ & $\begin{array}{l}\text { Do NOT use this code for } \\
\text { the decisional process of } \\
\text { choosing an issue, it should } \\
\text { only be used for describing } \\
\text { the planning of an action } \\
\text { strategy }\end{array}$ & $\begin{array}{l}\text { "MYSA cleared a business } \\
\text { plan for growth of } \\
\text { renewing organizational } \\
\text { and governance structures } \\
\text { and clearly articulating to } \\
\text { the outside world what } \\
\text { MYSA is about and how it } \\
\text { intends to grow." }\end{array}$ \\
\hline Community Capacity & & $\begin{array}{l}\text { Characteristics of the } \\
\text { community that allow the } \\
\text { ability to identify, mobilize } \\
\text { and address social and } \\
\text { health concerns }\end{array}$ & $\begin{array}{l}\text { This code should be used for } \\
\text { any passage that speaks about } \\
\text { community capacity in a more } \\
\text { generic way and/or does not fit } \\
\text { within any of the community } \\
\text { capacity. }\end{array}$ & $\begin{array}{l}\text { Do NOT use this code for } \\
\text { anything that falls within one } \\
\text { of the below subcategories }\end{array}$ & $\begin{array}{l}\text { "The WhizzKids United } \\
\text { Health Academy is our } \\
\text { adolescent-focused health } \\
\text { centre that offers the best } \\
\text { in HIV counseling and } \\
\text { treatment. It also provides } \\
\text { great after school } \\
\text { resources for youth such as } \\
\text { activity-centered clubs and } \\
\text { academic support groups." }\end{array}$ \\
\hline 1. Access & & $\begin{array}{l}\text { Part of a community's } \\
\text { capacity is its access to } \\
\text { resources that could be used } \\
\text { to address issues }\end{array}$ & $\begin{array}{l}\text { This code should be used for } \\
\text { any passage that speaks about } \\
\text { current level of access or ways } \\
\text { to gain additional access to } \\
\text { resources (note: resources can } \\
\text { be material or human) }\end{array}$ & $\begin{array}{l}\text { Do NOT use this code that } \\
\text { addresses the capacity of the } \\
\text { community to actually USE } \\
\text { resources at their disposal, } \\
\text { this only houses discussion } \\
\text { of accessing resources. }\end{array}$ & $\begin{array}{l}\text { "Outside the classroom, } \\
\text { "Team Talk" Peer } \\
\text { Education also serves as } \\
\text { an approachable front-line } \\
\text { resource of help for } \\
\text { troubled youth who might } \\
\text { be too intimidated to go to } \\
\text { an authority figure. Peer } \\
\text { leaders have HIV } \\
\text { education and can help } \\
\text { peers can access to HIV } \\
\text { clinics." }\end{array}$ \\
\hline 2. Mobilization & $\begin{array}{l}\text {-Community leaders } \\
\text { willing to take } \\
\text { ownership of leading } \\
\text { programs }\end{array}$ & $\begin{array}{l}\text { The community's capacity } \\
\text { to move resources in a } \\
\text { direction that allows them } \\
\text { to actually address the } \\
\text { issue. The movement of } \\
\text { resources }\end{array}$ & $\begin{array}{l}\text { This code should be used for } \\
\text { any passage that speaks about } \\
\text { actually utilizing the resources } \\
\text { to directly address the problem. }\end{array}$ & $\begin{array}{l}\text { Do NOT use this code for } \\
\text { anything other than } \\
\text { discussion of targeting } \\
\text { resources on action toward } \\
\text { the problem }\end{array}$ & $\begin{array}{l}\text { "It creates a sense of } \\
\text { solidarity amongst youth } \\
\text { that they are working } \\
\text { together in the mission of } \\
\text { living healthy and HIV- } \\
\text { free." }\end{array}$ \\
\hline 3. Shared Expertise & & $\begin{array}{c}\text { Capacity of the community } \\
\text { to interact with experts both } \\
\text { locally and from } \\
\text { international locations to }\end{array}$ & $\begin{array}{l}\text { This code should be used for } \\
\text { passages that talk about the } \\
\text { collective expertise of the } \\
\text { community or individuals effort }\end{array}$ & $\begin{array}{l}\text { Do NOT use this to talk } \\
\text { about knowledge } \\
\text { development (this skill } \\
\text { development should fall }\end{array}$ & $\begin{array}{l}\text { "Teachers are very } \\
\text { satisfied with the program } \\
\text { and would like to see more } \\
\text { ways to sustain the results, }\end{array}$ \\
\hline
\end{tabular}




\begin{tabular}{|c|c|c|c|c|c|}
\hline & & $\begin{array}{l}\text { continue expanding } \\
\text { resources and ideas for } \\
\text { addressing the issues }\end{array}$ & $\begin{array}{l}\text { to increase the expertise of the } \\
\text { locals. }\end{array}$ & $\begin{array}{l}\text { under empowerment } \\
\text { UNLESS it is for the specific } \\
\text { purpose of expanding the } \\
\text { community's capacity, in } \\
\text { which case it should be } \\
\text { coded as below }\end{array}$ & $\begin{array}{l}\text { include helping them be } \\
\text { more involved in the } \\
\text { educational process." }\end{array}$ \\
\hline $\begin{array}{l}\text { 4. Collective Skills \& } \\
\text { Education }\end{array}$ & & $\begin{array}{l}\text { The collective skills and } \\
\text { education of the } \\
\text { community. }\end{array}$ & $\begin{array}{l}\text { This code should be used for } \\
\text { passages that analyze the } \\
\text { current levels of } \\
\text { skill/knowledge in the } \\
\text { community and/or plan for } \\
\text { increasing that capacity }\end{array}$ & $\begin{array}{l}\text { This skill development does } \\
\text { not fall under empowering } \\
\text { education, as this is specific } \\
\text { training for local community } \\
\text { members to continue to the } \\
\text { work toward resolving the } \\
\text { issue }\end{array}$ & $\begin{array}{l}\text { "A limiting factor in } \\
\text { growth will be staff that } \\
\text { lack the core skills and } \\
\text { capacities necessary to } \\
\text { take programs to the next } \\
\text { level." }\end{array}$ \\
\hline Category & Brief Definition & Full Definition & Inclusion & Exclusion & Example \\
\hline Social Capital & & $\begin{array}{c}\text {-coordination and } \\
\text { cooperation for mutual } \\
\text { benefit } \\
\text {-horizontal relationship of } \\
\text { power } \\
\text {-relationships of equity }\end{array}$ & $\begin{array}{l}\text { This code should be used for } \\
\text { any general concept of social } \\
\text { capital or the lack of ability to } \\
\text { use one of the subcategories. }\end{array}$ & $\begin{array}{l}\text { Do NOT use this code for } \\
\text { any passage that could be } \\
\text { under one of the } \\
\text { subcategories. }\end{array}$ & $\begin{array}{l}\text { "You do something, I do } \\
\text { something; you do } \\
\text { nothing, I do nothing. } \\
\text { Youth seem to interact } \\
\text { with this concept with } \\
\text { great ease and appreciated } \\
\text { the meaning and } \\
\text { responsibility behind it." }\end{array}$ \\
\hline $\begin{array}{l}\text { 1. Trust } \& \text { Respect } \\
\text { Relations }\end{array}$ & $\begin{array}{l}\text { Key words: } \\
\text {-trust } \\
\text {-respect } \\
\text {-reciprocity }\end{array}$ & $\begin{array}{l}\text { Social capital related to } \\
\text { taking measures to build } \\
\text { trust and respect between } \\
\text { community members }\end{array}$ & $\begin{array}{l}\text { This code should be used for } \\
\text { any passages that are speaking } \\
\text { of processes in place to build } \\
\text { trust, respect and unity in the } \\
\text { community }\end{array}$ & $\begin{array}{l}\text { Do NOT use this code to } \\
\text { describe the reciprocal } \\
\text { relationships that come from } \\
\text { this trust and respect. }\end{array}$ & $\begin{array}{l}\text { "Half of all elected MYSA } \\
\text { leaders are girls, including } \\
\text { the elected chair of the } \\
\text { overall MYSA Executive } \\
\text { Council" }\end{array}$ \\
\hline 2. Civic Engagement & $\begin{array}{c}\text { Key words: } \\
\text {-stakeholders } \\
\text {-investment } \\
\text {-articulation of values }\end{array}$ & $\begin{array}{l}\text { Social capital as it is } \\
\text { actually measureable with } \\
\text { the community's } \\
\text { involvement in action. }\end{array}$ & $\begin{array}{l}\text { This code should be used for } \\
\text { any passages that speak about } \\
\text { actual community involvement } \\
\text { in addressing the issue }\end{array}$ & & $\begin{array}{l}\text { "Our boys and girls play } \\
\text { football matches, but also } \\
\text { carry out a wide range of } \\
\text { environmental cleanup and } \\
\text { other self-help community } \\
\text { service activities." }\end{array}$ \\
\hline $\begin{array}{l}\text { 3. Helping Self \& } \\
\text { Community }\end{array}$ & $\begin{array}{l}\text { Key words: } \\
\text {-exchange }\end{array}$ & $\begin{array}{c}\text { Social capital as it } \\
\text { emphasizes the mutual } \\
\text { benefit of helping self and } \\
\text { community }\end{array}$ & $\begin{array}{l}\text { This code should be used for } \\
\text { any passages that speak about } \\
\text { reciprocal relationships or } \\
\text { community stakeholders. }\end{array}$ & $\begin{array}{l}\text { Do NOT use this code to } \\
\text { describe the reciprocal } \\
\text { relationship that should exist } \\
\text { between an org and } \\
\text { community and/or outside } \\
\text { partners. This code is talking } \\
\text { about these relationships in } \\
\text { the community. }\end{array}$ & $\begin{array}{l}\text { "The main goal and motto } \\
\text { of MYSA is to "give youth } \\
\text { a sporting chance" to help } \\
\text { themselves and their } \\
\text { community" }\end{array}$ \\
\hline
\end{tabular}




\begin{tabular}{|c|c|c|c|c|c|}
\hline $\begin{array}{l}\text { Participation \& } \\
\text { Relevance }\end{array}$ & $\begin{array}{c}\text { Key words: } \\
\text {-shared power and } \\
\text { execution of issue } \\
\text { selection and } \\
\text { community capacity }\end{array}$ & $\begin{array}{c}\text { Creates an agenda based } \\
\text { upon felt needs, shared } \\
\text { power and awareness of } \\
\text { resources } \\
\text {-This includes helping to } \\
\text { transfer leadership to local } \\
\text { leaders as well as } \\
\text { decentralization of foreign } \\
\text { leadership (move into a } \\
\text { partner role) }\end{array}$ & $\begin{array}{l}\text { This code should be used to } \\
\text { code any passages that talk } \\
\text { about the concepts of building } \\
\text { greater community } \\
\text { participation and or altering the } \\
\text { program to make it more } \\
\text { relevant. }\end{array}$ & $\begin{array}{l}\text { Do NOT use this general } \\
\text { code to describe any of the } \\
\text { subcategories. }\end{array}$ & $\begin{array}{l}\text { "The WhizzKids United } \\
\text { Health Academy provides } \\
\text { a holistic range of services } \\
\text { free of charge in an } \\
\text { adolescent-friendly, non- } \\
\text { judgmental environment, } \\
\text { and it gives kids a venue } \\
\text { of which they can take } \\
\text { ownership and see it as } \\
\text { "their place." }\end{array}$ \\
\hline 1. Where People Are & $\begin{array}{c}\text {-start where the people } \\
\text { are } \\
\text {-all-engaging }\end{array}$ & $\begin{array}{l}\text { This refers to the area of } \\
\text { relevance that ensures the } \\
\text { actual implementation of } \\
\text { efforts to address issues } \\
\text { reflects the current } \\
\text { capacities and desires of the } \\
\text { community }\end{array}$ & $\begin{array}{l}\text { This code should be used for } \\
\text { passages that talk about } \\
\text { relevance in particular } \\
\text { addressing the current state of } \\
\text { community affairs }\end{array}$ & $\begin{array}{c}\text { This code may overlap with } \\
\text { other codes... }\end{array}$ & $\begin{array}{l}\text { "MYSA prides itself in } \\
\text { being an organization for } \\
\text { youth, run by the youth } \\
\text { themselves." }\end{array}$ \\
\hline $\begin{array}{l}\text { 2. Evaluation/ } \\
\text { Progression }\end{array}$ & $\begin{array}{l}\text {-impact assessments } \\
\text {-evaluation/community } \\
\text { feedback in process }\end{array}$ & $\begin{array}{l}\text { Addressing the continued } \\
\text { relevance and growth of the } \\
\text { program through valuing } \\
\text { evaluation and hearing } \\
\text { community feedback. }\end{array}$ & $\begin{array}{l}\text { This should be used for any } \\
\text { passages that reflect any } \\
\text { evaluation measures } \\
\text { (describing how and when) as } \\
\text { well as mention of continued } \\
\text { growth plans }\end{array}$ & $\begin{array}{l}\text { Do NOT use this code to } \\
\text { describe the content of an } \\
\text { evaluation. }\end{array}$ & $\begin{array}{l}\text { "GRS is at the cutting } \\
\text { edge of curriculum } \\
\text { development. With the } \\
\text { understanding that it is } \\
\text { never static- they are } \\
\text { always incorporating } \\
\text { community feedback, both } \\
\text { formal and informal to } \\
\text { make it better." }\end{array}$ \\
\hline $\begin{array}{l}\text { 3. Culturally } \\
\text { Appropriate } \\
\text { Implementation }\end{array}$ & $\begin{array}{l}\text {-actions are culturally } \\
\text { appropriate } \\
\text {-integration }\end{array}$ & $\begin{array}{l}\text { Culturally appropriate is a } \\
\text { combination of appropriate } \\
\text { evaluation measures and } \\
\text { focusing on altering } \\
\text { programs as need be due to } \\
\text { response }\end{array}$ & $\begin{array}{l}\text { This code should be used to } \\
\text { describe the content and } \\
\text { method of evaluations as well } \\
\text { as ways to keep accountable for } \\
\text { the goals set for program } \\
\text { implementation }\end{array}$ & $\begin{array}{l}\text { Do NOT use this code for } \\
\text { more general discussion of } \\
\text { the evaluation. }\end{array}$ & $\begin{array}{l}\text { "Most are top players...the } \\
\text { best players are the best } \\
\text { way to reach many other } \\
\text { youth with crucial } \\
\text { information." }\end{array}$ \\
\hline $\begin{array}{l}\text { 4. Owned and } \\
\text { Managed By } \\
\text { Community }\end{array}$ & $\begin{array}{l}\text {-community of equals } \\
\text {-decentralization } \\
\text {-community determines } \\
\text { direction and input } \\
\text { - local leadership } \\
\text { executed (ownership) }\end{array}$ & $\begin{array}{l}\text { Organizations should work } \\
\text { toward as much local } \\
\text { leadership as possible, } \\
\text { including plans of } \\
\text { decentralizing the use of } \\
\text { outsiders }\end{array}$ & $\begin{array}{l}\text { This code should be used to } \\
\text { describe plans that allow } \\
\text { transferring more power and } \\
\text { ownership over to the } \\
\text { community }\end{array}$ & & $\begin{array}{l}\text { "Hundreds of MYSA } \\
\text { youth leaders between 13- } \\
20 \text { years old have been } \\
\text { training on AIDS } \\
\text { prevention and peer } \\
\text { counseling." }\end{array}$ \\
\hline $\begin{array}{l}\text { Partnership \& } \\
\text { Sustainability }\end{array}$ & $\begin{array}{c}\text {-investment } \\
\text {-consultation } \\
\text {-expertise }\end{array}$ & $\begin{array}{l}\text { Partnership is not } \\
\text { necessarily focused on } \\
\text { reciprocity of benefits }\end{array}$ & $\begin{array}{l}\text { This code should be used on } \\
\text { passages that emphasize } \\
\text { partnership in a general }\end{array}$ & $\begin{array}{l}\text { Do NOT use this code for } \\
\text { passages that fit under one of } \\
\text { the subcategories. }\end{array}$ & $\begin{array}{l}\text { "The MYSA bar is set a } \\
\text { little low, so much more } \\
\text { could be accomplished }\end{array}$ \\
\hline
\end{tabular}




\begin{tabular}{|c|c|c|c|c|c|}
\hline & $\begin{array}{c}\text {-facilitation } \\
\text {-enhancing community } \\
\text { capacity }\end{array}$ & $\begin{array}{l}\text { (reciprocity of benefits } \\
\text { should primarily be } \\
\text { referring to the community, } \\
\text { not between an outside } \\
\text { organization and the } \\
\text { community) }\end{array}$ & manner. & & $\begin{array}{l}\text { with its brand power, } \\
\text { solidness of programs and } \\
\text { willingness on the part of } \\
\text { donors to fund." }\end{array}$ \\
\hline $\begin{array}{l}\text { 1. Awareness/ } \\
\text { Advocacy }\end{array}$ & $\begin{array}{c}\text { Key words: } \\
\text {-awareness campaigns } \\
\text {-promotion }\end{array}$ & $\begin{array}{l}\text { Partnership that helps } \\
\text { brings awareness and } \\
\text { advocacy to an } \\
\text { international level }\end{array}$ & $\begin{array}{l}\text { This code should be used to } \\
\text { describe advocacy that is } \\
\text { described with partnerships }\end{array}$ & & $\begin{array}{l}\text { "We are also passionate } \\
\text { about promoting and } \\
\text { raising awareness of the } \\
\text { use of sport for positive } \\
\text { change, and we play an } \\
\text { active part in several } \\
\text { international partnership } \\
\text { networks." }\end{array}$ \\
\hline $\begin{array}{l}\text { 2. Enhanced } \\
\text { Resources- } \\
\text { Knowledge Based }\end{array}$ & & $\begin{array}{l}\text { Partnership that is based on } \\
\text { building the community's } \\
\text { knowledge base. }\end{array}$ & $\begin{array}{l}\text { This code should be used to } \\
\text { describe passages that focus on } \\
\text { partnership efforts that increase } \\
\text { the community's capacity in } \\
\text { regards to knowledge and skill } \\
\text { base. }\end{array}$ & $\begin{array}{l}\text { This code is ONLY for } \\
\text { passages that focus on } \\
\text { partnership with outside } \\
\text { organizations to increase this } \\
\text { knowledge. }\end{array}$ & $\begin{array}{l}\text { "WhizzKids United starts } \\
\text { off by our team coming } \\
\text { into an agreement with a } \\
\text { school to implement our } \\
\text { interactive version of life } \\
\text { skills orientation for } \\
\text { students." }\end{array}$ \\
\hline $\begin{array}{c}\text { 3. Enhanced } \\
\text { Resources- Material } \\
\text { Based } \\
\end{array}$ & & $\begin{array}{l}\text { Partnership that is based on } \\
\text { building the community's } \\
\text { access to material } \\
\text { resources, including } \\
\text { funding, needed for } \\
\text { expansion and the program }\end{array}$ & $\begin{array}{l}\text { This code should be used to } \\
\text { describe passages that focus on } \\
\text { partnership efforts that increase } \\
\text { the community's capacity in } \\
\text { regards to monetary sources } \\
\text { and physical materials }\end{array}$ & $\begin{array}{l}\text { This code is ONLY for the } \\
\text { passages describing material } \\
\text { benefit of partnerships. }\end{array}$ & \\
\hline $\begin{array}{l}\text { 4. Resources- Power } \\
\text { Based }\end{array}$ & & $\begin{array}{l}\text { Partnership that is based on } \\
\text { building the community's } \\
\text { access to need political and } \\
\text { social power to make } \\
\text { lasting change }\end{array}$ & $\begin{array}{l}\text { This code should be used on } \\
\text { passages that focus on } \\
\text { partnership efforts that expand } \\
\text { political connections or } \\
\text { possibilities that allow access } \\
\text { to greater political power. }\end{array}$ & $\begin{array}{l}\text { This code is ONLY for use } \\
\text { on political and social } \\
\text { networking that allows more } \\
\text { access to power. }\end{array}$ & $\begin{array}{l}\text { "The United Health } \\
\text { Academy model presents } \\
\text { an exciting opportunity for } \\
\text { cooperation between } \\
\text { Africaid and government } \\
\text { health structures. This } \\
\text { partnership will allow for } \\
\text { capacity building to } \\
\text { develop a cooperative } \\
\text { relationship between the } \\
\text { clinic and schools." }\end{array}$ \\
\hline
\end{tabular}




\begin{tabular}{|c|c|c|c|c|}
\hline $\begin{array}{l}\text { 5. Plans for Growth } \\
\text { and Sustainability }\end{array}$ & $\begin{array}{l}\text { Programs and measures to } \\
\text { address issues are only as } \\
\text { good as their ability to be } \\
\text { sustained and grow. }\end{array}$ & $\begin{array}{l}\text { This code should be used for } \\
\text { any passage that focuses on } \\
\text { plans of sustainability and how } \\
\text { partnership will help enhance } \\
\text { the ability to sustain efforts as } \\
\text { well as allow them to grow. } \\
\text { This should be the primary } \\
\text { code that is used for any } \\
\text { sustainability measures, as they } \\
\text { are usually tied to community } \\
\text { growth. }\end{array}$ & $\begin{array}{l}\text { Do NOT use this code for } \\
\text { sustainability that speaks } \\
\text { about building local } \\
\text { ownership of the program } \\
\text { (local leaders etc.) as this } \\
\text { falls under building the } \\
\text { community capacity and } \\
\text { may or may not have to do } \\
\text { with partners' roles. }\end{array}$ & $\begin{array}{l}\text { "MYSA's rock solid } \\
\text { model has attracted the } \\
\text { interest of FIFA and } \\
\text { Nike's CSR programs." }\end{array}$ \\
\hline $\begin{array}{l}\text { 6. Role of SFW and } \\
\text { FIFA }\end{array}$ & $\begin{array}{l}\text { Partnership with SFW and } \\
\text { FIFA may offer all of the } \\
\text { above subcodes, but shows } \\
\text { that organization is willing } \\
\text { to connect with private } \\
\text { companies as well as } \\
\text { nonprofit networks }\end{array}$ & $\begin{array}{l}\text { This code should be used for } \\
\text { any passage that mentions } \\
\text { partnership between SFW and } \\
\text { FIFA, regardless of whether the } \\
\text { code can fall in another } \\
\text { partnership category. }\end{array}$ & & $\begin{array}{c}\text { "The development is part } \\
\text { of the } 20 \text { Centres for } 2010, \\
\text { the official legacy } \\
\text { campaign of the } 2010 \\
\text { World Cup in South Africa } \\
\text { and will include } \\
\text { classrooms, a health clinic, } \\
\text { office space and an } \\
\text { Astroturf football pitch." }\end{array}$ \\
\hline
\end{tabular}


Appendix C

Codebook Instructions 


\section{Instructions for Coding}

Thank you for agreeing to participate as a coder in this study. To allow for better reliability measures you should only code from the instructions listed on this sheet. Code to the best of your ability; if the codebook is unclear, you will have a discussion with the primary researcher at the conclusion of the pilot coding to adjust definitions you found to be problematic.

The purpose of this coding is to examine promotional materials from three "best practice" sport-for-development organizations, to examine whether the materials reflect stated aspects of sport-for-development programs, and the tenets of the Community Organization Health Model. There is no right or wrong in when it comes to coding, and it may be possible that you use a code more frequently or not at all. You are only testing for the presence of these coding concepts. Only code the material as reflecting each category/subcategory if it DIRECTLY reflects the definition/examples that are given in the following code book. To ensure there is no bias in coding, you will not be informed as to the full purpose of this study.

Below you will find a comprehensive definition of each health organization model tenet, along with a specific codebook that you can use as reference when the documents are in your possession.

\section{Sport-for-Development}

Development. Process of enlarging peoples' choices and increasing opportunities available to all members of society (UN Task Force, 2003)

Sport. All forms of physical activity that contribute to physical fitness, mental well-being and social interaction (UN Task Force, 2003)

Sport for Development (SFD). The intentional use of sport, physical activity and play to attain specific development and peace objectives, including the Millennium Health Goals (Right to Play 2008, pg 13).

\section{Community Organization Health Model}

The goal of the COHM is to help groups identify common problems or goals, mobilize resources, and implement strategies for reaching collective goals (Minkler \& Wallerstein, 2002). The COHM seeks to meet the community where it is, rather than imposing external need assessment and priorities in development efforts. Community ownership is emphasized to encourage sustainability and maintain development (Minkler $\&$ Wallerstein, 2002). While there are a variety of models under which community organization can function, the following concepts are found across all models, and appear to be natural pillars from which programs can be evaluated: empowerment, critical consciousness, community capacity, issue selection, social capital, and participation \& relevance (Minkler \& Wallerstein, 2002). 
When examining the way in which the COHM works, it helps to understand how "community" is defined. While community can be defined in a variety of ways, meaning different things depending upon the cultural context, it will generally come to refer to individuals fitting into at least one of the following categories: 1) categorical community: based on geographical location, occupation, or gender, 2) ecological systems community: based on population characteristics (size, technology exposure etc.) or 3) social systems community: based on social, political or economic interactions (Minkler \& Wallerstein, 2002). It is important, before using the COHM, to identify both individuals who will serve as agents of change as well as identify the characteristics that unite the community.

\section{COHM Tenets}

Empowerment is defined as the "social action process for people to gain mastery over their lives and the lives of their community" (Minkler \& Wallerstein, 2002, pg 288). It highlights an emphasis on achieving community equity and building competency within the political sector (Minkler \& Wallerstein, 2002). An empowered community, that lacks political competency, may be very good at expressing what they need, without the ability to obtain the necessary resources for change. The process of empowerment can and should occur on three levels: individual, organizational and community. The key is to articulate a broader vision for the community and sustain efforts to realize that vision (Minkler and Wallerstein, 2002).

Critical consciousness refers to "consciousness based on reflection and action in making change" (Minkler \& Wallerstein, 2002, pg 288). Critical consciousness is the engagement of dialogue that stems from empowered individuals (Minkler \& Wallerstein, 2002). As the strength of a community grows, there will be expanded discussion about the causes of societal problems and the actions the community should take in order to address these concerns. It is important for continual evaluation to occur to maintain a quality gauge on the needs of the community.

Issue selection becomes pivotal when it comes to sustaining a community effort. It refers to the ability to "identify winnable and specific targets of change that unify and build community strength" (Minkler \& Wallerstein, 2002, pg 288). These issues are primarily identified through the participation of the community, but it is the leader's role to focus attention on the issues that are most feasible. These issues should also be articulated to the community in such a way that community members are able to reiterate them in one simple sentence (Minkler \& Wallerstein, 2002).

Community capacity describes the "characteristics of community affecting its ability to identify, mobilize, and address problems" (Minkler \& Wallerstein, 2002, pg 288). A community's capacity depends upon: 1) skills and resources, 2) critical reflection of needs, 3) sense of community, 4) understanding of history and culture and 5) articulation of values. Each of the needs build on the others; all five must be present for a community to be at its full capacity. The cohesion of all of these elements often lies in the concept of "social capital." 
Social capital refers to the relationships between community members, defined by trust, reciprocity and civic engagement (Minkler \& Wallerstein, 2002, pg 288). Communities with social capital are better able to facilitate cooperation among community members for mutual benefit. To build social capital, members of the society must perceive that the relationships they form to are horizontal in nature, with all individual working toward the betterment of the community (Kreuter, Lezin \& Koplan, 1997).

Finally, any successful program, that gets the community to take ownership (through participation and relevance), must start at the grassroots level and work to give them the reigns in determining program direction and effect. All members of the community should have equal access to the power and resources in community organization programs (Minkler \& Wallerstein, 2002). In addition, to ensure continued relevance, leadership should not be maintained by a non-local leader. The more a program can seek to maintain local leadership, while creating connections with outside partnerships for continued sustainability, the greater community ownership and success the program will experience.

Since these definitions encompass a large amount of data the following summarization flow chart should be kept in mind while coding (and should serve to help differentiate between similar sounding sub-codes in each category.

Preparation for action
Evaluating action
COHM Tenet

(1)

Empowerment

Course of action + Enhancin g action

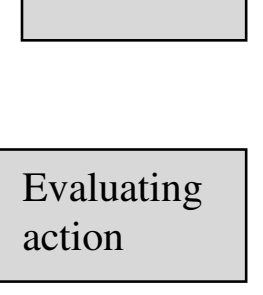

\begin{tabular}{|c|c|c|}
\hline COHM Tenet & Brief Summary & $\begin{array}{c}\text { How it Connects to Other } \\
\text { Tenets }\end{array}$ \\
\hline Empowerment & $\begin{array}{l}\text { Preparing and building for } \\
\text { action }\end{array}$ & $\begin{array}{l}\text { Focuses on the individual, } \\
\text { indirectly strengthening the } \\
\text { community whole }\end{array}$ \\
\hline Critical Consciousness & Discussing action & $\begin{array}{c}\text { Focused on multiple people in } \\
\text { dialogue }\end{array}$ \\
\hline Issue Selection & Deciding on action & $\begin{array}{c}\text { Engaging whole community in } \\
\text { decision }\end{array}$ \\
\hline Community Capacity & $\begin{array}{c}\text { Current resources of } \\
\text { community and ability to gain } \\
\text { additional }\end{array}$ & $\begin{array}{c}\text { The collective value and } \\
\text { strength of the community }\end{array}$ \\
\hline Social Capital & $\begin{array}{l}\text { Expanding resources through } \\
\text { strengthening community } \\
\text { interactions }\end{array}$ & $\begin{array}{c}\text { Greater social capital } \\
\text { enhances the Community } \\
\text { Capacity and allows for more } \\
\text { effective action }\end{array}$ \\
\hline Participation \& Relevance & $\begin{array}{c}\text { Relevance of actions through } \\
\text { eyes of evaluation and } \\
\text { accountability }\end{array}$ & $\begin{array}{c}\text { Ensures the chosen action and } \\
\text { implementation are engaging } \\
\text { community ownership and } \\
\text { relevant }\end{array}$ \\
\hline
\end{tabular}

\section{The Coding Process}

To code correctly, you need to read the following documents in "units." Since these documents can vary in length, a unit is considered three sentences in a document 


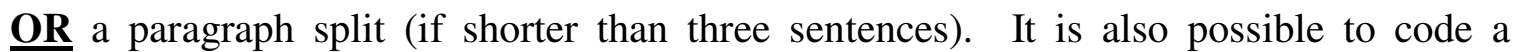
sentence or two within a long paragraph as a unit, if there is a distinct shift in emphasis and meaning. Every three sentences should have a "code."

If no code is applicable for a section, you can leave it intentionally uncodedsimply de-note "No code" in the margins. If you feel that no code exists that properly fits that section, but see a reappearing theme, feel free to write this in the margins. No code should ONLY be used if there is absolutely no code that appears to fit.

If a section encompasses multiple codes, simply code it for both. While it is natural to have some simultaneous coding happen, attempt to find the code that fits best over that section and only code simultaneously if key words or ideas appear in the same unit together.

You will be given as much as time as you need to code the documents. After the coding process has been completed, you will engage in a discussion with the primary researcher to examine the amount of agreement found in the coded documents. Remember, there is no right or wrong way to code, simply attempt to code areas of the document that appear to reflect what is found in the code book. Do not feel obligated to fit a code to the content, if the content does not appear to reflect any of the codes.

You will code one of each of the following documents: one evaluation of each program, one transcribed promotional video, one personal testimony from a program participant and the general mission/purpose statements of each organization. 
Appendix D

Final Codebook 


\begin{tabular}{|c|c|c|c|c|c|}
\hline & Brief Definition & Full Definition & Inclusion & Exclusion & Example \\
\hline $\begin{array}{l}\text { Sport/Football- for- } \\
\text { Development } \\
\text { General (SFD-G) }\end{array}$ & & $\begin{array}{c}\text {-Utilization of sport } \\
\text { (football) as a tool to foster } \\
\text { personal and social } \\
\text { improvements of those } \\
\text { people and communities } \\
\text { most in need of } \\
\text { development }\end{array}$ & $\begin{array}{l}\text { This code should be used when } \\
\text { general benefits of program are } \\
\text { described or when overarching } \\
\text { mission statements covering } \\
\text { multiple coding categories are } \\
\text { presented }\end{array}$ & $\begin{array}{l}\text { Do NOT this code for } \\
\text { anything that can be coded } \\
\text { under the below } \\
\text { subcategories }\end{array}$ & $\begin{array}{l}\text { "Embracing a vision of } \\
\text { using sports to effect } \\
\text { positive social change to } \\
\text { underprivileged } \\
\text { communities" }\end{array}$ \\
\hline $\begin{array}{l}\text { 1. Unification of } \\
\text { Community (SFD-1) }\end{array}$ & $\begin{array}{l}\text { Key words: } \\
\text { Football unites the } \\
\text { community, crosses } \\
\text { cultural boundaries }\end{array}$ & $\begin{array}{l}\text {-Sport's potential to bring } \\
\text { individuals from different } \\
\text { parts of the community } \\
\text { together as one. }\end{array}$ & $\begin{array}{l}\text { This code should be used when } \\
\text { passages describe the benefit of } \\
\text { using sport to GATHER AND } \\
\text { SUPPORT COMMUNITY }\end{array}$ & & $\begin{array}{l}\text { "In most places, simply } \\
\text { arriving at a field with a } \\
\text { soccer ball will win you } \\
\text { instant friendships and } \\
\text { immediate access into } \\
\text { local community." }\end{array}$ \\
\hline 2. Youth (SFD-2) & $\begin{array}{l}\text { Key words: } \\
\text { Football is well suited } \\
\text { to attract youth's } \\
\text { interest }\end{array}$ & $\begin{array}{l}\text {-Due to the ease of } \\
\text { administration and } \\
\text { popularity of the sport, } \\
\text { football engages youth } \\
\text { more than other sports }\end{array}$ & $\begin{array}{c}\text { This code should only be used } \\
\text { to describe instances that } \\
\text { football is emphasized as a } \\
\text { powerful tool for attracting } \\
\text { YOUTH. }\end{array}$ & $\begin{array}{l}\text { Do NOT use this code to } \\
\text { describe any unification of } \\
\text { community outside of } \\
\text { attracting YOUTH. }\end{array}$ & $\begin{array}{l}\text { "Every football team is a } \\
\text { "mobilized" youth group." }\end{array}$ \\
\hline $\begin{array}{l}\text { 3. Gender Equity } \\
\text { (SFD-3) }\end{array}$ & $\begin{array}{l}\text { Key words: } \\
\text { Research has shown } \\
\text { SFD to be useful to } \\
\text { gender equity purposes }\end{array}$ & $\begin{array}{l}\text { The active use of sport to } \\
\text { engage females to break } \\
\text { barriers of stigma and } \\
\text { discrimination based upon } \\
\text { gender roles }\end{array}$ & $\begin{array}{l}\text { This code should be used to } \\
\text { code pieces of information that } \\
\text { emphasize why sport is well } \\
\text { suited for addressing GENDER } \\
\text { DISPARTITIES OR } \\
\text { EQUALITY }\end{array}$ & $\begin{array}{l}\text { This code should NOT be } \\
\text { used to described the specific } \\
\text { process of HOW sport is } \\
\text { used (i.e. through } \\
\text { empowering girls etc.), but } \\
\text { just emphasizes that gender } \\
\text { equality and female } \\
\text { participation is important }\end{array}$ & $\begin{array}{l}\text { "Girls should have the } \\
\text { same access to public } \\
\text { space and social visibility } \\
\text { as the boys in a } \\
\text { community." }\end{array}$ \\
\hline \multicolumn{6}{|c|}{$\begin{array}{l}\text { **:Special note: The SFD codes should only be used when a unit is talking BROADLY about the benefits of sport in one of the subcategories. This code should NOT be } \\
\text { used when a unit is talking about the benefit of sport in a more specific way- i.e. "football empowers individuals by allowing them access to a better education." SFD fits } \\
\text { within many of the subcategories, as this information is about SFD programs. SFD codes are simply meant to catch the few areas that SFD are said to be particularly } \\
\text { important outside the COHM tenets** }\end{array}$} \\
\hline $\begin{array}{l}\text { Empowerment } \\
\text { (E-G) }\end{array}$ & $\begin{array}{c}\text { Key words: } \\
\text {-Break expectations and } \\
\text { stigma }\end{array}$ & $\begin{array}{l}\text { Enabling process thru } \\
\text { which individuals or } \\
\text { communities take control } \\
\text { over life and environment } \\
\text {-Multilayered- individual, } \\
\text { community \& organization }\end{array}$ & $\begin{array}{l}\text { This code should be used if the } \\
\text { passage makes reference to } \\
\text { empowerment at the individual } \\
\text { level OR for discussion of } \\
\text { empowerment NOT covered } \\
\text { under the subcategories }\end{array}$ & $\begin{array}{l}\text { Do NOT use this code for } \\
\text { any data that refers to one of } \\
\text { the four subcategories }\end{array}$ & $\begin{array}{l}\text { “...worked directly with } \\
\text { programs designed to } \\
\text { empower youth and make } \\
\text { meaningful changes in the } \\
\text { lives of children and } \\
\text { communities." }\end{array}$ \\
\hline
\end{tabular}




\begin{tabular}{|c|c|c|c|c|c|}
\hline & & $\begin{array}{l}\text { BUT all subcategories will } \\
\text { reflect primarily an } \\
\text { INDIVIDUAL focus }\end{array}$ & & & \\
\hline $\begin{array}{l}\text { 1.Competence/ } \\
\text { Self-Efficacy } \\
\text { (E1) }\end{array}$ & $\begin{array}{l}\text { Key words: } \\
\text {-self-esteem } \\
\text {-self-worth } \\
\text {-self-efficacy }\end{array}$ & $\begin{array}{l}\text { Specific measures that have } \\
\text { been taken to increase an } \\
\text { individual competency in } \\
\text { political and social areas } \\
\text { and his/her belief in his/her } \\
\text { potential for success }\end{array}$ & $\begin{array}{l}\text { This code should be used if the } \\
\text { passage refers to empowerment } \\
\text { that focuses on building SELF- } \\
\text { CONCEPT }\end{array}$ & $\begin{array}{l}\text { This code should NOT be } \\
\text { used to describe self- } \\
\text { confidence }\end{array}$ & $\begin{array}{l}\text { "The goal is to empower } \\
\text { youth with critical life } \\
\text { skills including self- } \\
\text { esteem, teamwork, } \\
\text { discipline and decision- } \\
\text { making." }\end{array}$ \\
\hline $\begin{array}{l}\text { 2.Hope/Optimism } \\
\text { (E2) }\end{array}$ & $\begin{array}{l}\text { Key words: } \\
\text {-enable hope } \\
\text {-optimism } \\
\text {-resilience }\end{array}$ & $\begin{array}{l}\text { Empowerment that focuses } \\
\text { on reframing participant's } \\
\text { view of the HIV problem in } \\
\text { a positive, hopeful light. }\end{array}$ & $\begin{array}{l}\text { This code should be used to } \\
\text { describe the psychological } \\
\text { effects of POSITIVE } \\
\text { THINKING and empowering } \\
\text { youth to think optimistically }\end{array}$ & & $\begin{array}{l}\text { "It helps them take small } \\
\text { steps to achieve their goals } \\
\text { and are resilient when } \\
\text { faced with challenges... } \\
\text { believing they can protect } \\
\text { themselves and others } \\
\text { from HIV." }\end{array}$ \\
\hline $\begin{array}{l}\text { 3.Knowledge/ } \\
\text { Achievement } \\
\text { (E3) }\end{array}$ & $\begin{array}{l}\text { Key words: } \\
\text {-educate } \\
\text {-determination } \\
\text {-achievement }\end{array}$ & $\begin{array}{l}\text { This element of } \\
\text { empowerment specifically } \\
\text { refers to all measures meant } \\
\text { to empower individuals } \\
\text { through providing access to } \\
\text { education and knowledge } \\
\text { that can increase their } \\
\text { capacity }\end{array}$ & $\begin{array}{l}\text { This code should be used to } \\
\text { code any passage that refers to } \\
\text { education, or increasing an } \\
\text { individual's capability through } \\
\text { any sort of formal } \\
\text { EDUCATION/SKILL } \\
\text { DEVELOPMENT. }\end{array}$ & $\begin{array}{l}\text { This code should NOT be } \\
\text { used to code for group or } \\
\text { community } \\
\text { knowledge/achievement }\end{array}$ & \\
\hline $\begin{array}{l}\text { 4. Mastery of Self/ } \\
\text { Responsibility } \\
\text { (E4) }\end{array}$ & $\begin{array}{c}\text { Key words: } \\
\text {-mastery of self/life } \\
\text {-responsibility for role } \\
\text {-legitimize place in } \\
\text { society } \\
\text {-self confidence }\end{array}$ & $\begin{array}{l}\text { Growing in the capacity } \\
\text { and confidence to accept } \\
\text { social role in making } \\
\text { change in community. } \\
\text { Finding ways to change } \\
\text { society within the confines } \\
\text { of current infrastructures }\end{array}$ & $\begin{array}{l}\text { This code should be used for } \\
\text { passages that emphasize } \\
\text { breaking social norms and } \\
\text { acknowledging that the } \\
\text { individual has a meaningful } \\
\text { place in society, outside the } \\
\text { social norms. Primarily used } \\
\text { for more POLITICAL AND } \\
\text { SOCIAL EMPOWERMENT }\end{array}$ & $\begin{array}{l}\text { Do NOT use this code for } \\
\text { passage if is speaking about } \\
\text { building knowledge or } \\
\text { achievement, this } \\
\text { empowerment is political } \\
\text { and social in nature. }\end{array}$ & \\
\hline \multicolumn{6}{|c|}{$\begin{array}{l}\text { When differentiating between types of empowerment the following differentiations need to be made distinct...1) Knowledge is only about the process of empowering } \\
\text { someone through gaining knowledge. It is not talking about increasing competence through knowledge, as knowledge is just one way of increasing feelings of } \\
\text { competence. Gaining knowledge does not necessarily translate into high self-efficacy or confidence. 2) Self efficacy- belief in ability successfully complete certain tasks. } \\
\text { Self-confidence- belief in self-worth and ability to succeed, a combination of efficacy and esteem. Competency and self-efficacy are the beginning stages of an empowered } \\
\text { individual, self-confidence and personal ownership are the final stages. }\end{array}$} \\
\hline
\end{tabular}




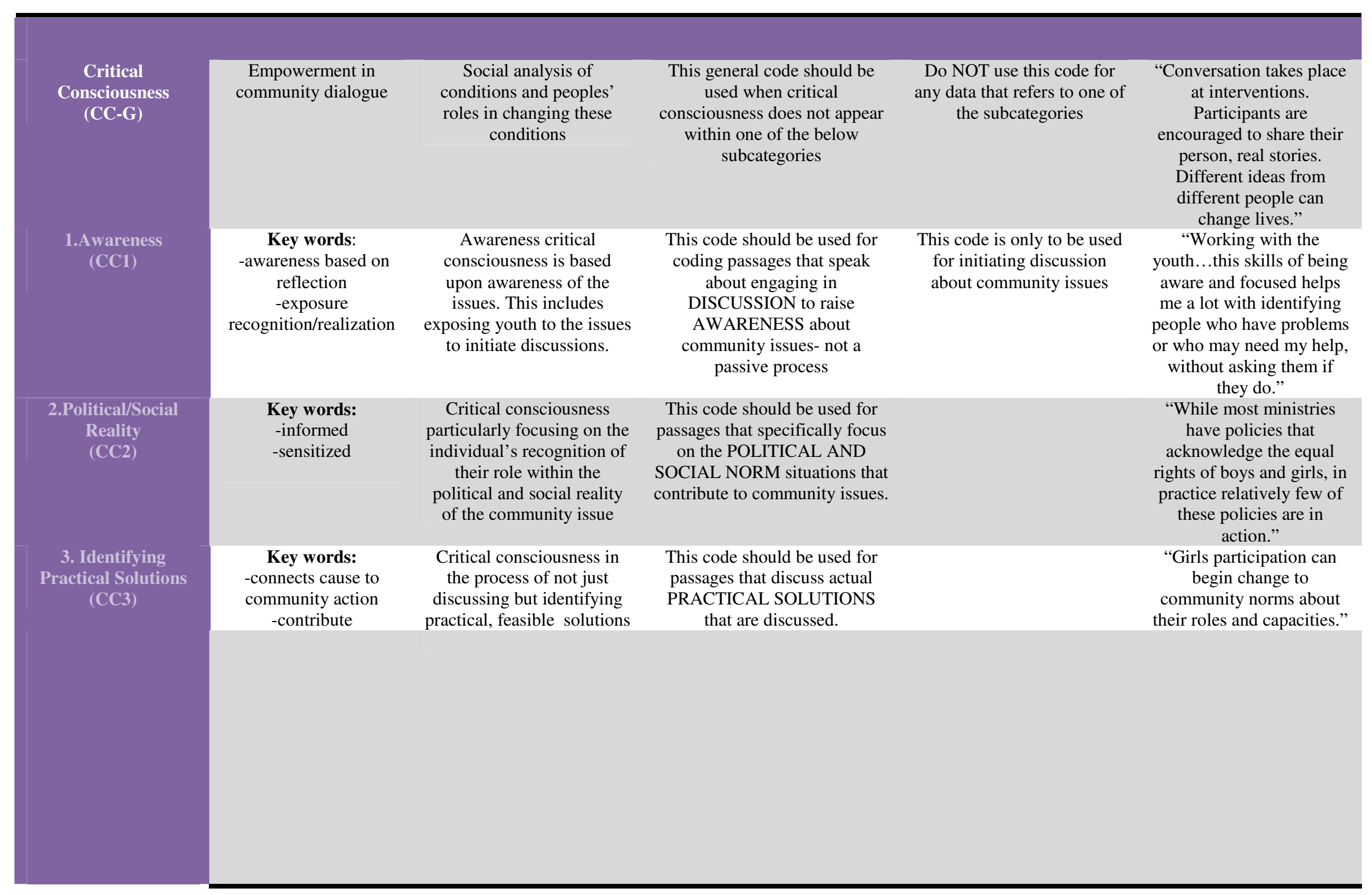




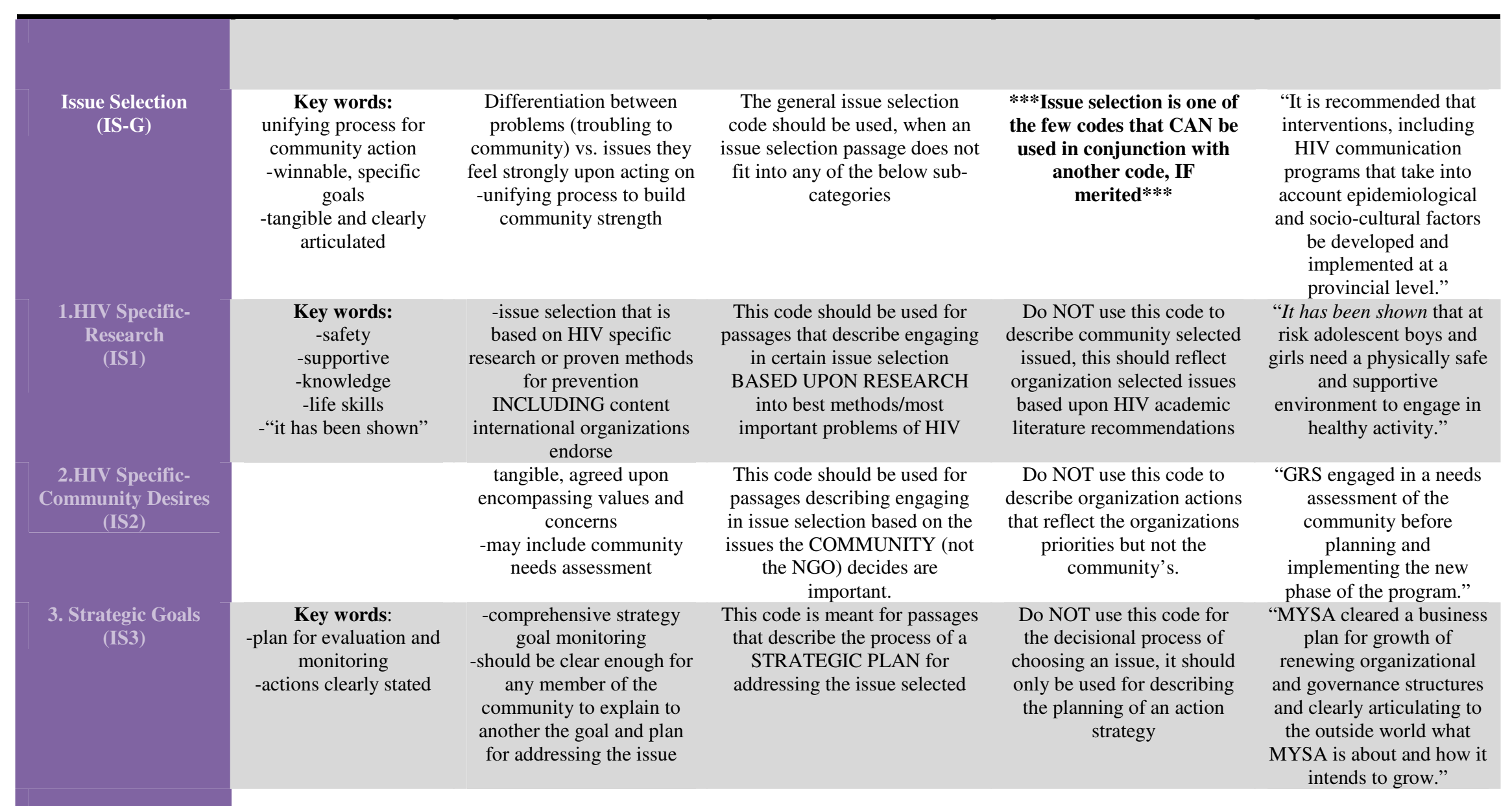




\begin{tabular}{|c|c|c|c|c|c|}
\hline $\begin{array}{c}\text { Community Capacity } \\
\text { (CCom-G) }\end{array}$ & & $\begin{array}{l}\text { CURRENT Characteristics } \\
\text { of the community that } \\
\text { allow the ability to identify, } \\
\text { mobilize and address social } \\
\text { and health concerns }\end{array}$ & $\begin{array}{l}\text { This code should be used for } \\
\text { any passage that speaks about } \\
\text { community capacity in a } \\
\text { generic way and/or does not fit } \\
\text { within any of the subcategories }\end{array}$ & $\begin{array}{l}\text { Do NOT use this code for } \\
\text { any data that refers to one of } \\
\text { the subcategories }\end{array}$ & \\
\hline $\begin{array}{l}\text { 1.Access } \\
(\text { CCom } 1)\end{array}$ & & $\begin{array}{l}\text { Part of a community's } \\
\text { capacity is its access to } \\
\text { resources that could be used } \\
\text { to address issues }\end{array}$ & $\begin{array}{l}\text { This code should be used for } \\
\text { any passage that speaks about } \\
\text { current LEVEL OF ACCCESS } \\
\text { or ways to gain additional } \\
\text { access to resources }\end{array}$ & $\begin{array}{l}\text { Do NOT use this code that } \\
\text { addresses the capacity of the } \\
\text { community to actually USE } \\
\text { resources at their disposal, } \\
\text { this only houses discussion } \\
\text { of accessing resources. }\end{array}$ & $\begin{array}{l}\text { "Outside the classroom, } \\
\text { "Team Talk" Peer } \\
\text { Education also serves as } \\
\text { an approachable front-line } \\
\text { resource of help for } \\
\text { troubled youth who might } \\
\text { be too intimidated to go to } \\
\text { an authority figure. Peer } \\
\text { leaders have HIV } \\
\text { education and can help } \\
\text { peers can access to HIV } \\
\text { clinics." }\end{array}$ \\
\hline $\begin{array}{l}\text { 2. Mobilization } \\
\text { (CCom2) }\end{array}$ & $\begin{array}{c}\text { Key Words: } \\
\text {-Community leaders } \\
\text { willing to take } \\
\text { ownership of leading } \\
\text { programs }\end{array}$ & $\begin{array}{l}\text { The community's capacity } \\
\text { to move resources in a } \\
\text { direction that allows them } \\
\text { to actually address the } \\
\text { issue. The movement of } \\
\text { resources }\end{array}$ & $\begin{array}{l}\text { This code should be used for } \\
\text { any passage that speaks about } \\
\text { actually UTILIZING the } \\
\text { resources to directly address } \\
\text { the problem. }\end{array}$ & $\begin{array}{l}\text { Do NOT use this code for } \\
\text { anything other than } \\
\text { discussion of targeting } \\
\text { resources on action toward } \\
\text { the problem }\end{array}$ & \\
\hline $\begin{array}{l}\text { 3. Shared Expertise } \\
\text { (CCom3) }\end{array}$ & & $\begin{array}{l}\text { Capacity of the community } \\
\text { to interact with experts both } \\
\text { locally and from } \\
\text { international locations to } \\
\text { continue expanding } \\
\text { resources and ideas for } \\
\text { addressing the issues }\end{array}$ & $\begin{array}{l}\text { This code should be used for } \\
\text { passages that talk about the } \\
\text { COLLECTIVE EXPERTISE } \\
\text { OF THE COMMUNITY or } \\
\text { individual's effort to increase } \\
\text { the expertise of the locals. }\end{array}$ & $\begin{array}{l}\text { Do NOT use this to talk } \\
\text { about knowledge } \\
\text { development (this skill } \\
\text { development should fall } \\
\text { under empowerment) } \\
\text { UNLESS it is for the specific } \\
\text { purpose of expanding the } \\
\text { community's capacity, in } \\
\text { which case it should be } \\
\text { coded as below }\end{array}$ & $\begin{array}{l}\text { "Teachers are very } \\
\text { satisfied with the program } \\
\text { and would like to see more } \\
\text { ways to sustain the results, } \\
\text { including helping them be } \\
\text { more involved in the } \\
\text { educational process." }\end{array}$ \\
\hline $\begin{array}{l}\text { 4. Collective Skills \& } \\
\text { Education } \\
\text { (CCom4) }\end{array}$ & & $\begin{array}{l}\text { The collective skills and } \\
\text { education of the } \\
\text { community. }\end{array}$ & $\begin{array}{l}\text { This code should be used for } \\
\text { passages that analyze the } \\
\text { current levels of }\end{array}$ & $\begin{array}{l}\text { This skill development does } \\
\text { not fall under empowering } \\
\text { education, as this is specific }\end{array}$ & $\begin{array}{l}\text { "A limiting factor in } \\
\text { growth will be staff that } \\
\text { lack the core skills and }\end{array}$ \\
\hline
\end{tabular}




\begin{tabular}{|c|c|c|c|c|c|}
\hline & & & $\begin{array}{l}\text { SKILL/KNOWLEDGE in the } \\
\text { community and/or plan for } \\
\text { INCREASING that capacity }\end{array}$ & $\begin{array}{c}\text { training for local community } \\
\text { members to continue to the } \\
\text { work toward resolving the } \\
\text { issue }\end{array}$ & $\begin{array}{c}\text { capacities necessary to } \\
\text { take programs to the next } \\
\text { level." }\end{array}$ \\
\hline $\begin{array}{l}\text { Social Capital } \\
\quad \text { (SC-G) }\end{array}$ & & $\begin{array}{c}\text {-coordination and } \\
\text { cooperation for mutual } \\
\text { benefit } \\
\text {-horizontal relationship of } \\
\text { power } \\
\text {-relationships of equity }\end{array}$ & $\begin{array}{l}\text { This code should be used for } \\
\text { any general concept of social } \\
\text { capital or the lack of ability to } \\
\text { use one of the subcategories. }\end{array}$ & $\begin{array}{c}\text { Do NOT use this code for } \\
\text { any data that refers to one of } \\
\text { the subcategories }\end{array}$ & $\begin{array}{l}\text { "You do something, I do } \\
\text { something; you do } \\
\text { nothing, I do nothing. } \\
\text { Youth seem to interact } \\
\text { with this concept with } \\
\text { great ease and appreciated } \\
\text { the meaning and } \\
\text { responsibility behind it." }\end{array}$ \\
\hline $\begin{array}{l}\text { 1.Trust \& Respect } \\
\text { Relations } \\
\text { (SC1) }\end{array}$ & $\begin{array}{l}\text { Key words: } \\
\text {-trust } \\
\text {-respect } \\
\text {-reciprocity }\end{array}$ & $\begin{array}{l}\text { Social capital related to } \\
\text { taking measures to build } \\
\text { trust and respect between } \\
\text { community members }\end{array}$ & $\begin{array}{l}\text { This code should be used for } \\
\text { any passages that are speaking } \\
\text { of processes in place to BUILD } \\
\text { TRUST, RESPECT AND } \\
\text { UNITY in the community }\end{array}$ & $\begin{array}{l}\text { Do NOT use this code to } \\
\text { describe the reciprocal } \\
\text { relationships that result from } \\
\text { this trust and respect. }\end{array}$ & $\begin{array}{l}\text { "Half of all elected MYSA } \\
\text { leaders are girls, including } \\
\text { the elected chair of the } \\
\text { overall MYSA Executive } \\
\text { Council" }\end{array}$ \\
\hline $\begin{array}{l}\text { 2. Helping Self \& } \\
\text { Community } \\
\text { (SC2) }\end{array}$ & $\begin{array}{l}\text { Key words: } \\
\text {-exchange }\end{array}$ & $\begin{array}{c}\text { Social capital as it } \\
\text { emphasizes the mutual } \\
\text { benefit of helping self and } \\
\text { community }\end{array}$ & $\begin{array}{l}\text { This code should be used for } \\
\text { any passages that speak about } \\
\text { RECIPROCAL } \\
\text { RELATIONSHIPS or } \\
\text { community stakeholders. }\end{array}$ & $\begin{array}{l}\text { Do NOT use this code to } \\
\text { describe the reciprocal } \\
\text { relationship that should exist } \\
\text { between an org and } \\
\text { community and/or outside } \\
\text { partners. This code is talking } \\
\text { about these relationships in } \\
\text { the community. }\end{array}$ & $\begin{array}{l}\text { "The main goal and motto } \\
\text { of MYSA is to "give youth } \\
\text { a sporting chance" to help } \\
\text { themselves and their } \\
\text { community" }\end{array}$ \\
\hline $\begin{array}{l}\text { 3. Civic Engagement } \\
\text { (SC3) }\end{array}$ & $\begin{array}{c}\text { Key words: } \\
\text {-stakeholders } \\
\text {-investment } \\
\text {-articulation of values }\end{array}$ & $\begin{array}{l}\text { Social capital as it is } \\
\text { actually measureable with } \\
\text { the community's } \\
\text { involvement in action. }\end{array}$ & $\begin{array}{l}\text { This code should be used for } \\
\text { any passages that speak about } \\
\text { actual COMMUNITY } \\
\text { INVOLVEMENT in } \\
\text { addressing the issue }\end{array}$ & & $\begin{array}{c}\text { "Our boys and girls play } \\
\text { football matches, but also } \\
\text { carry out a wide range of } \\
\text { environmental cleanup and } \\
\text { other self-help community } \\
\text { service activities." }\end{array}$ \\
\hline \multicolumn{6}{|c|}{$\begin{array}{l}\text { Social capital is the utilization of a human resource and the expansion of community capacity to act and gain ownership, but it is not in } \\
\text { and of itself the end result of relevant leadership. It is focused on resource utilization and relationship building, HOPEFULLY, in a } \\
\text { relevant way. It is also possible to have civic engagement without the leader being found in the community. }\end{array}$} \\
\hline
\end{tabular}




\begin{tabular}{|c|c|c|c|c|c|}
\hline $\begin{array}{l}\text { Participation \& } \\
\text { Relevance } \\
\text { (PR-G) }\end{array}$ & Key words: & $\begin{array}{c}\text { Creates an agenda based } \\
\text { upon felt needs, shared } \\
\text { power and awareness of } \\
\text { resources } \\
\text {-This includes helping to } \\
\text { transfer leadership to local } \\
\text { leaders as well as } \\
\text { decentralization of foreign } \\
\text { leadership (move into a } \\
\text { partner role) }\end{array}$ & $\begin{array}{l}\text { This code should be used to } \\
\text { code any passages that talk } \\
\text { about the concepts of building } \\
\text { GREATER COMMUNITY } \\
\text { PARTICIPATION and/or } \\
\text { altering the program to make it } \\
\text { more relevant }\end{array}$ & $\begin{array}{l}\text { Do NOT use this code for } \\
\text { any data that refers to one of } \\
\text { the subcategories }\end{array}$ & $\begin{array}{l}\text { "The WhizzKids United } \\
\text { Health Academy provides } \\
\text { a holistic range of services } \\
\text { free of charge in an } \\
\text { adolescent-friendly, non- } \\
\text { judgmental environment, } \\
\text { and it gives kids a venue } \\
\text { of which they can take } \\
\text { ownership and see it as } \\
\text { "their place." }\end{array}$ \\
\hline $\begin{array}{l}\text { 1.Evaluation/ } \\
\text { Progression } \\
\text { (PR1) }\end{array}$ & $\begin{array}{c}\text { Key Words: } \\
\text {-impact assessments } \\
\text {-evaluation/community } \\
\text { feedback in process }\end{array}$ & $\begin{array}{l}\text { Addressing the continued } \\
\text { relevance and growth of the } \\
\text { program through valuing } \\
\text { evaluation and hearing } \\
\text { community feedback. }\end{array}$ & $\begin{array}{l}\text { This code should be used for } \\
\text { any passages that reflect } \\
\text { EVALUATION MEASURES } \\
\text { (describing how and when) as } \\
\text { well as mention of } \\
\text { CONTINUED GROWTH } \\
\text { PLANS }\end{array}$ & $\begin{array}{l}\text { Do NOT use this code to } \\
\text { describe the content of an } \\
\text { evaluation. }\end{array}$ & $\begin{array}{l}\text { "GRS is at the cutting } \\
\text { edge of curriculum } \\
\text { development. With the } \\
\text { understanding that it is } \\
\text { never static- they are } \\
\text { always incorporating } \\
\text { community feedback, both } \\
\text { formal and informal to } \\
\text { make it better." }\end{array}$ \\
\hline $\begin{array}{l}\text { 2. Culturally } \\
\text { Appropriate } \\
\text { Implementation } \\
\text { (PR2) }\end{array}$ & $\begin{array}{l}\text { Key Words: } \\
\text {-integration }\end{array}$ & $\begin{array}{l}\text { Culturally appropriate is a } \\
\text { combination of appropriate } \\
\text { evaluation measures and } \\
\text { focusing on altering } \\
\text { programs as need be due to } \\
\text { response }\end{array}$ & $\begin{array}{l}\text { This code should be used to } \\
\text { describe the CONTENT AND } \\
\text { METHOD of evaluations as } \\
\text { well as ways to keep } \\
\text { ACCOUNTABLE for the goals } \\
\text { set for program implementation }\end{array}$ & $\begin{array}{l}\text { Do NOT use this code for } \\
\text { more general discussion of } \\
\text { the evaluation. }\end{array}$ & $\begin{array}{l}\text { "Most are top players...the } \\
\text { best players are the best } \\
\text { way to reach many other } \\
\text { youth with crucial } \\
\text { information." }\end{array}$ \\
\hline $\begin{array}{l}\text { 3. Owned and } \\
\text { Managed By } \\
\text { Community } \\
\text { (PR3) }\end{array}$ & $\begin{array}{c}\text { Key Words: } \\
\text {-community of equals } \\
\text {-decentralization } \\
\text {-community determines } \\
\text { direction and input } \\
\text {-local leadership } \\
\text { executed (ownership) }\end{array}$ & $\begin{array}{l}\text { Organizations should work } \\
\text { toward as much local } \\
\text { leadership as possible, } \\
\text { including plans of } \\
\text { decentralizing the use of } \\
\text { outsiders }\end{array}$ & $\begin{array}{l}\text { This code should be used to } \\
\text { describe plans that allow } \\
\text { TRANSFERRING POWER } \\
\text { AND OWNERSHIP over to the } \\
\text { community }\end{array}$ & & $\begin{array}{l}\text { "Hundreds of MYSA } \\
\text { youth leaders between 13- } \\
20 \text { years old have been } \\
\text { training on AIDS } \\
\text { prevention and peer } \\
\text { counseling." }\end{array}$ \\
\hline
\end{tabular}

The actual content of the program and its relevance will be commented on in the above tenets (empowerment $\rightarrow$ social capital) - P\&R 


\begin{tabular}{|c|c|c|c|c|c|}
\hline $\begin{array}{l}\text { Partnership \& } \\
\text { Sustainability } \\
\text { (PS-G) }\end{array}$ & $\begin{array}{c}\text { Key Words: } \\
\text {-investment } \\
\text {-consultation } \\
\text {-expertise } \\
\text {-facilitation } \\
\text {-enhancing community } \\
\text { capacity }\end{array}$ & $\begin{array}{l}\text { Partnership is not } \\
\text { necessarily focused on } \\
\text { reciprocity of benefits } \\
\text { (reciprocity of benefits } \\
\text { should primarily be } \\
\text { referring to the community, } \\
\text { not between an outside } \\
\text { organization and the } \\
\text { community) }\end{array}$ & $\begin{array}{c}\text { This code should be used on } \\
\text { passages that emphasize } \\
\text { partnership in a general } \\
\text { manner. }\end{array}$ & $\begin{array}{l}\text { Do NOT use this code for } \\
\text { any data that refers to one of } \\
\text { the subcategories }\end{array}$ & $\begin{array}{l}\text { "The MYSA bar is set a } \\
\text { little low; so much more } \\
\text { could be accomplished } \\
\text { with its brand power, } \\
\text { solidness of programs and } \\
\text { willingness on the part of } \\
\text { donors to fund." }\end{array}$ \\
\hline $\begin{array}{l}\text { 1. Awareness/ } \\
\text { Advocacy } \\
\text { (PS1) }\end{array}$ & $\begin{array}{c}\text { Key words: } \\
\text {-awareness campaigns } \\
\text {-promotion }\end{array}$ & $\begin{array}{c}\text { Partnership that helps } \\
\text { brings awareness and } \\
\text { advocacy to an } \\
\text { international level }\end{array}$ & $\begin{array}{l}\text { This code should be used to } \\
\text { describe ADVOCACY that is } \\
\text { present due to partnership }\end{array}$ & $\begin{array}{l}\text { Do NOT use this code to } \\
\text { code of awareness/advocacy } \\
\text { that empowers individuals, } \\
\text { rather advocacy and } \\
\text { awareness that comes as a } \\
\text { result of partnership. }\end{array}$ & $\begin{array}{l}\text { "We are also passionate } \\
\text { about promoting and } \\
\text { raising awareness of the } \\
\text { use of sport for positive } \\
\text { change, and we play an } \\
\text { active part in several } \\
\text { international partnership } \\
\text { networks." }\end{array}$ \\
\hline $\begin{array}{c}\text { 2. Enhanced } \\
\text { Resources- } \\
\text { Knowledge Based } \\
\text { (PS2) }\end{array}$ & & $\begin{array}{l}\text { Partnership that is based on } \\
\text { building the community's } \\
\text { knowledge base. }\end{array}$ & $\begin{array}{l}\text { This code should be used to } \\
\text { describe passages that focus on } \\
\text { partnership efforts that } \\
\text { INCREASES THE } \\
\text { COMMUNITY'S CAPACITY } \\
\text { in regards to knowledge and } \\
\text { skill base. }\end{array}$ & $\begin{array}{l}\text { This code is ONLY for } \\
\text { passages that focus on } \\
\text { partnership with outside } \\
\text { organizations to increase this } \\
\text { knowledge. }\end{array}$ & $\begin{array}{l}\text { "WhizzKids United starts } \\
\text { off by our team coming } \\
\text { into an agreement with a } \\
\text { school to implement our } \\
\text { interactive version of life } \\
\text { skills orientation for } \\
\text { students." }\end{array}$ \\
\hline $\begin{array}{l}\text { 3. Enhanced } \\
\text { Resources- Material } \\
\text { Based } \\
\text { (PS3) }\end{array}$ & & $\begin{array}{l}\text { Partnership that is based on } \\
\text { building the community's } \\
\text { access to material } \\
\text { resources, including } \\
\text { funding, needed for } \\
\text { expansion and the program }\end{array}$ & $\begin{array}{l}\text { This code should be used to } \\
\text { describe passages that focus on } \\
\text { partnership efforts that } \\
\text { increase the community's } \\
\text { capacity in regards to } \\
\text { monetary sources and } \\
\text { physical materials }\end{array}$ & $\begin{array}{l}\text { This code is ONLY for the } \\
\text { passages describing material } \\
\text { benefit of partnerships. }\end{array}$ & \\
\hline $\begin{array}{l}\text { 4. Enhanced } \\
\text { Resources- Power } \\
\text { Based } \\
\text { (PS4) }\end{array}$ & & $\begin{array}{l}\text { Partnership that is based on } \\
\text { building the community's } \\
\text { access to need political and } \\
\text { social power to make } \\
\text { lasting change }\end{array}$ & $\begin{array}{l}\text { This code should be used on } \\
\text { passages that focus on } \\
\text { partnership efforts that } \\
\text { expand political connections } \\
\text { or possibilities that allow }\end{array}$ & $\begin{array}{l}\text { This code is ONLY for use } \\
\text { on political and social } \\
\text { networking that allows more } \\
\text { access to power. }\end{array}$ & $\begin{array}{l}\text { "The United Health } \\
\text { Academy model presents } \\
\text { an exciting opportunity for } \\
\text { cooperation between } \\
\text { Africaid and government }\end{array}$ \\
\hline
\end{tabular}




\begin{tabular}{|c|c|c|c|c|}
\hline & & $\begin{array}{l}\text { access to greater political } \\
\text { power. }\end{array}$ & & $\begin{array}{l}\text { health structures. This } \\
\text { partnership will allow for } \\
\text { capacity building to } \\
\text { develop a cooperative } \\
\text { relationship between the } \\
\text { clinic and schools." }\end{array}$ \\
\hline $\begin{array}{l}\text { 5. Plans for Growth } \\
\text { and Sustainability } \\
\text { (PS5) }\end{array}$ & $\begin{array}{l}\text { Programs and measures to } \\
\text { address issues are only as } \\
\text { good as their ability to be } \\
\text { sustained and grow. }\end{array}$ & $\begin{array}{l}\text { This code should be used for } \\
\text { any passage that focuses on } \\
\text { plans of SUSTAINABILITY } \\
\text { and how partnership will help } \\
\text { enhance the ability to sustain } \\
\text { efforts as well as allow them to } \\
\text { GROW. This should be the } \\
\text { primary code that is used for } \\
\text { any sustainability measures, as } \\
\text { they are usually tied to } \\
\text { community growth. }\end{array}$ & $\begin{array}{l}\text { Do NOT use this code for } \\
\text { sustainability that speaks } \\
\text { about building local } \\
\text { ownership of the program } \\
\text { (local leaders etc.) as this } \\
\text { falls under building the } \\
\text { community capacity and } \\
\text { may or may not have to do } \\
\text { with partners' roles. }\end{array}$ & $\begin{array}{l}\text { "MYSA's rock solid } \\
\text { model has attracted the } \\
\text { interest of FIFA and } \\
\text { Nike's CSR programs." }\end{array}$ \\
\hline $\begin{array}{l}\text { 6. Role of SFW and } \\
\text { FIFA } \\
\text { (PS6) }\end{array}$ & $\begin{array}{l}\text { Partnership with SFW and } \\
\text { FIFA may offer all of the } \\
\text { above subcodes, but shows } \\
\text { that organization is willing } \\
\text { to connect with private } \\
\text { companies as well as } \\
\text { nonprofit networks }\end{array}$ & $\begin{array}{l}\text { This code should be used for } \\
\text { any passage that mentions } \\
\text { partnership between SFW and } \\
\text { FIFA, regardless of whether the } \\
\text { code can fall in another } \\
\text { partnership category. }\end{array}$ & & $\begin{array}{l}\text { "The development is part } \\
\text { of the } 20 \text { Centres for } 2010 \text {, } \\
\text { the official legacy } \\
\text { campaign of the } 2010 \\
\text { World Cup in South Africa } \\
\text { and will include } \\
\text { classrooms, a health clinic, } \\
\text { office space and an } \\
\text { Astroturf football pitch." }\end{array}$ \\
\hline
\end{tabular}

